\title{
Targeting Bacillosamine Biosynthesis in Bacterial Pathogens: Development of Inhibitors to a Bacterial Amino-Sugar Acetyltransferase from Campylobacter jejuni*
}

\author{
Joris W. De Schutter ${ }^{1}$, James P. Morrison ${ }^{1}$, Michael J. Morrison ${ }^{1}$, Alessio Ciulli ${ }^{2}$, and \\ Barbara Imperiali ${ }^{1,3, *}$ \\ ${ }^{1}$ Department of Chemistry, Massachusetts Institute of Technology, 77 Massachusetts Ave., \\ Cambridge, MA 02139, USA 2Division of Biological Chemistry and Drug Discovery, School of Life \\ Sciences, University of Dundee, Dundee, Scotland ${ }^{3}$ Department of Biology, Massachusetts \\ Institute of Technology, 77 Massachusetts Ave., Cambridge, MA 02139, USA
}

\section{Abstract \\ The glycoproteins of selected microbial pathogens often include highly modified carbohydrates such as 2,4-diacetamidobacillosamine (diNAcBac). These glycoconjugates are involved in host cell interactions and may be associated with the virulence of medically-significant Gram-negative bacteria. In light of genetic studies demonstrating the attenuated virulence of bacterial strains in which modified carbohydrate biosynthesis enzymes have been knocked out, we are developing small molecule inhibitors of selected enzymes as tools to evaluate whether such compounds modulate virulence.}

We performed fragment-based and high-throughput screens against an amino-sugar acetyltransferase enzyme, PglD, involved in biosynthesis of UDP-diNAcBac in $C$. jejuni. Herein we report optimization of the hits into potent small molecule inhibitors $\left(\mathrm{IC}_{50}<300 \mathrm{nM}\right)$. Biophysical characterization shows that the best inhibitors are competitive with acetyl coenzyme A and an X-ray co-crystal structure reveals that binding is biased towards occupation of the adenine sub-pocket of the AcCoA binding site by an aromatic ring.

\section{Graphical Abstract}

\footnotetext{
\$This paper is dedicated to the memory of Austin L. Travis

*To whom correspondence should be addressed: Phone: +1-617-253-1838, imper@mit.edu. Supporting Information Supporting information accompanying this paper includes NMR spectra and LC-MS chromatograms of selected inhibitors, molecular formula strings table, enzyme inhibition studies, DLS studies, and X-ray crystallography data.

PDB IDs: 5T2Y and 5TYH The atomic coordinates and experimental data will be released on the PDB upon article publication. Author Contributions

J.P.M., M.J.M. and A.C. were involved in the initial stages of the project, including enzyme expression and assay development, fragment screening and determination of the 5TYH structure, MLPCN screening and thienopyrimidinone hit validation. J.W.D. S. synthesized the thienopyrimidine series compounds, carried out biochemical and biophysical assays and determined the 5T2Y structure. J.W.D. S. and B.I. wrote the paper and all authors contributed to editing the final manuscript.

Conflict of interests

The authors declare that there is no conflict of interests
} 


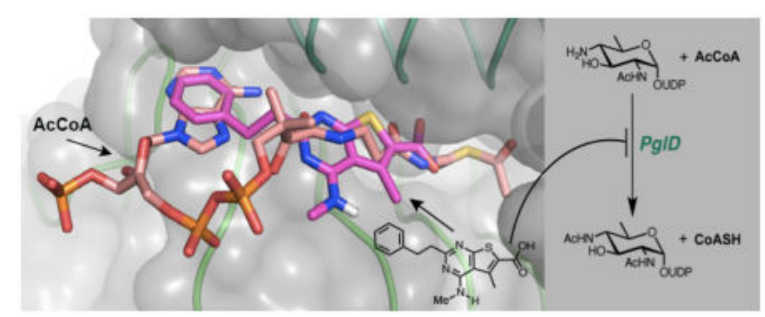

\section{Introduction}

Most clinically relevant antibiotics are targeted at essential bacterial survival functions including replication, transcription, translation, and cell wall biosynthesis. ${ }^{1}$ This is an outcome of in vitro antibiotic screening and discovery, which has relied on observing cell death in culture in laboratory settings. The emergence of resistance against all major mechanisms of antibiotic action requires new paradigms for combating infectious disease. A potentially promising approach includes the development of agents that target bacterial virulence in vivo in human hosts. Such approaches may mitigate the effects of infectious disease, while potentially resulting in less selective pressure for resistance development. ${ }^{2}$ Virulence factors are implicated in many bacterial processes including host-cell adhesion, invasion, and colonization, as well as quorum sensing and biofilm formation. ${ }^{2-5}$ In order to develop antivirulence agents, it is critical to identify validated pathogen-specific processes that cause virulence in the targeted human hosts.

Protein glycosylation is widespread in nature and regulates a variety of cellular functions including protein folding, cell-cell interactions, cell signaling, and the host immune response. ${ }^{6}$ Glycans are attached to proteins via either serine/threonine (O-linked) or the amide nitrogen of asparagine ( $\mathrm{N}$-linked). It is now recognized that selected bacteria possess the biosynthetic machinery for $\mathrm{O}-$ and/or $\mathrm{N}$-glycosylation and that this modification may play a role in pathogenicity. ${ }^{7-11} \mathrm{~N}$-glycosylation was first discovered in C. jejuni in 1999 and the protein glycosylation (pgl) pathway has been characterized in detail for this organism (Figure 1). ${ }^{12,13}$ In $C$. jejuni, more than 60 proteins, including confirmed virulence factors, are modified with a conserved heptasaccharide. ${ }^{14}$

In a significant divergence between prokaryotes and eukaryotes, bacteria and archaea have specialized enzymatic processes to modify the structures of selected carbohydrates for incorporation into glycoconjugates. Furthermore, the discovery of unique prokaryotespecific sugars is continuing with the pace of bacterial genome sequencing and bioanalytical methods development. ${ }^{7}$ In contrast to the glycosyltransferase enzymes, which assemble complex glycans and share common folds and mechanisms across domains of life, the specialized sugar-modifying enzymes are attractive targets for developing targeted antivirulence agents because they tend not to have mammalian homologs and because the associated glycoconjugates are linked with bacterial pathogenicity. ${ }^{15}$ Of particular interest is di-N-acetylbacillosamine (diNAcBac), ${ }^{16}$ which is derived from $\mathrm{N}$-acetylglucosamine (GlcNAc). DiNAcBac is found, for example, at the reducing end of O-linked glycans in selected strains of $N$. gonorrhoeae and A. baumannii, and N-linked glycans in $C$. jejuni, highlighting the importance of diNAcBac biosynthesis pathways in these Gram-negative 
pathogens. ${ }^{17}$ Intriguingly, while protein glycosylation pathways from these pathogens glycosylate diverse proteins with different glycans, the reducing-end sugar is diNAcBac. ${ }^{18-20}$ The N-linked protein glycosylation (pgl) pathway of $C$. jejuni and steps leading to diNAcBac biosynthesis are illustrated in Figure 1. The first two steps of UDPdiNAcBac biosynthesis utilize an $\mathrm{NAD}^{+}$-dependent dehydratase $(\mathrm{PgIF})$ followed by a pyridoxal phosphate-dependent aminotransferase (PglE) to produce a UDP-4-amino-sugar, which is then acetylated by PglD using acetyl coenzyme A (AcCoA) as a co-substrate (Figure 1 inset). ${ }^{18}$ Subsequent glycan assembly onto an undecaprenyl-diphosphate carrier, is catalyzed by a series of glycosyl transferases. After assembly, the completed heptasaccharide is translocated across the inner membrane and the glycan is transferred to protein substrates in the bacterial periplasm by the oligosaccharyl transferase PglB.

Studies have shown that disruption of genes responsible for diNAcBac biosynthesis ( $p g l F$, $p g I E, p g I D$ ) perturb production of the native heptasaccharide glycosyl donor in $C$. jejuni. ${ }^{21}$ In addition, $\Delta p g I D$ and $\triangle p g I E$ strains show greatly reduced colonization of the gastrointestinal tract of 1-day-old chicks, thereby establishing a link between protein $\mathrm{N}$ glycosylation and $C$. jejuni pathogenicity in host cells. ${ }^{22}$ Further insight into these effects came from transposon mutagenesis experiments, which identified $p g l F$ and $p g l E$ as essential genes for colonization. In mice, mutation of $p g I E$ impaired invasion of intestinal epithelial cells and colonization of the gut. ${ }^{23}$ The causative glycoconjugates underpinning these findings remain unknown, but several molecular associations between $\mathrm{N}$-glycosylation and C. jejuni virulence have been defined. For example, VirB10, a structural component to the type IV secretion system (TFSS), needs to be glycosylated at Asn97, otherwise a 10-fold decrease in natural competency results. ${ }^{24}$ Recently, $16 \mathrm{~N}$-linked glycoproteins were identified and found to be associated with $C$. jejuni outer membrane vesicles (OMVs) including the PEB3 adhesin. ${ }^{25}$ Pathogens deploy OMVs to deliver bacterial proteins into host cells, making this an important finding in the relationship between periplasmic glycoproteins and virulence. ${ }^{26}$ Protein O-glycosylation is also associated with virulence; for example, loss of glycosylation of PilE, a constituent of the type IV pilin in N. gonorrhoeae, leads to a significant decrease in epithelial cell adhesion. ${ }^{27}$

Herein we report the development of inhibitors targeting the $C$. jejuni PgID, a UDP-aminosugar acetyltransferase, which catalyzes the third step in diNAcBac biosynthesis. PglD represents an attractive target for inhibitor development as it is well understood from a structural and mechanistic perspective. ${ }^{28,29}$ Additionally, PglD is a soluble, well-expressed enzyme, which makes it tractable for structure/activity-driven inhibitor discovery. Crystallographic analysis of PglD reveals a homotrimeric structure with three equivalent active sites formed at the interfaces between adjacent protomers. ${ }^{28,29}$ Like many other bacterial UDP-amino-sugar acetyltransferases, PglD is a member of the left-handed $\beta$-helix family comprising two domains (Figure $2 a$ ); a N-terminal domain with a $\beta$ - $a-\beta-\alpha-\beta-\alpha$ Rossmann fold motif that binds the UDP-4-amino-sugar, and a C-terminal hexapeptide repeat motif that defines the left-handed $\beta$-helix that contributes to the AcCoA binding site. PglD has been co-crystallized in the presence of the AcCoA and UDP-4-amino-sugar substrates (Figure $2 \mathrm{~b}$ ). ${ }^{28}$ The structural features of PglD and related homologs differentiate these prokaryotic AcCoA-dependent acetyltransferases from their mammalian counterparts, 
including for example HAT1 of the GCN5-related N-acetyltransferase (GNAT) superfamily. ${ }^{30}$

Currently, many questions remain as to why modified carbohydrates, such as diNAcBac, are incorporated into bacterial glycoconjugates. Therefore, chemical tools such as small molecule inhibitors that selectively block diNAcBac biosynthesis would be valuable agents for understanding the significance of glycan diversification in selected bacteria. In addition, such tools could help to validate the pgl pathway enzymes as potential antivirulence targets. Consequently, we have established a program to develop inhibitors of diNAcBac biosynthesis with a focus on the well-characterized $C$. jejuni pathway. This Gram-negative pathogen is a common cause of gastroenteritis in humans and may also result in the development of Guillain-Barré syndrome, an auto-immune disease in which the peripheral nerves are attacked resulting in damage to the myelin insulation. ${ }^{31,32}$ In recent years, $C$. jejuni has shown increased resistance towards front-line antibiotics including the macrolides and fluoroquinolones, which inhibit protein synthesis and DNA unwinding, respectively. ${ }^{33}$

\section{Results}

\section{Screening}

Initial hits for the development of inhibitors for PglD were identified by employing fragment-based screening and high-throughput molecular library approaches. ${ }^{34}$ The fragment-based screen was performed with a fragment set that included a selection of the Maybridge Ro3 chemical library as described previously. ${ }^{35}$ The primary screen involved differential scanning fluorimetry (DSF) analysis against PgID to identify fragments that bind to and stabilize the natively-folded protein. Following this, hits were confirmed by NMR spectroscopy (WaterLOGSY and STD) and further validated using a UV-based biochemical assay, which measures CoASH release following acetyl transfer to the UDP-4-aminosugar. ${ }^{36}$ Using this workflow, 10 compound hits with $\mathrm{IC}_{50}$ values in the $1-10 \mathrm{mM}$ range and ligand efficiencies in the $0.29-0.32$ range were validated. For example, compound 1 (Figure 2), which was analyzed by X-ray in complex with PgID, binds to the central AcCoA binding groove occupying the pantetheine site proximal to active-site residues involved in amino-sugar activation and thioester attack (Figure 2c). Unfortunately, efforts to build upon this, and other validated fragments yielded only modest improvements in affinity. Coincident with these studies a high-throughput screen was performed in collaboration with the Broad Institute, using a Diversity-Orientated Synthesis (DOS) compound collection $(83,000)$ and the NIH Molecular Libraries Probe Production Centers Network (MLPCN) library $(276,000)$ of small molecules. ${ }^{37}$ Compounds were screened at $10 \mu \mathrm{M}$ using a PgID end-point assay monitoring the generation of CoASH from the acetyltransferase reaction. Despite the low hit rate (defined as $>20 \%$ inhibition) of $0.02 \%$ and $0.12 \%$ respectively, the screen led to the discovery of thienopyrimidinone-6-carboxylate compound $\mathbf{2}$ as a promising hit for further development. For direct comparison with the validated fragment hits, $\mathbf{2}$ was deconstructed to the core structure 3, which demonstrated a validated $\mathrm{IC}_{50}$ value of $860 \mu \mathrm{M}$ and LE of 0.31 . In light of these results and the tractability of the core towards synthetic manipulation at four points of diversification ( $\mathrm{C} 2, \mathrm{C} 4, \mathrm{C} 5$, and $\mathrm{C} 6$; Scheme 1) this compound class became the focus of our continuing medicinal chemistry efforts. 
Preliminary structure activity studies to vary substitution at $\mathrm{C} 2$ generated analog $\mathbf{4}$ as the best inhibitor with an $\mathrm{IC}_{50}$ value of $1 \mu \mathrm{M}$ (LE 0.33). However, although this compound represented a good improvement in potency, the candidate suffered from some disadvantages. Specifically, 4 features a planar structure with poor solubility properties and a metabolic liability due to the 1,3-unsubsituted indole and conjugated alkene systems.

Furthermore, $\mathbf{4}$ and related analogs showed poor long-term stability in solution. A significant effort was also made to crystallize PgID with several of the thienopyrimidinone hits, however, this proved unsuccessful. Therefore, we performed a docking study on fragment 3 to generate a computational model as a guide for future synthetic efforts aimed at eliminating the compound liabilities while improving potency. ${ }^{38}$ The thienopyrimidone-6carboxylate core was predicted to occupy a binding site overlapping with the panthetheine moiety of AcCoA, as had been previously observed in the co-crystal structure of fragment 1 (PDB 5TYH), with similar placement of the carboxylate moiety and close agreement between the positions of the furan oxygen of $\mathbf{1}$ and exocyclic oxygen of $\mathbf{2}$ (compare Figure $2 \mathrm{c}$ and $\mathrm{d}$ ). Given these observations, we exploited the computational model as a guide for the design of the next generation of analogs, which recognized the opportunity to extend the molecule both at the $\mathrm{C} 2$ position to interact with a hydrophobic region on the $\beta$-helix, and at the $\mathrm{C} 4$ position, by transitioning to the thienopyrimidine core, to further occupy the AcCoA binding groove (Scheme 1).

In order to reach cytoplasmic targets in Gram-negative pathogens, compounds may enter cells through passive diffusion or pass through the bacterial porins to reach the periplasm and then reach the cytoplasm via passive or active mechanisms. ${ }^{39,40}$ With these parameters in mind, our overall goal was to develop potent $\left(\mathrm{IC}_{50}<500 \mathrm{nM}\right.$ ) inhibitors of $C$. jejuni PglD based on the thienopyrimidine-6-carboxylate core with good ligand efficiency (LE >0.30) together with balanced physicochemical properties including cLogP values between $2-4 .{ }^{41}$

\section{Chemistry}

We developed modular synthetic routes to provide access to the target thienopyrimidine carboxylic acids with readily-modifiable substitution at the $\mathrm{C} 2$ and $\mathrm{C} 4$ positions (Schemes 2 and 3).

For modification at the C2-position (Scheme 2, Route I), the synthesis was initiated by condensation of commercially available thiophene, $\mathbf{5}$, with nitriles bearing the desired $\mathrm{R}_{2}$ substituent, under strongly acidic conditions. In most cases, the thienopyrimidone products of general structure 6, proved highly insoluble, and therefore chromatography and NMR characterization was carried out after the subsequent step. In cases where nitriles with the appropriate $\mathrm{R}_{2}$ moiety were inaccessible, an alternative approach (Route II) was employed. This route is somewhat longer and includes a Michaelis-Arbuzov reaction with triethyl phosphite and analog 6 (Core structure: $\mathrm{R}_{2}=-\mathrm{CH}_{2} \mathrm{Cl}$ ) to furnish phosphonate 8 . Subsequent Horner-Wadsworth-Emmons (HWE) olefination and hydrogenation generated thienopyrimidinones of general structure $\mathbf{9}$ with a variety of phenylethyl substituents at the C2-position.

Installation of a substituent at the C4-position of thienopyrimidines is typically accomplished by transforming the $\mathrm{C} 4$ oxygen of the thienopyrimidone into chloride or 
bromide, with $\mathrm{POCl}_{3}$ and $\mathrm{PBr}_{3}$ respectively, followed by a $\mathrm{S}_{\mathrm{N}} \mathrm{Ar}$ reaction, both performed at high temperatures. To avoid use of these harsh conditions and strong lachrymators, we instead employed a one-step, room temperature reaction modified from chemistry developed by researchers at Wyeth. ${ }^{42}$ Utilization of a sufficiently strong base, such as 1,8 diazabicyclo[5.4.0] undec-7-ene (DBU), in excess solubilized the thienopyrimidinones in acetonitrile and replacing the toxic and expensive BOP reagent for the readily available PyBOP, allowed for robust formation of the desired pyrimidines of general structure $\mathbf{1 0}$ in good yields (40-90\%). These thienopyrimidines could be isolated by column chromatography in excellent purity (>95\% homogeneity as determined by LC-MS). The final saponification of thioenopyrimidine esters represented by $\mathbf{7}$ and $\mathbf{1 0}$ was achieved in a $\mathrm{THF} / \mathrm{MeOH} / \mathrm{H}_{2} \mathrm{O}$ mixture containing $\mathrm{NaOH}$; occasionally mild heating was required to achieve complete conversion. The final inhibitors with core scaffold $\mathbf{1 1}$ were isolated by trituration as easy to handle solids.

A related thienopyrimidine isomer with general structure 16, was accessed as described in Scheme 3. In this case, the thiophene starting material $\mathbf{1 4}$ is not commercially available but could be readily prepared by the esterification of dicarboxylic acid $\mathbf{1 2}$ followed by nitration and hydrogenation. Condensation with nitriles provided thienopyrimidinones of general structure 15, which differ from the scaffold $\mathbf{1 1}$ series in the relative location of the sulfur atom and the absence of a methyl group on the thiophene ring. Installation of substituents at $\mathrm{C} 4$ and saponification were performed as described previously, to provide inhibitors with core scaffold 16.

\section{Initial SAR analysis}

All target thienopyrimidine carboxylic acids 11 and $\mathbf{1 6}$ (Figure 3) were assayed for inhibition of recombinantly-expressed and purified $C$. jejuni NCTC 11168 PglD acetyltransferase. ${ }^{18}$ The continuous assay monitors the release of CoASH using 5,5' dithiobis-(2-nitrobenzoic acid, ${ }^{36}$ and was carried out at $300 \mu \mathrm{M}$ AcCoA $\left(K_{m}\right.$ of $\left.295 \mu \mathrm{M}\right)$, and $500 \mu \mathrm{M}$ UDP-4-amino-sugar $\left(\mathrm{K}_{\mathrm{m}}\right.$ of $\left.274 \mu \mathrm{M}\right)$. $\mathrm{IC}_{50}$ values of selected compounds are summarized in Table 1. The AcCoA concentration was aligned with reported physiologic concentrations in typical Gram-negative bacteria. ${ }^{43}$

Our initial strategy was to explore the C2-and C4-substituents individually and then combine the optimal structural components from each series to capture advantageous synergistic binding effects. We observed that short aliphatic chains and saturated carbocycles at $\mathrm{C} 2$ (with $\mathrm{R}_{4}=\mathrm{Me}$ ) provided weak inhibitors with $\mathrm{IC}_{50}$ values in the $10 \mu \mathrm{M}$ to $1 \mathrm{mM}$ range (data not shown). Based on these studies we selected an unsubstituted phenylethyl moiety (Figure 3, substituent $\mathbf{d}$ ) as a favorable $\mathrm{C} 2$-substituent in terms of potency gain versus added mass (e.g. 17, $\mathrm{IC}_{50}=2.2 \mu \mathrm{M}$, LE 0.35, Table 1). However, when we explored C4substituents (with $\mathrm{R}_{2}=\mathrm{H}$ ), these analogs proved to be poor inhibitors $\left(\mathrm{IC}_{50}>500 \mu \mathrm{M}\right.$, data not shown) and SAR trends could not be well defined from the data. Accordingly, we elected to directly prepare disubstituted analogs, with $\mathrm{R}_{2}=$ phenylethyl (d), and iteratively build up the $\mathrm{R}_{4}$ substituent in terms of length, sterics and heteroatom substitution (e.g. inhibitors $\mathbf{1 8}$ 35; shorter and smaller substituents omitted for brevity). In general, only modest gains in potency could be achieved, and all the gains were at the cost of poorer ligand efficiencies. 
Ultimately, we observed that a phenylethyl moiety was also well tolerated at the C4-position of the thienopyrimidine core $\left(\mathbf{2 0}, \mathrm{R}_{2}=\mathrm{R}_{4}=\right.$ phenylethyl, $\left.\mathrm{IC}_{50}=1.4 \mu \mathrm{M}\right)$.

In order to gain a better understanding of the binding behaviour of the inhibitors, we examined the results of the phenyl scan on the $\mathrm{R}_{4}$ substituent, which positioned moieties with different characteristics (sterics, polarity and hydrogen-bonding capabilities) ortho, meta or para on the aryl ring (inhibitors 21-35). However, while we had predicted that these substitutions would either complement or clash with the protein surface resulting in a measurable difference in $\mathrm{IC}_{50}$ values, we instead observed a "flat" SAR with inhibitors exhibiting $\mathrm{IC}_{50}$ values around $0.5 \mu \mathrm{M}$ (e.g. 21-35). Indeed, only substitution with an acetamido group (33-35) elicited clear variances, with the ortho substitution being the most disfavored $\left(35, \mathrm{IC}_{50}=9.0 \mu \mathrm{M}\right)$. A potential explanation for the flat SAR could be that if the aryl group occupies the AcCoA binding groove then one edge would face the protein surface and the other would be solvent exposed, thus precluding any interaction between the moieties on the $\mathrm{R}_{4}$-aryl ring and the protein surface. This hypothesis was tested by preparing analogs bearing two moieties on the aryl ring (inhibitors 36-38), however, potency remained at $0.5 \mu \mathrm{M}$.

In light of these data, we developed two hypotheses. One potential hypothesis was that the compounds might have a different mode of action other than competitive inhibition with the AcCoA substrate. We explored this by applying several biochemical and biophysical approaches, which are presented in the next section (vide infra). The second possibility was that the inhibitor binding mode differed significantly from that predicted by the computational model; for example, either the ligands bind in a different location on the PgID protein surface or the enzyme itself undergoes a significant conformational change. We also noted that the $\mathrm{C} 2, \mathrm{C} 4$-disubstituted inhibitors were inherently quite symmetrical, with a pseudo $\mathrm{C}_{2}$ axis of rotation in the plane of the thienopyrimidine core (Figure $4 \mathrm{a}$ ). This feature might explain the flat SAR observed for the phenyl scan of the $\mathrm{R}_{4}$-substituent since the effect of any moiety on the aryl group could potentially be masked if the ligand flipped $180^{\circ}$ and positioned the $\mathrm{R}_{2}$-substituent in the AcCoA binding groove instead. To test this hypothesis, we synthesized inhibitors 49 and 50, which included the quasi-regioisomeric thienopyrimidine core $\mathbf{1 6}$ and, if the binding orientation remains true, should position the sulfur atom towards the protein surface. Indeed, these inhibitors had similar potency to their parent analogs (compare $49 \mathrm{IC}_{50}=3.9 \mu \mathrm{M}$ vs. $\mathbf{1 7} \mathrm{IC}_{50}=2.2 \mu \mathrm{M}$, and $\mathbf{5 0} \mathrm{IC}_{50}=1.4 \mu \mathrm{M}$ vs. $41 \mathrm{IC}_{50}=1.1 \mu \mathrm{M}$ ), suggesting the thienopyrimidine carboxylic core can bind in either of two orientations into the AcCoA binding groove. To further validate this hypothesis, we developed inhibitors that would be locked in a fixed conformation by introducing rigidifying elements in the alkyl linkers between the thienopyrimidine core and substituent aryl groups. Synthetically it was straightforward to add a methyl group on the second carbon of the $\mathrm{R}_{2^{-}}$ substituent and a methoxy group on the second carbon of the $\mathrm{R}_{4}$-substituent; the prerequisite starting materials were commercially available as both stereoisomers and could be easily transformed into the corresponding nitrile or amine for the modular syntheses (Figure $4 b$ ). With the four rigidified analogs we would expect to see data consistent with a matched/ mismatched phenomenon; either substituent should have an enantiomer that complements the protein surface better than the other and when combined these effects should result in 
one poor inhibitor, two moderate ones and a single preferred analog. Indeed, this was observed with compounds 51-54 (Figure $4 \mathrm{~b}$ ), albeit in a modest $\mathrm{IC}_{50}$ range. These combined results strongly suggested that the inhibitors were capable of binding to the PglD active site with either the $\mathrm{R}_{2^{-}}$, or $\mathrm{R}_{4^{-}}$-substituent in the $\mathrm{AcCoA}$ groove.

Overall, the SAR data (Figure 4) shows that while binding may be somewhat promiscuous, the $\mathrm{R}_{2}$-substituent was far more important for binding potency. This experimental observation was therefore inconsistent with our initial computational model, which had oriented this substituent over the $\beta$-helix (and quite solvent exposed) and placed the $\mathrm{R}_{4}{ }^{-}$ substituent in the AcCoA groove. These findings prompted us to investigate the binding mode in more detail, to provide a foundation for the next synthetic and biochemical efforts.

\section{Biophysical characterization and inhibitor optimization}

With the knowledge gained from SAR studies up to this point, we generated a potent $C$. jejuni PglD inhibitor, 55 (Figure 5), with an $\mathrm{IC}_{50}$ of $270 \mathrm{nM}$; however, this was at the cost of decreased ligand efficiency $(0.26)$ and a high $c \log \mathrm{P}(5.12)$. In order to further optimize the potency and physicochemical properties of these compounds, we needed to better characterize their binding characteristics. Towards this end, we employed several complementary approaches including the PgID inhibition assay with varying substrate concentrations, DSF analysis, dynamic light scattering (DLS) and X-ray crystallography.

We had first initiated inhibitor development based on modeling studies, which suggested that the thienopyrimidine carboxylate core competed with the AcCoA substrate for binding to the PglD active site. To test this experimentally, we monitored inhibition in the presence of varying concentrations of the two substrates. We observed that significantly higher concentrations of the UDP-4-amino-sugar substrate had no measurable effect on the inhibition by a representative analog of $\mathbf{1 1}$ (compound 37, supporting information Table S2). In contrast, a 2-, and 5-fold increase in AcCoA substrate concentration resulted in measured $\mathrm{IC}_{50}$ values of $0.63 \mu \mathrm{M}$ and $1.4 \mu \mathrm{M}$, respectively. These values represent a 2- and 4-fold decrease in potency and strongly suggest that the thienopyrimidine carboxylate inhibitors compete with AcCoA for binding to the PglD active site.

All of the data thus far has been based on the enzymatic inhibition assay and, despite the judicious use of detergent and BSA to prevent aggregation phenomena, ${ }^{44}$ may be prone to artefacts that obscure binding trends. We therefore employed DSF as a qualitative secondary assay to assess binding of inhibitors to the $C$. jejuni PglD. DSF employs a fluorescent dye, Sypro Orange, to report on the thermal denaturation of a protein or protein/ligand complex. ${ }^{45}$ Potent inhibitors bind to their target enzyme more strongly that weak ones, resulting in a more stable protein/ligand complex and higher measured melting temperature $\left(\mathrm{T}_{\mathrm{m}}\right)$. Therefore, the thermal stabilization $\left(\Delta \mathrm{T}_{\mathrm{m}}\right)$ of PglD can be used to provide an indirect measure of the relative binding affinity of the related family of compounds. We selected a subset of inhibitors with a range of $\mathrm{IC}_{50}$ values and structural characteristics to analyze by DSF and plotted the $\Delta \mathrm{T}_{\mathrm{m}} v s \mathrm{IC}_{50}$ values (Figure 6). The graph shows a positive correlation $\left(R^{2}=0.72\right)$ between inhibition potency and thermal stabilization over a range of $\mathrm{IC}_{50}$ values indicating that the compounds stabilize the native PgID homotrimer and that the more potent compounds, based on $\mathrm{IC}_{50}$ values, indeed stabilize PglD more effectively. 
Next, we analyzed the enzyme quaternary structure in solution by dynamic light scattering (DLS) and found the calculated hydrodynamic radius of apo PgID to be $\sim 34 \AA$, consistent with the crystal structures of trimeric PglD (supporting information Figure S1). In the presence of $\mathbf{1 0}$-fold excess of inhibitor $\mathbf{5 5}$, the measured radius was marginally larger, $\sim 36$ $\AA$, yet still consistent with the known trimeric structure. We also noted that the polydispersity index (PDI) of the PglD/55 complex (24\% PDI) was lower than apo PglD (31\% PDI), providing strong support that the inhibitor does not destabilize quaternary structure and indeed binds to the homotrimeric enzyme.

Throughout these efforts we also continued to pursue crystallization attempts to gain structural insight on representative thienopyrimidine analogs. X-ray analysis of the $C$. jejuni NCTC 11168 PglD enzyme has been successfully carried out in our group and others. ${ }^{28,29}$ Typically, the reported precipitant solutions were either high ionic strength (1.9 M ammonium sulfate) or contained acidic buffer components that were frequently observed to bind in the enzyme active site (sulfate, phosphate, citrate).$^{28,29}$ Despite numerous attempts, application of previously published protocols did not yield co-crystal structures with the current thienopyrimidine-6-carboxylate inhibitors and thus we screened for new conditions that would be more compatible with the binding of small organic molecules. Ultimately, a crystallization hit with PEG-3350 was successfully optimized to reliably produce high quality crystals. The crystals develop as hollow, hexagonal rods that fill in from one end as they mature; producing either "vase-like" or solid crystals (Figure S3). The diffraction quality did not appear to differ between a solid or hollow end of such crystals. The crystals were tolerant of DMSO in concentrations up to $10 \%$, but tended to be rather fragile and could break upon looping. Therefore, we employed an "in-drop soaking" protocol, in which a solution of the inhibitor is directly added to the drop containing the crystals.

Using these crystallization conditions, we were able to obtain high-quality diffraction data and successfully solve the co-crystal structure of the PgID/17 complex (Figure 7 and S4). From the structure, two significant observations were immediately evident. Firstly, as anticipated from the SAR studies, the thienopyrimidine core was flipped $180^{\circ}$ compared to the computational model developed with the core fragment, with the $\mathrm{R}_{2}$-subsituent binding in the AcCoA groove (Figure 7, panel b). This position of the thienopyrimidine core directs the $\mathrm{R}_{4}$-subsituent away from the AcCoA groove and into solvent where it makes no significant interactions with the PglD protein surface (Figure S5, LigPlot ${ }^{46}$ ). This observation is consistent with our SAR findings that $\mathrm{R}_{4}$-subsituent makes small contributions to inhibitor potency at the expense of ligand efficiency (Table 1). Secondly, the most surprising observation was that the ligand was bound 3.9 A further along the AcCoA groove, relocating the carboxylate distal to the acetyltransferase active site where the AcCoA thioester is normally accommodated. This observation was rather unexpected as we assumed that the Asn118, H134 and S136 residues would be preferred hydrogen-bonding partners for the inhibitor carboxylic acid moiety. Furthermore, this displacement precludes a T-shaped $\pi$-stacking between the side chain of Phe152 and the thienopyrimidine core; instead the binding mode positions Phe152 at an offset angle over the inhibitor carboxylate (Figure S4). To compensate, inhibitor 17 makes several other key interactions with the PglD surface; the carboxylic acid moiety is positioned at a favorable distance and orientation to 
form hydrogen bonds with the Ser136 side chain and the backbone amide NH of Ile155. Similarly, the thienopyrimidine N1 atom is well placed to interact with Gly173. From the structure it appears that a definitive interaction may be the placement of the $\mathrm{R}_{2}$ phenyl ring within the AcCoA adenine binding sub-pocket, displacing solvent waters from a relatively hydrophobic protein cavity. The ligand binding mode is also internally favorable (low torsion) as the bound conformation adopts an anti-periplanar angle of approximately $160^{\circ}$ along the benzylidene bond between the thienopyridimine core and $\mathrm{R}_{2}$ phenyl ring (Figure 7c).

Armed with this new structural information we set out to further optimize the inhibitor series. First we investigated the possibility of simultaneously placing the $\mathrm{R}_{2}$ phenyl ring in the adenine sub-pocket and the carboxylate in the active site hot spot by increasing the linker length between the inhibitor core and $\mathrm{R}_{2}$-substituent. This did not prove successful as analogs 39 and $\mathbf{4 0}$ (with a 3- and 4-carbon linker respectively) demonstrated lower in vitro potency; presumably due to internal strain of unfavorable torsion angles of the alkyl linker. Secondly we noted that although the $\mathrm{R}_{2}$ phenyl group fits well in the adenine sub-pocket, it does not fully occupy the volume of the [6,5]-fused ring cavity and there was unoccupied space at the meta position relative to the linker (Figure 7c). We explored several moieties at this position (41-OMe, $\mathbf{4 2}-\mathrm{F}, \mathbf{4 6}-\mathrm{Cl}$ and $\mathbf{4 7}-\mathrm{CF}_{3}$, Table 1), but only gained a minor improvement in potency with compound $\mathbf{4 1}\left(\mathrm{IC}_{50}=1.1 \mu \mathrm{M}\right)$. Finally upon closer inspection of the adenine sub-pocket we speculated that if the aromatic carbon at a position ortho to the linker is replaced by a nitrogen and protonated, it would be well-oriented to form a hydrogen bond with the backbone oxygen of Gly173, as it does with the exocyclic amine of the adenine of the AcCoA substrate (PDB ID 3BSY). ${ }^{28}$ While the resultant pyridine nitrogen is only weakly basic, it could potentially be protonated in the microenvironment of the enzyme and lead to an order of magnitude improvement in potency. For example, the pyridine derivative risedronic acid is a $\sim 300$-fold more potent inhibitor of the human farnesyl pyrophosphate synthase than the corresponding phenyl analog. ${ }^{47}$ Although not as significant, the 4.8-fold fold enhancement we observed between inhibitor $\mathbf{4 3}\left(\mathrm{IC}_{50}=0.46\right.$ $\mu \mathrm{M})$ and $\mathbf{1 7}\left(\mathrm{IC}_{50}=2.2 \mu \mathrm{M}\right)$ is very interesting considering the minor nature of the structural change. Although $\mathbf{4 3}$ is not the most potent inhibitor, it exhibits the best ligand efficiency, 0.39 , and has a $\operatorname{cog} \mathrm{P}$ of 2.94 , within the $-0.5-3$ range that is thought to be ideal to reach cytoplasmic targets of Gram-negative bacteria; with these characteristics $\mathbf{4 3}$ represents our best candidate to date with balanced physicochemical properties.

\section{Discussion and Conclusions}

In the development of inhibitors of the $C$. jejuni UDP-4-amino-sugar acetyltransferase, PglD, we initially screened both fragment-based and HTS libraries. These studies led to the identification of a thienopyrimidine-6-carboxylate core as a promising hit. Over the course of the SAR studies we found substitution at the C2-position of the core to be most impactful and that the binding mode appeared to be poorly predicted in silico. By combining data from substrate competition assays, DSF, and DLS we confirmed that the inhibitors bind exclusively to the AcCoA binding groove of the active site without disrupting the homotrimeric structure of PglD. 
Critically, crystallographic analysis reveals a $180^{\circ}$ flip of the thienopyrimidine core to place the $\mathrm{R}_{2}$-substituent in the AcCoA groove, as was anticipated from the SAR data. However, in contrast to previously characterized small fragments, we observed a $3.9 \AA$ displacement of the inhibitor further along the AcCoA groove away from the known thioester binding site. Notably, in this new binding mode, the inhibitor makes several hydrogen-bonding interactions that compensate for the ones that would have been formed with the key catalytic residues (Asn118 \& His134), but also precludes a stabilizing T-shaped $\pi$-interaction between the thienopyrimidine core and Phe152. Ultimately, it appears that placement of the $\mathrm{R}_{2}$-phenyl into the adenine sub-pocket of AcCoA binding site may be the main driving force of ligand binding and indeed further optimization of this interaction resulted in to our most promising lead. Specifically, inhibitor $\mathbf{4 3}\left(\mathrm{IC}_{50}=0.46 \mu \mathrm{M}\right)$ shows an excellent ligand efficiency of 0.39 and a favorable clogP of 2.94 . To the best of our knowledge this is the first competitive inhibitor with an $\mathrm{IC}_{50}$ value $<1 \mu \mathrm{M}$ for a bacterial amino-sugar-modifying enzyme. A selection of inhibitors from the series presented herein was also tested against the structurally homologous amino-sugar acetyltransferase from $N$. gonorrhoeae (PglC in that O-linked glycosylation pathway) and no significant inhibition was observed even at $100 \mu \mathrm{M}$. This observation was not surprising considering the significant differences between the AcCoA binding sites of the two enzymes. ${ }^{48}$

With respect to biological analysis, the in vivo analysis of inhibitors that target bacterial virulence factors requires more complex experimental approaches than the simple estimation of minimal inhibitory concentrations (MICs) used in assessing bacterial viability with antibiotics that are targeted at cell survival processes. We are therefore pursuing multiple strategies to investigate in vivo efficacy both directly in $C$. jejuni, by assessing the impact of the inhibitors on glycoprotein biosynthesis, and in cell culture models of mammalian gut endothelia assessing $C$. jejuni adhesion and invasion. Currently, despite robust in vitro activity, we do not observe a reduction in glycosylation of periplasmic and cell surface proteins upon treatment of $C$. jejuni with the current inhibitors. This observation may be the result of insufficient inhibition potency against the target and/or may result from limited cellular uptake or efflux. In this context, $C$. jejuni features both a formidable cell wall including inner and outer cell membranes flanking a peptidoglycan barrier together with a dense external glycocalyx, as well as an active CmeABC efflux pump system to guard against external chemical agents. ${ }^{49}$ With respect to potency, the X-ray analysis of PglD with compound $\mathbf{1 7}$ provides an excellent foundation for further structure-guided optimization of the thienopyrimidine core. Concerning cellular uptake and efflux, which are common impediments to antibiotic activity in Gram-negative pathogens, the presented thienopyrimidine core also offers considerable opportunities. In particular, we are exploring several strategies including bioisosteric replacement of the carboxylate moiety and development of pro-drug analogs in consideration of the fact that the negative charge of the carboxylic acid moiety might acting as an impediment for compound uptake into the cytoplasm, which is the site of PgID activity. Additionally, the C4-substituent of the thienopyrimidine series represents a valuable handle for modulating the cLogP of the inhibitor, since we have demonstrated that substitution at this site can be varied without adversely perturbing PgID inhibition. As elegantly demonstrated in a recent study of another Gram-negative pathogen, researchers have shown that fine-tuning the physical properties of 
inhibitors, in this case to mimic the zwitterionic charge distribution of amino acids, allowed novel carbapenem analogs to pass through the OccD1 membrane porin of $P$. aeruginosa. ${ }^{50}$ Thus the thienopyrimidine compounds in this report are amenable to further such optimizations and current efforts are focused on overcoming the $C$. jejuni defenses to validate PgID as a potential antivirulence target in the biological context of infection.

Overall the studies presented herein support further development of small molecule inhibitors as tools for investigating of the role diNAcBac in bacterial glycosylation and how it relates to pathogenicity. Promising candidates targeting important virulence factors have already been documented, including agents inhibiting pilus assembly in uropathogenic $E$. $\operatorname{colr}^{51}$ and bacterial motility by inhibiting disulfide formation of periplasmic proteins. ${ }^{52}$ Progress has also been made towards modulators of quorum sensing..$^{53}$ Closely related to the work in this paper, the Sulea and Logan research groups have reported an inhibitor that targets the pseudaminic acid biosynthetic pathway found in H. pylori and C. jejuni. ${ }^{54}$ The "sialic-acid like" nonulosonate sugar product is required for the glycosylation of structural flagellin proteins and exposure to inhibitors attenuated flagellin production at concentrations of $\geq 100 \mu \mathrm{M}$. The flagella are required for persistent infections of $H$. pylori and this work demonstrates the link between bacterial glycosylation and pathogenicity using chemical tools (as opposed to genetic modification). The most advanced antivirulence work has been accomplished with N-phenyl-4-(3-phenylthioureido)benzenesulfonamide, 56 (LED209), a prodrug agent that covalently inhibits $\mathrm{QseC}$, a receptor involved in signaling between many Gram-negative pathogens and the infected host. ${ }^{55}$ Treatment with $\mathbf{5 6}$ in a mouse infection model showed prophylactic efficacy against $S$. typhimurium and provided protection against F. tularensis both pre- and post-infection. Furthermore, $\mathbf{5 6}$ was not toxic at therapeutic doses and did not affect pathogen growth in vitro. These promising in vivo results are compelling evidence that killing is not necessarily required for treatment of bacterial infection and alternate therapeutic intervention strategies are worth exploring.

In conclusion, herein we disclose the hit-to-lead development of a new series of thienopyrimidine-6-carboxylate inhibitors of the $C$. jejuni PgID UDP-amino-sugar acetyltransferase enzyme, which, upon further optimization could represent valuable chemical tools for unraveling the intricate biological role(s) of highly modified sugars in bacteria and potentially may lead to new agents with targeted antivirulence activity.

\section{Experimental section}

\section{General Procedures for Characterization of Compounds}

All intermediate compounds were purified by normal phase flash column chromatography on silica gel using a CombiFlash instrument. The homogeneity of all final compounds was confirmed to $\searrow 95 \%$ by analytical reverse-phase LC-MS using an Agilent Series 1100 HPLC instrument equipped with a YMC AQ12S03-1003WT C18 column and a Finnigan LCQ Deca electrospray ionization mass spectrometer, using a gradient of 5-95\% in $20 \mathrm{~min}$ of acetonitrile in water with $0.1 \%$ TFA. Each final compound was fully characterized by ${ }^{1} \mathrm{H}$ and ${ }^{13} \mathrm{C}$ NMR and HRMS. Chemical shifts $(\delta)$ are reported in ppm relative to the internal deuterated solvent $\left({ }^{1} \mathrm{H},{ }^{13} \mathrm{C}\right)$, unless indicated otherwise. The high-resolution MS spectra of final products were recorded using direct analysis in real time (DART) ionization on a 
Bruker Daltonics APEXIV 4.7 Tesla Fourier Transform Ion Cyclotron Resonance Mass Spectrometer (FT-ICR-MS).

\section{General procedure for the formation of thienopyrimidinones - Parent structure 6}

A pressure vessel washed charged with aminothiophene (1 equivalent) and nitrile (1-1.2 equivalents) and $4 \mathrm{M} \mathrm{HCl}$ in dioxane was added via syringe. The pressure vessel was tightly sealed with a Teflon screw cap stopper and the reaction was stirred at $80^{\circ} \mathrm{C}$ until the reaction was complete, as judged by TLC. The reaction mixture was cooled to room temperature, transferred to an Erlenmeyer flask in an ice-bath with a minimum volume of methanol and diluted with water (10-fold of solvent volume). The $\mathrm{pH}$ was brought to $\sim 8$ with ammonium hydroxide solution (25\%) resulting in precipitate formation. The mixture was held on ice for 15-60 min and then filtered over filter paper; washing with distilled water. The residue was dried under vacuum to afford the desired thienopyrimidine in sufficient purity for the subsequent step. Due to the poor solubility of these compounds, full characterization was performed after the next synthetic step and purification.

\section{Ethyl 2-((diethoxyphosphoryl)methyl)-5-methyl-4-oxo-3,4-dihydrothieno[2,3-d]pyrimidine-6- carboxylate (8)}

A $100 \mathrm{~mL}$ RBF was charged with ethyl 2-(chloromethyl)-5-methyl-4-oxo-3,4dihydrothieno[2,3-d]pyrimidine-6-carboxylate $(900 \mathrm{mg}, 3.13 \mathrm{mmol})(\mathbf{6})$ and triethylphosphite $(10.4 \mathrm{~g}, 10.8 \mathrm{~mL}, 62.8 \mathrm{mmol})$ was added via syringe and the reaction was heated at $145^{\circ} \mathrm{C}$ for $2 \mathrm{~h}$. The reaction mixture was cooled down, diluted with $100 \mathrm{~mL}$ diethyl ether and stirred for $1 \mathrm{~h}$ on ice. The suspension was filtered, washed with copious amounts of ether and petroleum ether. The obtained residue was dried on high vacuum to furnish the desired the product as a fine, free-flowing white powder, $994 \mathrm{mg}(82 \%) .{ }^{1} \mathrm{H}$ NMR (500 MHz, DMSO) $\delta 12.62$ (s, NH), 4.28 (q, $J=7.1 \mathrm{~Hz}, 2 \mathrm{H}), 4.10-3.99(\mathrm{~m}, 4 \mathrm{H})$, 3.37 (d, $J=22.2 \mathrm{~Hz}, 2 \mathrm{H}), 2.79(\mathrm{~s}, 3 \mathrm{H}), 1.28(\mathrm{t}, J=7.1 \mathrm{~Hz}, 3 \mathrm{H}), 1.21(\mathrm{t}, J=7.0 \mathrm{~Hz}, 6 \mathrm{H}) .{ }^{13} \mathrm{C}$ NMR (126 MHz, DMSO) $\delta 166.99$ (d, $J=3.0 \mathrm{~Hz}), 162.98,159.97,154.77(\mathrm{~d}, J=8.6 \mathrm{~Hz})$, 144.46, 122.93, 122.17, 63.42 (d, $J=6.3 \mathrm{~Hz}), 62.28,33.99$ (d, $J=131.2 \mathrm{~Hz}), 17.30$ (d, $J=$ $6.0 \mathrm{~Hz}), 15.95,15.29 .{ }^{31} \mathrm{P}$ NMR (121 MHz, DMSO) $\delta$ 21.87. MS (ESI): calcd. 389.09; found $389.07[\mathrm{M}+\mathrm{H}]^{+}$.

\section{General procedure for the Horner-Wadsworth-Emmons reactions}

To an ice-cooled solution of phosphonate $\mathbf{8}$ ( 1 equivalent) and aldehyde ( 3 equivalents) in anhydrous THF was added sodium hydride (60\% suspension in mineral oil, 3 equivalents) in small portions. The reaction was stirred at RT until complete consumption of starting material, as determined by TLC. The crude product was poured into ice-water ( 5 times the reaction solvent volume), filtered and washed with water. The filter-cake was washed with ice-cold ethanol, diethyl ether and pentanes. The residue was dried on high vacuum to furnish the desired product in sufficient purity for subsequent reactions.

\section{General procedure for the hydrogenation reactions}

A round bottom flask was charged with the alkene product from the HWE reaction, suspended in $\mathrm{MeOH} / \mathrm{THF} / \mathrm{NH}_{4} \mathrm{OH}$ 10:2:1 and purged with nitrogen. Pearlman's catalyst was 
added $\left(20 \% \mathrm{Pd}(\mathrm{OH})_{2} / \mathrm{C}, 0.5\right.$ equivalents, $\left.\mathrm{CAS} 12135-22-7\right)$, and the reaction mixture was purged with $\mathrm{H}_{2}$ gas and equipped with an $\mathrm{H}_{2}$-filled balloon. The reaction was stirred at $60^{\circ} \mathrm{C}$ until complete consumption of starting material, as determined by TLC, replenishing the $\mathrm{H}_{2}$ balloon as needed. The reaction mixture was purged with nitrogen and filtered through a plug of Celite, rinsing with EtOAc. The filtrate was concentrated in vacuo and the obtained material was used without further purification.

\section{General procedure for the formation of ester precursors (10)}

To a solution of or thienopyrimidinone (1 equivalent) and (benzotriazol-1-yloxy)tripyrrolidinophosphonium hexafluorophosphate (PyBOP, 1.3 equivalents) in anhydrous acetonitrile was added 1,8-diazabicyclo[5.4.0] undec-7-ene (1.5 equivalents, 3 equivalents in case of amine- $\mathrm{HCl}$ salts) via syringe. The mixture was stirred at $\mathrm{RT}$ for $5 \mathrm{~min}$, after which the nucleophile (1.5 equivalents) was added and the reaction stirred at RT until complete consumption of starting material, as determined by TLC. The solvent was removed in vacuo and the crude residue was purified by column chromatography on silica gel using a gradient of EtOAc in 1:1 Hex $/ \mathrm{CH}_{2} \mathrm{Cl}_{2}$. Note: Substituent b was introduced as a mono-Boc-protected diamine; the Boc protecting group was expediently removed by treating the compound with $4 \mathrm{M} \mathrm{HCl}$ in 1,4-dioxane followed by precipitation with cold diethyl ether and filtration.

\section{Ethyl 5-methyl-4-(methylamino)-2-phenethylthieno[2,3-d]pyrimidine-6-carboxylate 10(d,a)}

Isolated $80 \mathrm{mg}$ (77\% yield) as a white solid. ${ }^{1} \mathrm{H}$ NMR (500 MHz, DMSO) $\delta 7.27-7.19(\mathrm{~m}$, 4H), $7.17-7.12(\mathrm{~m}, 1 \mathrm{H}), 7.09(\mathrm{~m}, \mathrm{NH}), 4.28(\mathrm{q}, J=7.1 \mathrm{~Hz}, 2 \mathrm{H}), 3.09-3.04(\mathrm{~m}, 2 \mathrm{H}), 3.02$ $-2.97(\mathrm{~m}, 5 \mathrm{H}), 2.86(\mathrm{~s}, 3 \mathrm{H}), 1.28(\mathrm{t}, J=7.1 \mathrm{~Hz}, 3 \mathrm{H}) .{ }^{13} \mathrm{C}$ NMR $(126 \mathrm{MHz}, \mathrm{DMSO}) \delta$ $168.26,167.97,163.50,159.84,142.72,141.08,129.47,129.39,126.92,120.08,115.95$, 62.16, 41.31, 34.42, 29.27, 16.74, 15.34. MS (ESI): calcd. 356.14; found $356.27[\mathrm{M}+\mathrm{H}]^{+}$.

\section{Ethyl 4-((2-aminoethyl)amino)-5-methyl-2-phenethylthieno[2,3-d]pyrimidine-6-carboxylate 10(d,b)}

Isolated $70 \mathrm{mg}$ (92\% yield) as a white powder. ${ }^{1} \mathrm{H}$ NMR (500 MHz, DMSO) $\delta 8.00$ (br. s., $\left.\mathrm{NH}_{2}\right), 7.48(\mathrm{~m}, \mathrm{NH}), 7.29-7.24(\mathrm{~m}, 4 \mathrm{H}), 7.19-7.14(\mathrm{~m}, 1 \mathrm{H}), 4.30(\mathrm{q}, J=7.1 \mathrm{~Hz}, 2 \mathrm{H}), 3.81$ $(\mathrm{q}, J=5.6 \mathrm{~Hz}, 2 \mathrm{H}), 3.12-3.03(\mathrm{~m}, 6 \mathrm{H}), 2.95(\mathrm{~s}, 3 \mathrm{H}), 1.30(\mathrm{t}, J=7.1 \mathrm{~Hz}, 3 \mathrm{H}) .{ }^{13} \mathrm{C}$ NMR $(75$ MHz, DMSO) $\delta 165.02,162.48,159.04,141.38,140.89,129.04,128.98,126.75,121.53$, $116.43,62.15,38.60,38.41,33.27,16.21,14.79$. MS (ESI): calcd. 385.170 ; found 385.20 $[\mathrm{M}+\mathrm{H}]^{+}$.

\section{Ethyl 4-(benzylamino)-5-methyl-2-phenethylthieno[2,3-d]pyrimidine-6-carboxylate 10(d,c)}

Isolated $80 \mathrm{mg}$ (79\% yield) as an off-white solid. ${ }^{1} \mathrm{H}$ NMR (500 MHz, DMSO) $\delta 7.70(\mathrm{~m}$, $\left.\mathrm{NH}_{2}\right), 7.40(\mathrm{~d}, J=7.7 \mathrm{~Hz}, 2 \mathrm{H}), 7.29(\mathrm{t}, J=7.6 \mathrm{~Hz}, 2 \mathrm{H}), 7.23-7.15(\mathrm{~m}, 3 \mathrm{H}), 7.09(\mathrm{~m}, 3 \mathrm{H})$, $4.75(\mathrm{~d}, J=5.8 \mathrm{~Hz}, 2 \mathrm{H}), 4.27(\mathrm{q}, J=7.1 \mathrm{~Hz}, 2 \mathrm{H}), 2.93(\mathrm{~m}, 7 \mathrm{H}), 1.28(\mathrm{t}, J=7.1 \mathrm{~Hz}, 3 \mathrm{H}) .{ }^{13} \mathrm{C}$ NMR (126 MHz, DMSO) $\delta 168.26,168.09,163.46,159.24,142.59,141.04,140.88,129.38$, 129.33, 128.52, 127.77, 126.85, 120.39, 115.86, 62.19, 45.07, 41.25, 34.27, 16.88, 15.31. MS (ESI): calcd. 432.17; found $432.33[\mathrm{M}+\mathrm{H}]^{+}$. 


\section{Ethyl 5-methyl-2-phenethyl-4-(phenethylamino)thieno[2,3-d]pyrimidine-6-carboxylate 10(d,d)}

Isolated $106 \mathrm{mg}$ (91\% yield) as a pale yellow solid. ${ }^{1} \mathrm{H}$ NMR (500 MHz, DMSO) $\delta 7.32-$ $7.16(\mathrm{~m}, 8 \mathrm{H} \& \mathrm{NH}), 7.16-7.07(\mathrm{~m}, 2 \mathrm{H}), 4.26(\mathrm{q}, J=7.0 \mathrm{~Hz}, 2 \mathrm{H}), 3.72(\mathrm{dd}, J=14.0,6.3$ $\mathrm{Hz}, 2 \mathrm{H}), 3.13-3.05(\mathrm{~m}, 2 \mathrm{H}), 3.05-2.96(\mathrm{~m}, 2 \mathrm{H}), 2.94-2.86(\mathrm{~m}, 2 \mathrm{H}), 2.79(\mathrm{~s}, 3 \mathrm{H}), 1.27(\mathrm{t}$, $J=7.1 \mathrm{~Hz}, 3 \mathrm{H}) .{ }^{13} \mathrm{C}$ NMR $(126 \mathrm{MHz}, \mathrm{DMSO}) \delta 168.22,168.19,163.44,159.23,142.67$, $140.85,140.67,129.82,129.55,129.40,129.37,127.29,126.93,120.27,115.77,62.14$, $43.49,41.29,35.77,34.47,16.60,15.30$. MS (ESI): calcd. 446.19; found $446.40[\mathrm{M}+\mathrm{H}]^{+}$.

\section{Ethyl 4-((4-methoxyphenethyl)amino)-5-methyl-2-phenethylthieno[2,3-d]pyrimidine-6- carboxylate $10(\mathrm{~d}, \mathrm{~g})$}

Isolated $172 \mathrm{mg}$ (83\% yield) as an off-white solid. ${ }^{1} \mathrm{H}$ NMR (500 MHz, DMSO) $\delta 7.26-$ $7.20(\mathrm{~m}, 4 \mathrm{H}), 7.18-7.09$ (m, 3H \& NH), 6.86 (d, $J=8.6 \mathrm{~Hz}, 2 \mathrm{H}), 4.28$ (q, $J=7.1 \mathrm{~Hz}, 2 \mathrm{H})$, $3.71-3.66(\mathrm{~m}, 5 \mathrm{H}), 3.12-3.07(\mathrm{~m}, 2 \mathrm{H}), 3.03-2.99(\mathrm{~m}, 2 \mathrm{H}), 2.86-2.80(\mathrm{~m}, 5 \mathrm{H}), 1.28(\mathrm{t}, J$ $=7.1 \mathrm{~Hz}, 3 \mathrm{H}) .{ }^{13} \mathrm{C} \mathrm{NMR}\left(75 \mathrm{MHz}, \mathrm{CDCl}_{3}\right) \delta 168.07,163.30,158.99,158.70,142.08$, $138.32,130.92,130.03,128.70,128.55,126.07,121.47,115.33,114.46,61.45,55.53$, 42.47, 41.16, 34.55, 34.46, 15.70, 14.58. MS (ESI): calcd. 476.20; found $476.40[\mathrm{M}+\mathrm{H}]^{+}$.

\section{Ethyl 4-((3-methoxyphenethyl)amino)-5-methyl-2-phenethylthieno[2,3-d]pyrimidine-6- carboxylate 10(d,h)}

Isolated $182 \mathrm{mg}$ (87\% yield) as a pale yellow solid. ${ }^{1} \mathrm{H}$ NMR (500 MHz, DMSO) $\delta 7.27-$ $7.19(\mathrm{~m}, 6 \mathrm{H}), 7.17-7.11(\mathrm{~m}, 1 \mathrm{H} 7 \mathrm{NH}), 6.82(\mathrm{~m}, 2 \mathrm{H}), 4.28(\mathrm{q}, J=7.1 \mathrm{~Hz}, 2 \mathrm{H}), 3.73(\mathrm{~m}$, $2 \mathrm{H}), 3.69(\mathrm{~s}, 3 \mathrm{H}), 3.10(\mathrm{~m}, 2 \mathrm{H}), 3.01(\mathrm{~m}, 2 \mathrm{H}), 2.91-2.86(\mathrm{~m}, 2 \mathrm{H}), 2.82(\mathrm{~s}, 3 \mathrm{H}), 1.28(\mathrm{t}, J=$ $7.1 \mathrm{~Hz}, 3 \mathrm{H}) .{ }^{13} \mathrm{C}$ NMR $\left(75 \mathrm{MHz}, \mathrm{CDCl}_{3}\right) \delta 168.05,163.28,160.23,158.96,142.08,140.67$, 138.35, 130.10, 128.70, 128.56, 126.08, 121.47, 121.36, 115.34, 114.92, 112.13, 61.45, 55.39, 42.27, 41.18, 35.41, 34.56, 15.66, 14.58. MS (ESI): calcd. 476.20; found 476.47 [M $+\mathrm{H}]^{+}$.

\section{Ethyl 4-((2-methoxyphenethyl)amino)-5-methyl-2-phenethylthieno[2,3-d]pyrimidine-6- carboxylate 10(d,i)}

Isolated $198 \mathrm{mg}$ (95\% yield) as a beige solid. ${ }^{1} \mathrm{H}$ NMR (500 MHz, DMSO) $\delta 7.25-7.11$ $(\mathrm{m}, 7 \mathrm{H}), 7.08(\mathrm{~m}, \mathrm{NH}), 6.95(\mathrm{~d}, J=7.6 \mathrm{~Hz}, 1 \mathrm{H}), 6.86(\mathrm{td}, J=7.4,1.0 \mathrm{~Hz}, 1 \mathrm{H}), 4.28(\mathrm{q}, J=$ $7.1 \mathrm{~Hz}, 2 \mathrm{H}), 3.74(\mathrm{~s}, 3 \mathrm{H}), 3.73-3.68(\mathrm{~m}, 2 \mathrm{H}), 3.09(\mathrm{~m}, 2 \mathrm{H}), 3.00(\mathrm{~m}, 2 \mathrm{H}), 2.92(\mathrm{t}, J=7.3$ $\mathrm{Hz}, 2 \mathrm{H}), 2.81$ (s, 3H), $1.30-1.26(\mathrm{~m}, 3 \mathrm{H}) .{ }^{13} \mathrm{C} \mathrm{NMR}\left(75 \mathrm{MHz}, \mathrm{CDCl}_{3}\right) \delta 168.04,163.38$, $159.12,157.72,142.17,138.59,130.92,128.72,128.54,128.39,127.51,126.04,121.11$, 115.32, 110.79, 61.40, 55.61, 41.84, 41.19, 34.53, 29.65, 15.62, 14.59. MS (ESI): calcd. 476.20; found $476.27[\mathrm{M}+\mathrm{H}]^{+}$.

\section{Ethyl 4-((4-fluorophenethyl)amino)-5-methyl-2-phenethylthieno[2,3-d]pyrimidine-6- carboxylate 10(d,j)}

Isolated $183 \mathrm{mg}\left(90 \%\right.$ yield) as a pale yellow solid. ${ }^{1} \mathrm{H} \mathrm{NMR}\left(300 \mathrm{MHz}, \mathrm{CDCl}_{3}\right) \delta 7.32-$ $7.23(\mathrm{~m}, 4 \mathrm{H}), 7.21-7.12(\mathrm{~m}, 3 \mathrm{H}), 7.02(\mathrm{~m}, 2 \mathrm{H}), 5.61(\mathrm{t}, J=5.5 \mathrm{~Hz}, \mathrm{NH}), 4.34(\mathrm{q}, J=7.1$ $\mathrm{Hz}, 2 \mathrm{H}), 3.85$ (dd, $J=12.5,6.8 \mathrm{~Hz}, 2 \mathrm{H}), 3.22-3.14(\mathrm{~m}, 4 \mathrm{H}), 2.94(\mathrm{~m}, 2 \mathrm{H}), 2.71(\mathrm{~s}, 3 \mathrm{H})$, $1.38(\mathrm{t}, J=7.1 \mathrm{~Hz}, 3 \mathrm{H}) .{ }^{13} \mathrm{C} \mathrm{NMR}\left(75 \mathrm{MHz}, \mathrm{CDCl}_{3}\right) \delta 168.02,163.25,161.95(\mathrm{~d}, J=245.0$ 
$\mathrm{Hz}), 158.92,142.03,138.10,134.79$ (d, $J=3.3 \mathrm{~Hz}), 130.55,130.44,128.67,128.57,126.09$, $121.68,115.82$ (d, $J=21.2 \mathrm{~Hz}), 115.30,61.49,42.44,41.14,34.63,34.54,15.71,14.57$. MS (ESI): calcd. 464.18; found $464.47[\mathrm{M}+\mathrm{H}]^{+}$.

\section{Ethyl 4-((3-fluorophenethyl)amino)-5-methyl-2-phenethylthieno[2,3-d]pyrimidine-6- carboxylate 10(d,k)}

Isolated $168 \mathrm{mg}\left(83 \%\right.$ yield) as a pale yellow solid. ${ }^{1} \mathrm{H} \mathrm{NMR}\left(300 \mathrm{MHz}, \mathrm{CDCl}_{3}\right) \delta 7.34-$ $7.23(\mathrm{~m}, 5 \mathrm{H}), 7.18(\mathrm{~m}, 1 \mathrm{H}), 7.05-6.89(\mathrm{~m}, 3 \mathrm{H}), 5.63(\mathrm{t}, J=5.4 \mathrm{~Hz}, \mathrm{NH}), 4.34(\mathrm{q}, J=7.1$ $\mathrm{Hz}, 2 \mathrm{H}), 3.87$ (dd, $J=12.5,6.8 \mathrm{~Hz}, 2 \mathrm{H}), 3.23-3.15$ (m, 4H), $2.96(\mathrm{~m}, 2 \mathrm{H}), 2.72(\mathrm{~s}, 3 \mathrm{H})$, $1.38(\mathrm{t}, J=7.1 \mathrm{~Hz}, 3 \mathrm{H}) .{ }^{13} \mathrm{C}$ NMR $\left(75 \mathrm{MHz}, \mathrm{CDCl}_{3}\right) \delta 168.01,163.27(\mathrm{~d}, J=246.3 \mathrm{~Hz})$, 163.23, 158.88, 142.02, 141.77 (d, $J=7.1 \mathrm{~Hz}), 138.14,130.49$ (d, $J=8.3 \mathrm{~Hz}), 128.68$, $128.57,126.09,124.78,124.75,121.68,115.90$ (d, $J=20.9 \mathrm{~Hz}), 115.31,113.88$ (d, $J=21.0$ $\mathrm{Hz}), 61.48,42.17,41.16,35.21,34.56,15.69$, 14.57. MS (ESI): calcd. 464.18; found 464.47 $[\mathrm{M}+\mathrm{H}]^{+}$.

\section{Ethyl 4-((2-fluorophenethyl)amino)-5-methyl-2-phenethylthieno[2,3-d]pyrimidine-6- carboxylate 10(d,I)}

Isolated $170 \mathrm{mg}$ (84\% yield) as an off-white solid. ${ }^{1} \mathrm{H} \mathrm{NMR}\left(300 \mathrm{MHz}, \mathrm{CDCl}_{3}\right) \delta 7.32$ $7.02(\mathrm{~m}, 9 \mathrm{H}), 5.69(\mathrm{t}, J=5.4 \mathrm{~Hz}, \mathrm{NH}), 4.35(\mathrm{q}, J=7.1 \mathrm{~Hz}, 2 \mathrm{H}), 3.89(\mathrm{dd}, J=12.4,6.6 \mathrm{~Hz}$, $2 \mathrm{H}), 3.23-3.12(\mathrm{~m}, 4 \mathrm{H}), 3.04(\mathrm{~m}, 2 \mathrm{H}), 2.76(\mathrm{~s}, 3 \mathrm{H}), 1.39(\mathrm{t}, J=7.1 \mathrm{~Hz}, 3 \mathrm{H}) .{ }^{13} \mathrm{C}$ NMR $(75$ $\left.\mathrm{MHz}, \mathrm{CDCl}_{3}\right) \delta 168.00,163.30,161.51(\mathrm{~d}, J=244.8 \mathrm{~Hz}), 158.99,142.10,138.29,131.46$ $(\mathrm{d}, J=4.9 \mathrm{~Hz}), 128.86,128.75,128.70,128.55,126.08(\mathrm{~d}, J=16.0 \mathrm{~Hz}), 126.06,124.60(\mathrm{~d}, J$ $=3.5 \mathrm{~Hz}), 121.55,115.75(\mathrm{~d}, J=22.0 \mathrm{~Hz}), 115.31,61.46,41.41,41.16,34.52,29.03,15.68$, 14.58. MS (ESI): calcd. 464.18; found $464.47[\mathrm{M}+\mathrm{H}]^{+}$.

\section{Ethyl 5-methyl-4-((4-methylphenethyl)amino)-2-phenethylthieno[2,3-d]pyrimidine-6- carboxylate $10(\mathrm{~d}, \mathrm{~m})$}

Isolated $103 \mathrm{mg}\left(77 \%\right.$ yield) as a white solid. ${ }^{1} \mathrm{H}$ NMR $\left(300 \mathrm{MHz}, \mathrm{CDCl}_{3}\right) \delta 7.34-7.10$ $(\mathrm{m}, 9 \mathrm{H}), 5.61(\mathrm{t}, J=5.3 \mathrm{~Hz}, \mathrm{NH}), 4.35(\mathrm{q}, J=7.1 \mathrm{~Hz}, 2 \mathrm{H}), 3.88(\mathrm{dd}, J=12.2,6.6 \mathrm{~Hz}, 2 \mathrm{H})$, $3.24-3.13(\mathrm{~m}, 4 \mathrm{H}), 2.95(\mathrm{t}, J=6.7 \mathrm{~Hz}, 2 \mathrm{H}), 2.69(\mathrm{~s}, 3 \mathrm{H}), 2.36(\mathrm{~s}, 3 \mathrm{H}), 1.40(\mathrm{t}, J=7.1 \mathrm{~Hz}$, $3 \mathrm{H}) .{ }^{13} \mathrm{C}$ NMR $\left(75 \mathrm{MHz}, \mathrm{CDCl}_{3}\right) \delta 168.09,163.33,159.00,142.11,138.36,136.59,135.89$, 129.76, 128.96, 128.71, 128.56, 126.07, 121.45, 115.34, 61.44, 42.41, 41.19, 34.93, 34.57, 21.32, 15.68, 14.59. MS (ESI): calcd. 460.21 ; found $460.47[\mathrm{M}+\mathrm{H}]^{+}$.

\section{Ethyl 5-methyl-4-((3-methylphenethyl)amino)-2-phenethylthieno[2,3-d]pyrimidine-6- carboxylate 10(d,n)}

Isolated $113 \mathrm{mg}$ ( $84 \%$ yield) as an off-white solid. ${ }^{1} \mathrm{H}$ NMR $\left(300 \mathrm{MHz}, \mathrm{CDCl}_{3}\right) \delta 7.34-$ $7.16(\mathrm{~m}, 6 \mathrm{H}), 7.07(\mathrm{~m}, 3 \mathrm{H}), 5.61(\mathrm{t}, J=5.3 \mathrm{~Hz}, \mathrm{NH}), 4.35(\mathrm{q}, J=7.1 \mathrm{~Hz}, 2 \mathrm{H}), 3.89$ (dd, $J=$ $12.2,6.6 \mathrm{~Hz}, 2 \mathrm{H}), 3.19(\mathrm{~m}, 4 \mathrm{H}), 2.95(\mathrm{t}, J=6.7 \mathrm{~Hz}, 2 \mathrm{H}), 2.69(\mathrm{~s}, 3 \mathrm{H}), 2.36(\mathrm{~s}, 3 \mathrm{H}), 1.39(\mathrm{t}, J$ $=7.1 \mathrm{~Hz}, 3 \mathrm{H}) .{ }^{13} \mathrm{C} \mathrm{NMR}\left(75 \mathrm{MHz}, \mathrm{CDCl}_{3}\right) \delta 168.09,163.31,159.00,142.11,138.97$, $138.74,138.33,129.89,129.03,128.71,128.56,127.79,126.09,126.07,121.46,115.36$, $61.45,42.36,41.20,35.29,34.58,21.66,15.61,14.58$. MS (ESI): calcd. 460.21; found $460.50[\mathrm{M}+\mathrm{H}]^{+}$. 


\section{Ethyl 5-methyl-4-((2-methylphenethyl)amino)-2-phenethylthieno[2,3-d]pyrimidine-6- carboxylate 10(d,o)}

Isolated $101 \mathrm{mg}(75 \%$ yield $)$ as a pale yellow solid. ${ }^{1} \mathrm{H} \mathrm{NMR}\left(300 \mathrm{MHz}, \mathrm{CDCl}_{3}\right) \delta 7.33-$ $7.14(\mathrm{~m}, 9 \mathrm{H}), 5.68(\mathrm{t}, J=5.5 \mathrm{~Hz}, \mathrm{NH}), 4.36(\mathrm{q}, J=7.1 \mathrm{~Hz}, 2 \mathrm{H}), 3.87(\mathrm{dd}, J=12.8,7.0 \mathrm{~Hz}$, $2 \mathrm{H}), 3.19(\mathrm{~m}, 4 \mathrm{H}), 3.01(\mathrm{t}, J=7.1 \mathrm{~Hz}, 2 \mathrm{H}), 2.76(\mathrm{~s}, 3 \mathrm{H}), 2.41(\mathrm{~s}, 3 \mathrm{H}), 1.40(\mathrm{t}, J=7.1 \mathrm{~Hz}$, $3 \mathrm{H}) .{ }^{13} \mathrm{C} \mathrm{NMR}\left(75 \mathrm{MHz}, \mathrm{CDCl}_{3}\right) \delta 168.10,163.32,159.09,142.07,138.29,137.10,136.71$, $130.94,129.79,128.70,128.57,127.16,126.48,126.09,121.56,115.35,61.47,41.30$, 41.13, 34.69, 32.99, 19.71, 15.79, 14.59. MS (ESI): calcd. 460.21; found $460.47[\mathrm{M}+\mathrm{H}]^{+}$.

\section{Ethyl 5-methyl-2-phenethyl-4-((2-(pyridin-4-yl)ethyl)amino)thieno[2,3-d]pyrimidine-6- carboxylate $10(d, p)$}

Isolated $70 \mathrm{mg}$ (72\% yield) as a pale yellow solid. ${ }^{1} \mathrm{H}$ NMR (500 MHz, DMSO) $\delta 8.45$ (d, $J$ $=5.9 \mathrm{~Hz}, 2 \mathrm{H}), 7.25(\mathrm{~d}, J=6.0 \mathrm{~Hz}, 2 \mathrm{H}), 7.22(\mathrm{~m}, 4 \mathrm{H}), 7.18(\mathrm{br} . \mathrm{t}, J=5.8 \mathrm{~Hz}, \mathrm{NH}), 7.13(\mathrm{~m}$, $1 \mathrm{H}), 4.28(\mathrm{q}, J=7.1 \mathrm{~Hz}, 2 \mathrm{H}), 3.77(\mathrm{dd}, J=13.5,6.5 \mathrm{~Hz}, 2 \mathrm{H}), 3.10-3.05(\mathrm{~m}, 2 \mathrm{H}), 3.03-$ $2.98(\mathrm{~m}, 2 \mathrm{H}), 2.92(\mathrm{dd}, J=10.3,4.0 \mathrm{~Hz}, 2 \mathrm{H}), 2.81(\mathrm{~s}, 3 \mathrm{H}), 1.29(\mathrm{t}, J=7.1 \mathrm{~Hz}, 3 \mathrm{H}) .{ }^{13} \mathrm{C}$ NMR (126 MHz, DMSO) $\delta 168.27,159.30,150.69,149.70,140.91,129.45,127.00,125.50$, $62.28,42.30,35.00,34.48,16.68,15.37$. MS (ESI): calcd. 447.185; found 447.20 [M+H] ${ }^{+}$.

\section{Ethyl 5-methyl-2-phenethyl-4-((2-(pyridin-3-yl)ethyl)amino)thieno[2,3-d]pyrimidine-6- carboxylate 10(d,q)}

Isolated $54 \mathrm{mg}$ (41\% yield) as a pale yellow solid. ${ }^{1} \mathrm{H}$ NMR (500 MHz, DMSO) $\delta 8.46$ (s, $1 \mathrm{H}), 8.41(\mathrm{~d}, J=4.5 \mathrm{~Hz}, 1 \mathrm{H}), 7.64(\mathrm{~d}, J=7.8 \mathrm{~Hz}, 1 \mathrm{H}), 7.31(\mathrm{dd}, J=7.7,4.8 \mathrm{~Hz}, 1 \mathrm{H}), 7.25-$ $7.21(\mathrm{~m}, 4 \mathrm{H}), 7.19-7.12(\mathrm{~m}, \mathrm{NH}, 1 \mathrm{H}), 4.28(\mathrm{q}, J=7.1 \mathrm{~Hz}, 2 \mathrm{H}), 3.76(\mathrm{dd}, J=13.1,6.7 \mathrm{~Hz}$, $2 \mathrm{H}), 3.10-3.05(\mathrm{~m}, 2 \mathrm{H}), 3.00(\mathrm{dd}, J=8.4,6.2 \mathrm{~Hz}, 2 \mathrm{H}), 2.93(\mathrm{t}, J=7.1 \mathrm{~Hz}, 2 \mathrm{H}), 2.81$ (s, $3 \mathrm{H}), 1.29$ (t, $J=7.1 \mathrm{~Hz}, 3 \mathrm{H}) .{ }^{13} \mathrm{C}$ NMR $(126 \mathrm{MHz}, \mathrm{DMSO}) \delta 168.19,163.47,159.26$, 151.00, 148.56, 142.66, 140.86, 137.49, 136.20, 129.41, 126.95, 124.63, 120.37, 115.78, 62.21, 42.92, 41.25, 34.48, 32.87, 16.65, 15.32. MS (ESI): calcd. 447.185; found 447.27 [M $+\mathrm{H}]^{+}$.

\section{Ethyl 5-methyl-2-phenethyl-4-((2-(pyridin-2-yl)ethyl)amino)thieno[2,3-d]pyrimidine-6- carboxylate 10(d,r)}

Isolated $118 \mathrm{mg}$ (90\% yield) as a pale yellow solid. ${ }^{1} \mathrm{H} \mathrm{NMR}\left(300 \mathrm{MHz}, \mathrm{CDCl}_{3}\right) \delta 8.52$ (dd, $J=5.8,1.7 \mathrm{~Hz}, 1 \mathrm{H}), 7.62(\mathrm{td}, J=7.7,1.8 \mathrm{~Hz}, 1 \mathrm{H}), 7.49(\mathrm{~s}, \mathrm{NH}), 7.31-7.23(\mathrm{~m}, 4 \mathrm{H}), 7.21-$ $7.13(\mathrm{~m}, 3 \mathrm{H}), 4.34(\mathrm{q}, J=7.1 \mathrm{~Hz}, 2 \mathrm{H}), 4.02(\mathrm{dd}, J=11.5,5.2 \mathrm{~Hz}, 2 \mathrm{H}), 3.19-3.06(\mathrm{~m}, 6 \mathrm{H})$, 2.97 (s, 3H), 1.38 (t, $J=7.1 \mathrm{~Hz}, 3 \mathrm{H}) .{ }^{13} \mathrm{C} \mathrm{NMR}\left(75 \mathrm{MHz}, \mathrm{CDCl}_{3}\right) \delta 168.08,168.01,163.46$, $160.33,158.80,149.13,142.21,139.20,137.12,128.71,128.51,126.00,123.76,122.02$, 120.96, 115.53, 61.35, 41.19, 40.27, 36.09, 34.56, 15.79, 14.60. MS (ESI): calcd. 447.19; found $447.40[\mathrm{M}+\mathrm{H}]^{+}$.

Ethyl 4-((2,3-dihydro-1H-inden-2-yl)amino)-5-methyl-2-phenethylthieno[2,3-d]pyrimidine-6carboxylate $10(d, x)$

Isolated $105 \mathrm{mg}(79 \%$ yield $)$ as a pale yellow solid. ${ }^{1} \mathrm{H} \mathrm{NMR}\left(300 \mathrm{MHz}, \mathrm{CDCl}_{3}\right) \delta 7.33-$ $7.17(\mathrm{~m}, 9 \mathrm{H}), 5.82(\mathrm{~d}, J=6.7 \mathrm{~Hz}, \mathrm{NH}), 5.13(\mathrm{~m}, 1 \mathrm{H}), 4.36(\mathrm{q}, J=7.1 \mathrm{~Hz}, 2 \mathrm{H}), 3.52(\mathrm{~d}, J=$ $7.3 \mathrm{~Hz}, 2 \mathrm{H}), 3.46(\mathrm{~d}, J=7.2 \mathrm{~Hz}, 2 \mathrm{H}), 2.95(\mathrm{~d}, J=5.4 \mathrm{~Hz}, 2 \mathrm{H}), 2.89$ (d, $J=5.5 \mathrm{~Hz}, 2 \mathrm{H}), 2.84$ 
(s, 3H), 1.40 (t, $J=7.1 \mathrm{~Hz}, 3 \mathrm{H}) .{ }^{13} \mathrm{C}$ NMR $\left(75 \mathrm{MHz}, \mathrm{CDCl}_{3}\right) \delta$ 168.03, 163.28, 158.79, $142.05,141.03,138.10,0128.71,128.57,127.14,126.08,125.10,121.73,115.31,61.49$, 52.48, 41.12, 40.45, 34.57, 15.88, 14.58. MS (ESI): calcd. 458.19; found $458.47[\mathrm{M}+\mathrm{H}]^{+}$.

Ethyl 4-((3,5-dimethoxyphenethyl)amino)-5-methyl-2-phenethylthieno[2,3-d]pyrimidine-6carboxylate $10(d, y)$

Isolated $77 \mathrm{mg}$ (52\% yield) as a pale yellow solid. ${ }^{1} \mathrm{H}$ NMR (500 MHz, DMSO) $\delta 7.23(\mathrm{~m}$, $4 \mathrm{H}), 7.16-7.09(\mathrm{~m}, 1 \mathrm{H}, \mathrm{NH}), 6.41(\mathrm{~s}, 2 \mathrm{H}), 6.33(\mathrm{~s}, 1 \mathrm{H}), 4.28(\mathrm{q}, J=7.1 \mathrm{~Hz}, 2 \mathrm{H}), 3.73(\mathrm{dd}, J$ $=13.7,6.3 \mathrm{~Hz}, 2 \mathrm{H}), 3.67(\mathrm{~s}, 6 \mathrm{H}), 3.10(\mathrm{~m}, 2 \mathrm{H}), 3.04-2.98(\mathrm{~m}, 2 \mathrm{H}), 2.88-2.79(\mathrm{~m}, 5 \mathrm{H})$, 1.29 (t, $J=7.1 \mathrm{~Hz}, 3 \mathrm{H}) .{ }^{13} \mathrm{C}$ NMR (126 MHz, DMSO) $\delta 168.21,168.18,163.44,161.61$, $159.23,142.96,142.67,140.85,129.39,129.37,126.94,120.26,115.78,107.80,99.12$, $62.15,56.10,43.39,41.34,36.05,34.48,16.60,15.29$. MS (ESI): calcd. 506.21; found $506.53[\mathrm{M}+\mathrm{H}]^{+}$

\section{Ethyl 4-((2-(benzo[d][1,3]dioxol-5-yl)ethyl)amino)-5-methyl-2-phenethylthieno[2,3- d]pyrimidine-6-carboxylate $10(d, z)$}

Isolated $94 \mathrm{mg}$ (66\% yield) as a pale yellow solid. ${ }^{1} \mathrm{H}$ NMR (500 MHz, DMSO) $\delta 7.27-$ $7.20(\mathrm{~m}, 4 \mathrm{H}), 7.10(\mathrm{~s}, 1 \mathrm{H}, \mathrm{NH}), 6.85-6.79(\mathrm{~m}, 2 \mathrm{H}), 6.68(\mathrm{~d}, J=7.9 \mathrm{~Hz}, 1 \mathrm{H}), 5.95(\mathrm{~s}, 2 \mathrm{H})$, $4.28(\mathrm{q}, J=7.1 \mathrm{~Hz}, 2 \mathrm{H}), 3.69$ (dd, $J=14.1,6.3 \mathrm{~Hz}, 2 \mathrm{H}), 3.12-3.05(\mathrm{~m}, 2 \mathrm{H}), 3.05-2.95$ $(\mathrm{m}, 2 \mathrm{H}), 2.85-2.78(\mathrm{~m}, 5 \mathrm{H}), 1.29$ (t, $J=7.1 \mathrm{~Hz}, 3 \mathrm{H}) .{ }^{13} \mathrm{C}$ NMR $(126 \mathrm{MHz}, \mathrm{DMSO}) \delta$ $168.19,163.45,159.23,148.42,146.70,142.67,140.87,134.41,129.40,129.38,126.94$, $122.67,120.25,115.76,110.12,109.30,101.84,62.15,43.63,41.32,35.45,34.49,16.62$, 15.31. MS (ESI): calcd. 490.18; found $490.47[\mathrm{M}+\mathrm{H}]^{+}$.

\section{Ethyl 5-methyl-4-(methylamino)-2-(3-phenylpropyl)thieno[2,3-d]pyrimidine-6-carboxylate 10(e,a) \\ Isolated $52 \mathrm{mg}$ ( $33 \%$ yield) as a yellow oil. ${ }^{1} \mathrm{H} \mathrm{NMR}\left(300 \mathrm{MHz}, \mathrm{CDCl}_{3}\right) \delta 7.26-7.14(\mathrm{~m}$, $5 \mathrm{H}), 5.67(\mathrm{~m}, \mathrm{NH}), 4.33(\mathrm{q}, J=7.1 \mathrm{~Hz}, 2 \mathrm{H}), 3.12(\mathrm{~d}, J=4.8 \mathrm{~Hz}, 3 \mathrm{H}), 2.88(\mathrm{~s}, 3 \mathrm{H}), 2.84(\mathrm{~m}$, $2 \mathrm{H}), 2.75-2.67(\mathrm{~m}, 2 \mathrm{H}), 2.22-2.11(\mathrm{~m}, 2 \mathrm{H}), 1.37(\mathrm{t}, J=7.1 \mathrm{~Hz}, 3 \mathrm{H}) .{ }^{13} \mathrm{C}$ NMR $(75 \mathrm{MHz}$, $\left.\mathrm{CDCl}_{3}\right) \delta 168.72,167.83,163.32,159.61,142.63,138.32,128.75,128.45,125.88,121.25$, 115.33, 61.42, 39.21, 35.91, 30.26, 28.33, 15.93, 14.56. MS (ESI): calcd. 370.159; found $370.33[\mathrm{M}+\mathrm{H}]^{+}$}

\section{Ethyl 5-methyl-4-(methylamino)-2-(4-phenylbutyl)thieno[2,3-d]pyrimidine-6-carboxylate 10(f,a)}

Isolated $88 \mathrm{mg}\left(43 \%\right.$ yield) as a pale yellow syrup. ${ }^{1} \mathrm{H} \mathrm{NMR}\left(300 \mathrm{MHz}, \mathrm{CDCl}_{3}\right) \delta 7.29-$ 7.13 (m, 5H), 5.64 (br. m, NH), 4.34 (q, $J=7.1 \mathrm{~Hz}, 2 \mathrm{H}), 3.11$ (d, $J=4.8 \mathrm{~Hz}, 3 \mathrm{H}), 2.89$ (s, $3 \mathrm{H}), 2.88-2.81(\mathrm{~m}, 2 \mathrm{H}), 2.70-2.63(\mathrm{~m}, 2 \mathrm{H}), 1.95-1.83(\mathrm{~m}, 2 \mathrm{H}), 1.78-1.67(\mathrm{~m}, 2 \mathrm{H})$, $1.38(\mathrm{t}, J=7.1 \mathrm{~Hz}, 3 \mathrm{H}) .{ }^{13} \mathrm{C}$ NMR $\left(75 \mathrm{MHz}, \mathrm{CDCl}_{3}\right) \delta 168.96,167.88,163.35,159.64$, $142.89,138.27,128.65,128.43,125.80,121.27,115.32,61.42,39.51,36.06,31.51,28.30$, 15.95, 14.57. MS (ESI): calcd. 384.175; found $384.27[\mathrm{M}+\mathrm{H}]^{+}$. 


\section{Ethyl 2-(3-methoxyphenethyl)-5-methyl-4-(methylamino)thieno[2,3-d]pyrimidine-6- carboxylate 10(h,a)}

Isolated $163 \mathrm{mg}$ (83\% yield) as a pale yellow solid. ${ }^{1} \mathrm{H}$ NMR $\left(300 \mathrm{MHz}, \mathrm{CDCl}_{3}\right) \delta 7.16(\mathrm{t}, J$ $=7.8 \mathrm{~Hz}, 1 \mathrm{H}), 6.84(\mathrm{~m}, 2 \mathrm{H}), 6.70(\mathrm{dd}, J=8.1,2.5 \mathrm{~Hz}, 1 \mathrm{H}), 5.66$ (br. m, NH), $4.33(\mathrm{q}, J=7.1$ $\mathrm{Hz}, 2 \mathrm{H}), 3.75$ (s, 3H), $3.15-3.08(\mathrm{~m}, 7 \mathrm{H}), 2.86(\mathrm{~s}, 3 \mathrm{H}), 1.37(\mathrm{t}, J=7.1 \mathrm{~Hz}, 3 \mathrm{H}) .{ }^{13} \mathrm{C}$ NMR $\left(75 \mathrm{MHz}, \mathrm{CDCl}_{3}\right) \delta 167.96,163.29,159.77,159.61,143.75,138.29,129.46,121.37$, $121.09,115.41,114.25,111.53,61.44,55.32,41.06,34.48,28.32,15.90,14.56$. MS (ESI): calcd. 386.154; found $386.27[\mathrm{M}+\mathrm{H}]^{+}$.

\section{Ethyl 2-(3-fluorophenethyl)-5-methyl-4-(methylamino)thieno[2,3-d]pyrimidine-6-carboxylate 10(k,a) \\ Isolated $141 \mathrm{mg}\left(54 \%\right.$ yield) as a pale yellow oil. ${ }^{1} \mathrm{H} \mathrm{NMR}\left(300 \mathrm{MHz}, \mathrm{CDCl}_{3}\right) \delta 7.21-7.13$ $(\mathrm{m}, 1 \mathrm{H}), 7.05-6.92(\mathrm{~m}, 2 \mathrm{H}), 6.84(\mathrm{td}, J=8.5,2.6 \mathrm{~Hz}, 1 \mathrm{H}), 5.66$ (br. m, NH), 4.33 (q, $J=$ $7.1 \mathrm{~Hz}, 2 \mathrm{H}), 3.17-3.06(\mathrm{~m}, 7 \mathrm{H}), 2.88(\mathrm{~s}, 3 \mathrm{H}), 1.37(\mathrm{t}, J=7.1 \mathrm{~Hz}, 3 \mathrm{H}) .{ }^{13} \mathrm{C} \mathrm{NMR}(75 \mathrm{MHz}$, $\left.\mathrm{CDCl}_{3}\right) \delta 167.80,167.58,164.66,163.28,161.41,159.61,144.70(\mathrm{~d}, J=7.2 \mathrm{~Hz}), 138.21$, 129.85 (d, $J=8.4 \mathrm{~Hz}), 124.34$ (d, $J=2.6 \mathrm{~Hz}), 121.51,115.42$ (d, $J=3.6 \mathrm{~Hz}), 112.84$ (d, $J=$ $21.0 \mathrm{~Hz}$ ), 61.46, 40.67, 34.02, 28.32, 15.92, 14.54. MS (ESI): calcd. 374.134; found 374.20 $[\mathrm{M}+\mathrm{H}]^{+}$.}

\section{Ethyl 5-methyl-4-(methylamino)-2-(2-(pyridin-2-yl)ethyl)thieno[2,3-d]pyrimidine-6- carboxylate 10(q,a)}

Isolated $585 \mathrm{mg}$ (57\% yield) as a white solid. ${ }^{1} \mathrm{H}$ NMR $\left(300 \mathrm{MHz}, \mathrm{CDCl}_{3}\right) \delta 8.54$ (ddd, $J=$ $5.0,1.7,0.8 \mathrm{~Hz}, 1 \mathrm{H}), 7.65(\mathrm{td}, J=7.7,1.8 \mathrm{~Hz}, 1 \mathrm{H}), 7.29(\mathrm{~d}, J=7.9 \mathrm{~Hz}, 1 \mathrm{H}), 7.17$ (ddd, $J=$ 7.5, 5.0, $1.1 \mathrm{~Hz}, 1 \mathrm{H}), 5.68$ (br. m, NH), 4.34 (q, $J=7.1 \mathrm{~Hz}, 2 \mathrm{H}), 3.45-3.35$ (m, 2H), 3.29 $(\mathrm{m}, 2 \mathrm{H}), 3.08(\mathrm{~d}, J=4.7 \mathrm{~Hz}, 3 \mathrm{H}), 2.91(\mathrm{~s}, 3 \mathrm{H}), 1.38(\mathrm{t}, J=7.1 \mathrm{~Hz}, 3 \mathrm{H}) .{ }^{13} \mathrm{C} \mathrm{NMR}(75 \mathrm{MHz}$, $\left.\mathrm{CDCl}_{3}\right) \delta 167.41,163.29,161.18,159.61,148.18,138.21,137.73,123.64,121.71,121.59$, $115.48,61.47,38.68,35.79,28.39,15.96,14.55$. MS (ESI): calcd. 357.139; found 357.20 $[\mathrm{M}+\mathrm{H}]^{+}$.

\section{Ethyl 2-(4-acetamidophenethyl)-5-methyl-4-(methylamino)thieno[2,3-d]pyrimidine-6- carboxylate 10(s,a)}

Isolated $38 \mathrm{mg}$ (68\% yield) as a beige solid. ${ }^{1} \mathrm{H}$ NMR (500 MHz, DMSO) $\delta 9.83$ (s, NHAc), $7.41(\mathrm{~d}, J=8.4 \mathrm{~Hz}, 2 \mathrm{H}), 7.13(\mathrm{~d}, J=8.2 \mathrm{~Hz}, 2 \mathrm{H}), 7.09(\mathrm{~m}, \mathrm{NH}), 4.27(\mathrm{q}, J=7.1 \mathrm{~Hz}, 2 \mathrm{H})$, $3.02-2.94(\mathrm{~m}, 7 \mathrm{H}), 2.86(\mathrm{~s}, 3 \mathrm{H}), 1.98(\mathrm{~s}, 3 \mathrm{H}), 1.28(\mathrm{t}, J=7.1 \mathrm{~Hz}, 3 \mathrm{H}) .{ }^{13} \mathrm{C}$ NMR $(126$ $\left.\mathrm{MHz}, \mathrm{CDCl}_{3}+\mathrm{CD}_{3} \mathrm{OD}\right) \delta 174.50,172.26,171.43,167.85,164.01,143.40,142.04,140.74$, 133.30, 125.53, 124.67, 119.90, 65.95, 45.18, 38.26, 32.49, 28.11, 19.95, 18.70. MS (ESI): calcd. 413.16; found $413.33[\mathrm{M}+\mathrm{H}]^{+}$.

\section{Ethyl 2-(4-acetamidophenethyl)-4-((2-aminoethyl)amino)-5-methylthieno[2,3-d]pyrimidine-6- carboxylate $10(s, b)$}

Isolated $51 \mathrm{mg}\left(83 \%\right.$ yield) as a white solid. ${ }^{1} \mathrm{H}$ NMR (300 MHz, DMSO) $\delta 9.81$ (s, NHAc), 7.43 (d, $J=8.4 \mathrm{~Hz}, 2 \mathrm{H}), 7.14$ (d, $J=8.4 \mathrm{~Hz}, 2 \mathrm{H}), 7.07-6.96$ (m, NH), 4.26 (q, $J=$ $7.0 \mathrm{~Hz}, 2 \mathrm{H}), 3.57$ (dd, $J=11.0,5.5 \mathrm{~Hz}, 2 \mathrm{H}), 3.23(\mathrm{dd}, J=11.6,6.1 \mathrm{~Hz}, 2 \mathrm{H}), 3.03-2.90(\mathrm{~m}$, $4 \mathrm{H}), 2.86$ (s, 3H), 1.99 (s, 3H), 1.27 (t, $J=7.1 \mathrm{~Hz}, 3 \mathrm{H}) .{ }^{13} \mathrm{C}$ NMR (75 MHz, DMSO) $\delta$ 
$167.69,162.98,159.06,156.71,140.62,137.83,136.80,129.09,119.63,115.35,78.38$, 61.67, 33.38, 24.59, 21.41, 16.11, 14.81. MS (ESI): calcd. 442.191; found 442.27 [M+H] ${ }^{+}$.

\section{Ethyl 2-(4-acetamidophenethyl)-5-methyl-4-((2-(pyridin-4-yl)ethyl)amino)thieno[2,3- d]pyrimidine-6-carboxylate $10(s, p)$}

Isolated $86 \mathrm{mg}$ (68\% yield) as a pale yellow solid. ${ }^{1} \mathrm{H}$ NMR (500 MHz, DMSO) $\delta 9.83(\mathrm{~s}$, NHAc), $8.46(\mathrm{~d}, J=4.7 \mathrm{~Hz}, 2 \mathrm{H}), 7.45(\mathrm{~d}, J=8.2 \mathrm{~Hz}, 2 \mathrm{H}), 7.24(\mathrm{~m}, 2 \mathrm{H}, \mathrm{NH}), 7.12(\mathrm{~d}, J=8.2$ $\mathrm{Hz}, 2 \mathrm{H}), 4.26$ (q, $J=7.0 \mathrm{~Hz}, 2 \mathrm{H}), 3.76(\mathrm{dd}, J=12.7,6.4 \mathrm{~Hz}, 2 \mathrm{H}), 3.07-2.90(\mathrm{~m}, 6 \mathrm{H}), 2.79$ (s, 3H), 2.00 (s, 3H), 1.28 (t, $J=7.0 \mathrm{~Hz}, 3 \mathrm{H}) .{ }^{13} \mathrm{C}$ NMR (126 MHz, DMSO) $\delta 169.24$, $168.18,163.44,159.18,150.63,149.67,140.79,138.35,137.19,129.51,129.43,129.38$,

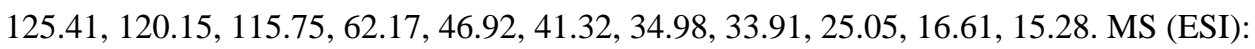
calcd. 504.207; found $504.13[\mathrm{M}+\mathrm{H}]^{+}$.

\section{Ethyl 2-(4-acetamidophenethyl)-5-methyl-4-((2-(pyridin-3-yl)ethyl)amino)thieno[2,3- d]pyrimidine-6-carboxylate 10(s,q)}

Isolated $79 \mathrm{mg}$ (63\% yield) as a pale yellow solid. ${ }^{1} \mathrm{H}$ NMR (500 MHz, DMSO) $\delta 9.83$ (s, NHAc), $8.41(\mathrm{~d}, J=4.7 \mathrm{~Hz}, 1 \mathrm{H}), 7.63(\mathrm{~d}, J=7.7 \mathrm{~Hz}, 1 \mathrm{H}), 7.46(\mathrm{~m}, J=15.7,8.4 \mathrm{~Hz}, 3 \mathrm{H})$, $7.30(\mathrm{dd}, J=7.7,4.8 \mathrm{~Hz}, 1 \mathrm{H}), 7.18-7.10(\mathrm{~m}, 2 \mathrm{H}, \mathrm{NH}), 4.27(\mathrm{q}, J=7.0 \mathrm{~Hz}, 2 \mathrm{H}), 3.76$ (dd, $J$ $=12.9,6.6 \mathrm{~Hz}, 2 \mathrm{H}), 3.06-2.91(\mathrm{~m}, 6 \mathrm{H}), 2.80(\mathrm{~s}, 3 \mathrm{H}), 2.00(\mathrm{~s}, 3 \mathrm{H}), 1.29(\mathrm{t}, J=7.1 \mathrm{~Hz}$, $3 \mathrm{H}) .{ }^{13} \mathrm{C}$ NMR (126 MHz, DMSO) $\delta 168.20,163.45,159.23,151.01,148.58,140.83$, $137.41,137.19,136.19,129.62,129.52,124.60,120.22,120.13,115.75,62.18,47.02$, 33.93, 32.88, 27.10, 25.06, 16.63, 15.30. MS (ESI): calcd. 504.207; found $504.27[\mathrm{M}+\mathrm{H}]^{+}$.

\section{Ethyl 2-(4-acetamidophenethyl)-5-methyl-4-((2-(pyridin-2-yl)ethyl)amino)thieno[2,3- d]pyrimidine-6-carboxylate 10(s,r)}

Isolated $55 \mathrm{mg}$ (44\% yield) as a pale yellow solid. ${ }^{1} \mathrm{H}$ NMR (500 MHz, DMSO) $\delta 9.83(\mathrm{~s}$, NHAc), $8.52(\mathrm{~d}, J=4.1 \mathrm{~Hz}, 1 \mathrm{H}), 7.71(\mathrm{t}, J=7.6 \mathrm{~Hz}, 1 \mathrm{H}), 7.43(\mathrm{~m}, 2 \mathrm{H}, \mathrm{NH}), 7.28(\mathrm{~d}, J=7.4$ $\mathrm{Hz}, 1 \mathrm{H}), 7.24(\mathrm{dd}, J=7.4,4.9 \mathrm{~Hz}, 1 \mathrm{H}), 7.14(\mathrm{~d}, J=8.3 \mathrm{~Hz}, 2 \mathrm{H}), 4.27$ (q, $J=7.1 \mathrm{~Hz}, 2 \mathrm{H})$, $3.88(\mathrm{dd}, J=12.3,6.4 \mathrm{~Hz}, 2 \mathrm{H}), 3.09(\mathrm{~m}, 2 \mathrm{H}), 3.05-2.99(\mathrm{~m}, 2 \mathrm{H}), 2.96(\mathrm{dd}, J=8.2,6.3 \mathrm{~Hz}$, $2 \mathrm{H}), 2.84$ (s, 3H), 2.00 (s, 3H), 1.29 (t, $J=7.1 \mathrm{~Hz}, 3 \mathrm{H}) .{ }^{13} \mathrm{C}$ NMR (126 MHz, DMSO) $\delta$ 169.20, 168.29, 168.13, 163.46, 160.72, 159.20, 150.13, 140.80, 138.33, 137.87, 137.24, $129.56,124.47,122.79,120.33,120.14,115.79,62.17,41.60,41.33,37.36,33.85,25.09$, 16.52, 15.31. MS (ESI): calcd. 504.207; found 504.20 [M+H] $]^{+}$.

\section{Ethyl 2-(3-acetamidophenethyl)-5-methyl-4-(methylamino)thieno[2,3-d]pyrimidine-6- carboxylate 10(t,a)}

Isolated $45 \mathrm{mg}$ (81\% yield) as a white powder. ${ }^{1} \mathrm{H}$ NMR (500 MHz, DMSO) $\delta 9.84(\mathrm{~s}$, NHAc), $7.47(\mathrm{~s}, 1 \mathrm{H}), 7.36(\mathrm{~d}, J=7.7 \mathrm{~Hz}, 1 \mathrm{H}), 7.14(\mathrm{t}, J=7.8 \mathrm{~Hz}, 1 \mathrm{H}), 7.11(\mathrm{~m}, J=4.5 \mathrm{~Hz}$, $\mathrm{NH}), 6.90(\mathrm{~d}, J=7.6 \mathrm{~Hz}, 1 \mathrm{H}), 4.28(\mathrm{q}, J=7.1 \mathrm{~Hz}, 2 \mathrm{H}), 3.04-2.94(\mathrm{~m}, 7 \mathrm{H}), 2.87(\mathrm{~s}, 3 \mathrm{H})$, 2.00 (s, 3H), 1.28 (t, $J=7.1 \mathrm{~Hz}, 3 \mathrm{H}) .{ }^{13} \mathrm{C} \mathrm{NMR}\left(126 \mathrm{MHz}, \mathrm{CDCl}_{3}+\mathrm{CD}_{3} \mathrm{OD}\right) \delta 174.50$, 172.26, 171.43, 167.85, 164.01, 143.40, 142.04, 140.74, 133.30, 125.53, 124.67, 119.90, 65.95, 45.18, 38.26, 32.49, 28.11, 19.95, 18.70. MS (ESI): calcd. 413.16; found 413.30 [M $+\mathrm{H}]^{+}$. 


\section{Ethyl 2-(2-acetamidophenethyl)-5-methyl-4-(methylamino)thieno[2,3-d]pyrimidine-6- carboxylate 10(u,a)}

Isolated $35 \mathrm{mg}$ (63\% yield) as a white powder. ${ }^{1} \mathrm{H}$ NMR (500 MHz, DMSO) $\delta 9.43$ (s, NHAc), 7.29 (d, $J=7.8 \mathrm{~Hz}, 1 \mathrm{H}), 7.24(\mathrm{~d}, J=7.6 \mathrm{~Hz}, 1 \mathrm{H}), 7.13(\mathrm{t}, J=7.5 \mathrm{~Hz}, 1 \mathrm{H}), 7.08$ (m, $\mathrm{NH}, 1 \mathrm{H}), 4.27(\mathrm{q}, J=7.1 \mathrm{~Hz}, 2 \mathrm{H}), 3.03(\mathrm{~m}, 2 \mathrm{H}), 2.97(\mathrm{~d}, J=4.5 \mathrm{~Hz}, 3 \mathrm{H}), 2.93(\mathrm{~m}, 2 \mathrm{H}), 2.86$ (s, 3H), 2.03 (s, 3H), 1.27 (t, $J=7.1 \mathrm{~Hz}, 3 \mathrm{H}) .{ }^{13} \mathrm{C} \mathrm{NMR}\left(126 \mathrm{MHz}, \mathrm{CDCl}_{3}+\mathrm{CD}_{3} \mathrm{OD}\right) \delta$ $175.11,172.05,171.24,167.71,164.02,143.67,139.66,139.37,134.36,131.18,130.57$, $130.32,125.54,120.05,66.02,44.45,33.67,32.49,28.01,19.89,18.71$. MS (ESI): calcd. 413.16; found $413.10[\mathrm{M}+\mathrm{H}]^{+}$.

\section{Ethyl 2-(3-chlorophenethyl)-5-methyl-4-(methylamino)thieno[2,3-d]pyrimidine-6-carboxylate $10(v, a)$}

Isolated $122 \mathrm{mg}\left(47 \%\right.$ yield) as a pale yellow oil. ${ }^{1} \mathrm{H} \mathrm{NMR}\left(300 \mathrm{MHz}, \mathrm{CDCl}_{3}\right) \delta 7.26(\mathrm{~m}$, 1H), $7.15-7.08$ (m, 3H), 5.65 (br. m, NH), 4.32 (q, $J=7.1 \mathrm{~Hz}, 2 \mathrm{H}), 3.13-3.08(\mathrm{~m}, 7 \mathrm{H})$, $2.87(\mathrm{~s}, 3 \mathrm{H}), 1.36(\mathrm{t}, J=7.1 \mathrm{~Hz}, 3 \mathrm{H}) .{ }^{13} \mathrm{C} \mathrm{NMR}\left(75 \mathrm{MHz}, \mathrm{CDCl}_{3}\right) \delta 167.77,167.51,163.26$, $159.59,144.15,138.23,134.13,129.73,128.89,126.89,126.17,121.49,115.43,61.46$, 40.65, 33.94, 28.33, 15.91, 14.55. MS (ESI): calcd. 390.104; found $390.20[\mathrm{M}+\mathrm{H}]^{+}$.

\section{Ethyl 5-methyl-4-(methylamino)-2-(3-(trifluoromethyl)phenethyl)thieno[2,3-d]pyrimidine-6- carboxylate $10(w, a)$}

Isolated $128 \mathrm{mg}$ (50\% yield) as a pale yellow semi-solid. ${ }^{1} \mathrm{H}$ NMR $\left(300 \mathrm{MHz}, \mathrm{CDCl}_{3}\right) \delta$ 7.52 (s, 1H), 7.37 (m, 3H), 5.66 (br. m, NH), 4.32 (q, $J=7.1 \mathrm{~Hz}, 2 \mathrm{H}), 3.25-3.11$ (m, 4H), $3.09(\mathrm{~d}, J=4.8 \mathrm{~Hz}, 3 \mathrm{H}), 2.87(\mathrm{~s}, 3 \mathrm{H}), 1.36(\mathrm{t}, J=7.1 \mathrm{~Hz}, 3 \mathrm{H}) .{ }^{13} \mathrm{C} \mathrm{NMR}\left(75 \mathrm{MHz}, \mathrm{CDCl}_{3}\right)$ $\delta 167.77,167.36,163.25,159.60,142.95,138.20,132.09,130.62$ (d, $J=31.9 \mathrm{~Hz}), 128.88$, $125.52(\mathrm{~d}, J=3.8 \mathrm{~Hz}), 122.87(\mathrm{~d}, J=3.8 \mathrm{~Hz}), 121.55,115.43,61.46,40.61,34.04,28.26$, 15.88, 14.51. MS (ESI): calcd. 424.131; found $424.27[\mathrm{M}+\mathrm{H}]^{+}$.

\section{Ethyl 2-(2-(benzo[d][1,3]dioxol-5-yl)ethyl)-5-methyl-4-(methylamino)thieno[2,3- d]pyrimidine-6-carboxylate 10(z,a)}

Isolated $62 \mathrm{mg}$ (41\% yield) as a pale yellow solid. ${ }^{1} \mathrm{H}$ NMR (500 MHz, DMSO) $\delta 7.08(\mathrm{~m}$, $\mathrm{NH}), 6.81(\mathrm{~s}, 1 \mathrm{H}), 6.76(\mathrm{dd}, J=7.9,2.0 \mathrm{~Hz}, 1 \mathrm{H}), 6.67$ (d, $J=7.9 \mathrm{~Hz}, 1 \mathrm{H}), 5.92(\mathrm{~s}, 2 \mathrm{H}), 4.27$ (q, $J=7.1 \mathrm{~Hz}, 2 \mathrm{H}), 3.33(\mathrm{~s}, 3 \mathrm{H}), 3.02-2.93(\mathrm{~m}, 7 \mathrm{H}), 2.86(\mathrm{~s}, 3 \mathrm{H}), 1.28(\mathrm{t}, J=7.1 \mathrm{~Hz}$, $3 \mathrm{H}) .{ }^{13} \mathrm{C}$ NMR (126 MHz, DMSO) $\delta 168.23,167.95,163.50,159.82,148.24,146.36$, 141.08, 136.55, 122.20, 120.06, 115.93, 109.95, 109.16, 101.71, 62.16, 41.56, 34.09, 29.27, 16.73, 15.33. MS (ESI): calcd. 400.13; found $400.40[\mathrm{M}+\mathrm{H}]^{+}$.

\section{Dimethyl thiophene-2,5-dicarboxylate (13)}

An ice-cooled pressure vessel was charged with thiophene-2,5-carboxylic acid (2.5 g, 14.5 $\mathrm{mmol})$ and $50 \mathrm{~mL}$ anhydrous $\mathrm{MeOH}$; thionyl chloride $(4.2 \mathrm{~mL}, 58 \mathrm{mmol})$ was added dropwise via syringe and once gas evolution had ceased the vessel was tightly sealed with a Teflon screw cap. The reaction was stirred $1 \mathrm{~h}$ at $\mathrm{RT}$ and $3 \mathrm{~h}$ at $60^{\circ} \mathrm{C}$. The reaction mixture was cooled to RT and stirred open to air for $1 \mathrm{~h}$. The crude reaction mixture was diluted with $100 \mathrm{~mL}$ DCM, stirred for $1 \mathrm{~h}$ and decanted. The residue was collected by filtration and washed with DCM to obtain the desired product as a whit powder, $2.9 \mathrm{~g}$ (99\% yield). ${ }^{1} \mathrm{H}$ 
NMR (300 MHz, DMSO) $\delta 7.81$ (s, 2H), 3.85 (s, 6H). ${ }^{13} \mathrm{C}$ NMR (126 MHz, DMSO) $\delta$ $162.40,139.25,134.94,53.99$.

\section{Dimethyl 3-aminothiophene-2,5-dicarboxylate (14)}

An ice-cooled round-bottom flask was charged with $12(1.0 \mathrm{~g}, 5.0 \mathrm{mmol})$, followed by $5 \mathrm{~mL}$ sulfuric acid. Nitric acid $(0.50 \mathrm{~mL}, 6.2 \mathrm{mmol})$ was added slowly dropwise via syringe and the reaction was stirred at RT for $1 \mathrm{~h}$. The crude reaction mixture was carefully poured on ice-water and stirred for $1 \mathrm{~h}$. The suspension was filtered, washed with water and dried on high vacuum to furnish dimethyl 3-nitrothiophene-2,5-dicarboxylate as a white solid, $1.1 \mathrm{~g}$ (93\% yield). ${ }^{1} \mathrm{H}$ NMR (500 MHz, DMSO) $\delta 8.22$ (s, 1H), 3.88 (s, 6H). ${ }^{13} \mathrm{C}$ NMR (126 MHz, DMSO) $\delta 161.14,159.81,148.22,136.58,133.46,129.26,55.05,54.53$. A roundbottom flask was charged with dimethyl 3-nitrothiophene-2,5-dicarboxylate (1.0 g, 4.1 mmol), suspended in MeOH/THF 2:1 and purged with nitrogen. Pearlman's catalyst was added (286 mg, $2.0 \mathrm{mmol}, 20 \% \mathrm{Pd}(\mathrm{OH})_{2} / \mathrm{C}$, CAS 12135-22-7), and the reaction mixture was purged with $\mathrm{H}_{2}$ gas and equipped with an $\mathrm{H}_{2}$-filled balloon. The reaction was stirred at RT until complete consumption of starting material, as determined by TLC. The reaction mixture was purged with nitrogen and filtered through a plug of Celite, rinsing with EtOAc. The filtrate was concentrated in vacuo and the obtained material was used as such without further purification. Isolated $900 \mathrm{mg}\left(100 \%\right.$ yield) as a yellow powder. ${ }^{1} \mathrm{H} \mathrm{NMR}(500 \mathrm{MHz}$, DMSO) $\delta 7.22(\mathrm{~s}, 1 \mathrm{H}), 6.62\left(\mathrm{~s}, \mathrm{NH}_{2}\right), 3.80(\mathrm{~s}, 3 \mathrm{H}), 3.74(\mathrm{~s}, 3 \mathrm{H}) .{ }^{13} \mathrm{C} \mathrm{NMR}(126 \mathrm{MHz}$, DMSO) $\delta 164.82,162.69,155.01,136.68,126.34,103.33,53.84,52.61$.

Thienopyrimidinone formation, amine coupling and ester saponification performed as described in the general procedures.

\section{Methyl 4-(methylamino)-2-phenethylthieno[3,2-d]pyrimidine-6-carboxylate 16(d,a)}

Isolated $106 \mathrm{mg}$ (51\% yield) as a white solid. ${ }^{1} \mathrm{H}$ NMR (500 MHz, DMSO) $\delta 7.98(\mathrm{~m}, \mathrm{NH})$, $7.84(\mathrm{~s}, 1 \mathrm{H}), 7.22(\mathrm{~m}, 4 \mathrm{H}), 7.12(\mathrm{~m}, 1 \mathrm{H}), 3.87(\mathrm{~s}, 3 \mathrm{H}), 3.13-3.04(\mathrm{~m}, 4 \mathrm{H}), 2.98(\mathrm{~d}, J=4.5$ $\mathrm{Hz}, 3 \mathrm{H}) .{ }^{13} \mathrm{C}$ NMR $(126 \mathrm{MHz}$, DMSO) $\delta 167.61,163.19,159.25,158.42,142.92,137.95$, $130.96,129.43,129.35,126.84,117.58,54.06,34.81,26.99,26.93$. MS (ESI): calcd. 328.11; found $328.27[\mathrm{M}+\mathrm{H}]^{+}$.

\section{Methyl 2-(3-methoxyphenethyl)-4-(methylamino)thieno[3,2-d]pyrimidine-6-carboxylate 16(h,a)}

Isolated $100 \mathrm{mg}$ (64\% yield) as a pale yellow oil. MS (ESI): calcd. 358.123; found 358.27 $[\mathrm{M}+\mathrm{H}]^{+}$

\section{General procedure for the saponification of esters}

To solution of ester ( 1 equivalent) in 2:1 THF/MeOH was added $1 \mathrm{M} \mathrm{NaOH}$ (3 equivalents) and water to bring the final solvent ratio to $2: 1: 1 \mathrm{THF} / \mathrm{MeOH} / \mathrm{H}_{2} \mathrm{O}$. In cases where the starting material was not fully dissolved, the solution was heated to $50{ }^{\circ} \mathrm{C}$ as necessary. The reaction was stirred at RT until complete consumption of starting material as determined by TLC. The reaction mixture was acidified to $\mathrm{pH} 3$ with $1 \mathrm{M} \mathrm{HCl}$ and concentrated in vacuo. The resultant slurry was diluted with $5 \mathrm{~mL}$ water, filtered and washed successively with 
deionized water, and purification grade pentane. The obtained residue was dried on high vacuum to furnish the desired free carboxylic acids.

\section{5-Methyl-4-(methylamino)-2-phenethylthieno[2,3-d]pyrimidine-6-carboxylic acid (17)}

Isolated $32 \mathrm{mg}$ (87\% yield) as a white powder. ${ }^{1} \mathrm{H}$ NMR (500 MHz, DMSO) $\delta 7.27-7.23$ (m, 4H), $7.16(\mathrm{~m}, 1 \mathrm{H}), 7.07$ (br. d, $J=4.4 \mathrm{~Hz}, \mathrm{NH}), 3.10-3.06$ (m, 2H), $3.02-2.98$ (m, $5 \mathrm{H}), 2.87$ (s, 3H). ${ }^{13} \mathrm{C}$ NMR (126 MHz, DMSO) $\delta$ 166.82, 166.58, 164.06, 158.71, 141.62, 138.94, 128.33, 128.26, 125.79, 120.64, 115.00, 40.18, 33.32, 28.11, 15.44. HRMS (ESI): calcd. 328.11197 for $\mathrm{C}_{17} \mathrm{H}_{18} \mathrm{~N}_{3} \mathrm{O}_{2} \mathrm{~S}$; found $328.1112[\mathrm{M}+\mathrm{H}]^{+}$.

4-((2-Aminoethyl)amino)-5-methyl-2-phenethylthieno[2,3-d]pyrimidine-6-carboxylic acid (18)

Isolated $15 \mathrm{mg}$ (35\% yield) as a white powder. ${ }^{1} \mathrm{H}$ NMR (500 MHz, DMSO) $\delta 7.28-7.14$ (m, 4H), 7.04 (br. s, NH), $3.51(\mathrm{~m}, 2 \mathrm{H}), 3.28(\mathrm{~m}, 2 \mathrm{H}), 3.12-3.03(\mathrm{~m}, 2 \mathrm{H}), 3.06-2.93(\mathrm{~m}$, $5 \mathrm{H}), 2.58(\mathrm{~s}, 3 \mathrm{H}) .{ }^{13} \mathrm{C}$ NMR (126 MHz, DMSO) $\delta 166.91,166.32,163.82,158.03,142.57$, 139.42, 128.65, 128.97, 126.02, 120.41, 114.63, 47.69, 41.31, 33.89, 25.16, 16.46. HRMS (ESI): calcd. 357.13852 for $\mathrm{C}_{18} \mathrm{H}_{21} \mathrm{~N}_{4} \mathrm{O}_{2} \mathrm{~S}$; found $357.1389[\mathrm{M}+\mathrm{H}]^{+}$.

\section{4-(Benzylamino)-5-methyl-2-phenethylthieno[2,3-d]pyrimidine-6-carboxylic acid (19)}

Isolated $40 \mathrm{mg}$ (86\% yield) as a white crystalline material. ${ }^{1} \mathrm{H}$ NMR (500 MHz, DMSO) $\delta$ 7.96 (br. s, NH), 7.41 (d, $J=7.1 \mathrm{~Hz}, 2 \mathrm{H}), 7.32$ (t, $J=7.6 \mathrm{~Hz}, 2 \mathrm{H}), 7.25-7.21(\mathrm{~m}, 1 \mathrm{H}), 7.19$ (d, $J=7.5 \mathrm{~Hz}, 2 \mathrm{H}), 7.15-7.08(\mathrm{~m}, 3 \mathrm{H}), 4.79$ (d, $J=5.8 \mathrm{~Hz}, 2 \mathrm{H}), 2.96(\mathrm{~m}, 4 \mathrm{H}), 2.95(\mathrm{~s}$, $3 \mathrm{H}) .{ }^{13} \mathrm{C}$ NMR (126 MHz, DMSO) $\delta 164.72,163.63,157.97,140.85,139.07,138.84$, $128.29,128.29,128.25,127.47,126.84,125.94,122.31,115.31,44.39,38.54,32.66,15.43$. HRMS (ESI): calcd. 404.14327 for $\mathrm{C}_{23} \mathrm{H}_{22} \mathrm{~N}_{3} \mathrm{O}_{2} \mathrm{~S}$; found $404.1432[\mathrm{M}+\mathrm{H}]^{+}$.

\section{5-Methyl-2-phenethyl-4-(phenethylamino)thieno[2,3-d]pyrimidine-6-carboxylic acid (20)}

Isolated $28 \mathrm{mg}\left(60 \%\right.$ yield) as a white crystalline material. ${ }^{1} \mathrm{H}$ NMR $(500 \mathrm{MHz}, \mathrm{DMSO}) \delta$ $7.34-7.19$ (m, 9H), $7.17-7.13$ (m, 1H), 7.11 (br. t, $J=5.7 \mathrm{~Hz}, \mathrm{NH}$ ), 3.74 (dd, $J=14.6,6.0$ $\mathrm{Hz}, 2 \mathrm{H}), 3.11(\mathrm{dd}, J=8.5,6.3 \mathrm{~Hz}, 2 \mathrm{H}), 3.03(\mathrm{dd}, J=8.5,6.2 \mathrm{~Hz}, 2 \mathrm{H}), 2.95-2.89(\mathrm{~m}, 2 \mathrm{H})$, 2.81 (s, 3H). ${ }^{13} \mathrm{C}$ NMR (126 MHz, DMSO) $\delta 166.79,164.03,158.14,141.56,139.58$, $138.76,128.73,128.45,128.30,128.28,126.19,125.83,120.89,114.87,42.33,40.13$, 34.66, 33.37, 15.33. HRMS (ESI): calcd. 418.15892 for $\mathrm{C}_{24} \mathrm{H}_{24} \mathrm{~N}_{3} \mathrm{O}_{2} \mathrm{~S}$; found 418.1557 [M $+\mathrm{H}]^{+}$.

\section{4-((4-Methoxyphenethyl)amino)-5-methyl-2-phenethylthieno[2,3-d]pyrimidine-6-carboxylic acid (21)}

Isolated $36 \mathrm{mg}$ (55\% yield) as an off white powder. ${ }^{1} \mathrm{H}$ NMR (500 MHz, DMSO) $\delta 7.52(\mathrm{~m}$, $\mathrm{NH}), 7.27-7.22(\mathrm{~m}, 4 \mathrm{H}), 7.15(\mathrm{~m}, J=7.5 \mathrm{~Hz}, 3 \mathrm{H}), 6.86(\mathrm{~d}, J=8.7 \mathrm{~Hz}, 2 \mathrm{H}), 3.72(\mathrm{dd}, J=$ $14.3,6.4 \mathrm{~Hz}, 2 \mathrm{H}), 3.70(\mathrm{~s}, 3 \mathrm{H}), 3.13-3.09(\mathrm{~m}, 2 \mathrm{H}), 3.06(\mathrm{~m}, 2 \mathrm{H}), 2.87-2.82(\mathrm{~m}, 2 \mathrm{H}), 2.82$ (s, 3H). ${ }^{13} \mathrm{C}$ NMR (126 MHz, DMSO) $\delta 164.45,158.96,158.84,141.58,139.77,131.93$, 130.86, 129.57, 129.40, 127.30, 116.56, 115.02, 56.16, 44.42, 34.63, 33.54, 16.15. HRMS (ESI): calcd. 448.16949 for $\mathrm{C}_{25} \mathrm{H}_{26} \mathrm{~N}_{3} \mathrm{O}_{3} \mathrm{~S}$; found $448.1695[\mathrm{M}+\mathrm{H}]^{+}$. 
4-((3-Methoxyphenethyl)amino)-5-methyl-2-phenethylthieno[2,3-d]pyrimidine-6-carboxylic acid (22)

Isolated $45 \mathrm{mg}$ (68\% yield) as an off white powder. ${ }^{1} \mathrm{H}$ NMR (500 MHz, DMSO) $\delta 7.31$ (m, $\mathrm{NH}), 7.25-7.19(\mathrm{~m}, 5 \mathrm{H}), 7.16-7.12(\mathrm{~m}, 1 \mathrm{H}), 6.81(\mathrm{~m}, 2 \mathrm{H}), 6.77(\mathrm{~m}, 1 \mathrm{H}), 3.75(\mathrm{dd}, J=$ 14.0, $6.4 \mathrm{~Hz}, 2 \mathrm{H}), 3.69$ (s, $3 \mathrm{H}), 3.13-3.08(\mathrm{~m}, 2 \mathrm{H}), 3.06-3.01(\mathrm{~m}, 2 \mathrm{H}), 2.88(\mathrm{t}, J=7.4 \mathrm{~Hz}$, $2 \mathrm{H}), 2.81(\mathrm{~s}, 3 \mathrm{H}) .{ }^{13} \mathrm{C}$ NMR (126 MHz, DMSO) $\delta 164.79,160.49,159.06,142.11,141.96$, $139.82,130.61,129.49,129.39,127.13,122.13,116.29,115.49,112.80,56.01,43.78$, 35.68, 34.00, 16.28. HRMS (ESI): calcd. 448.16949 for $\mathrm{C}_{25} \mathrm{H}_{26} \mathrm{~N}_{3} \mathrm{O}_{3} \mathrm{~S}$; found 448.1684 [M $+\mathrm{H}]^{+}$.

\section{4-((2-Methoxyphenethyl)amino)-5-methyl-2-phenethylthieno[2,3-d]pyrimidine-6-carboxylic acid (23)}

Isolated $28 \mathrm{mg}\left(60 \%\right.$ yield) as an off white powder. ${ }^{1} \mathrm{H}$ NMR (500 MHz, DMSO) $\delta 7.26-$ $7.13(\mathrm{~m}, 7 \mathrm{H}, \mathrm{NH}), 6.95(\mathrm{~d}, J=7.7 \mathrm{~Hz}, 1 \mathrm{H}), 6.86(\mathrm{t}, J=7.3 \mathrm{~Hz}, 1 \mathrm{H}), 3.73(\mathrm{~m}, 5 \mathrm{H}), 3.10(\mathrm{~m}$, $2 \mathrm{H}), 3.01(\mathrm{~m}, 2 \mathrm{H}), 2.92(\mathrm{t}, J=7.1 \mathrm{~Hz}, 2 \mathrm{H}), 2.81(\mathrm{~s}, 3 \mathrm{H}) .{ }^{13} \mathrm{C}$ NMR $(126 \mathrm{MHz}, \mathrm{DMSO}) \delta$ $164.67,159.08,158.45,141.93,139.86,131.43,129.53,129.39,128.95,128.07,127.19$, 121.48, 116.36, 111.85, 56.38, 42.62, 33.72, 30.29, 16.20. HRMS (ESI): calcd. 448.16949 for $\mathrm{C}_{25} \mathrm{H}_{26} \mathrm{~N}_{3} \mathrm{O}_{3} \mathrm{~S}$; found $448.1681[\mathrm{M}+\mathrm{H}]^{+}$.

\section{4-((4-Fluorophenethyl)amino)-5-methyl-2-phenethylthieno[2,3-d]pyrimidine-6-carboxylic acid (24)}

Isolated $23 \mathrm{mg}$ (35\% yield) as an off white powder. ${ }^{1} \mathrm{H}$ NMR (500 MHz, DMSO) $\delta 7.28-$ $7.20(\mathrm{~m}, 5 \mathrm{H}, \mathrm{NH}), 7.12(\mathrm{~m}, 4 \mathrm{H}), 3.71(\mathrm{dd}, J=13.8,6.2 \mathrm{~Hz}, 2 \mathrm{H}), 3.11-3.06(\mathrm{~m}, 2 \mathrm{H}), 3.03-$ $2.98(\mathrm{~m}, 2 \mathrm{H}), 2.89$ (t, $J=7.4 \mathrm{~Hz}, 2 \mathrm{H}), 2.80$ (s, 3H). ${ }^{13} \mathrm{C}$ NMR (126 MHz, DMSO) $\delta$ 165.01, $162.00(\mathrm{~d}, J=241.5 \mathrm{~Hz}), 159.18,142.45,139.87,136.73(\mathrm{~d}, J=3.0 \mathrm{~Hz}), 131.63(\mathrm{~d}, J=7.9$ $\mathrm{Hz}), 129.44,129.40,127.01,116.24$ (d, $J=21.0 \mathrm{~Hz}), 116.08,43.52,34.82,34.30,16.41$. HRMS (ESI): calcd. 436.14950 for $\mathrm{C}_{24} \mathrm{H}_{23} \mathrm{FN}_{3} \mathrm{O}_{2} \mathrm{~S}$; found $436.1473[\mathrm{M}+\mathrm{H}]^{+}$.

\section{4-((3-Fluorophenethyl)amino)-5-methyl-2-phenethylthieno[2,3-d]pyrimidine-6-carboxylic acid (25)}

Isolated $30 \mathrm{mg}$ (46\% yield) as an off white powder. ${ }^{1} \mathrm{H}$ NMR (500 MHz, DMSO) $\delta 7.41(\mathrm{~m}$, $\mathrm{NH}), 7.32$ (dd, $J=14.4,7.8 \mathrm{~Hz}, 1 \mathrm{H}), 7.26-7.21(\mathrm{~m}, 4 \mathrm{H}), 7.16-7.12(\mathrm{~m}, 1 \mathrm{H}), 7.07(\mathrm{~m}$, $2 \mathrm{H}$ ), $7.02(\mathrm{td}, J=8.8,2.5 \mathrm{~Hz}, 1 \mathrm{H}), 3.77(\mathrm{dd}, J=13.9,6.3 \mathrm{~Hz}, 2 \mathrm{H}), 3.12-3.07(\mathrm{~m}, 2 \mathrm{H}), 3.06$ - $3.02(\mathrm{~m}, 2 \mathrm{H}), 2.93(\mathrm{t}, J=7.3 \mathrm{~Hz}, 2 \mathrm{H}), 2.81$ (s, 3H). ${ }^{13} \mathrm{C} \mathrm{NMR}(126 \mathrm{MHz}, \mathrm{DMSO}) \delta$ 164.44, 163.37 (d, $J=243.2 \mathrm{~Hz}), 158.87,143.12$ (d, $J=7.4 \mathrm{~Hz}), 141.59,139.72,131.41$ (d, $J=8.3 \mathrm{~Hz}), 129.54,129.39,127.28,126.12,126.10,124.37,116.64(\mathrm{~d}, J=14.6 \mathrm{~Hz})$, $116.54,114.25$ (d, $J=20.8 \mathrm{~Hz}), 43.76,38.43,35.12,33.58,16.14$. HRMS (ESI): calcd. 436.14950 for $\mathrm{C}_{24} \mathrm{H}_{23} \mathrm{FN}_{3} \mathrm{O}_{2} \mathrm{~S}$; found $436.1479[\mathrm{M}+\mathrm{H}]^{+}$.

\section{4-((2-Fluorophenethyl)amino)-5-methyl-2-phenethylthieno[2,3-d]pyrimidine-6-carboxylic acid (26)}

Isolated $21 \mathrm{mg}$ (32\% yield) as an off white powder. ${ }^{1} \mathrm{H}$ NMR (500 MHz, DMSO) $\delta 7.32-$ $7.19(\mathrm{~m}, 6 \mathrm{H}, \mathrm{NH}), 7.12(\mathrm{~m}, 3 \mathrm{H}), 3.76(\mathrm{dd}, J=13.8,6.7 \mathrm{~Hz}, 2 \mathrm{H}), 3.08(\mathrm{~m}, 2 \mathrm{H}), 3.02-2.93$ (m, 4H), 2.81 (s, 3H). ${ }^{13} \mathrm{C}$ NMR (126 MHz, DMSO) $\delta 164.90,161.97$ (d, $\left.J=243.3 \mathrm{~Hz}\right)$, 
$159.18,142.33,139.88,132.52(\mathrm{~d}, J=5.0 \mathrm{~Hz}), 129.59,129.53,129.47,129.39,127.10(\mathrm{~d}, J$ $=16.1 \mathrm{~Hz}), 127.06,125.55(\mathrm{~d}, J=3.3 \mathrm{~Hz}), 116.32(\mathrm{~d}, J=21.8 \mathrm{~Hz}), 116.16,42.24,34.08$, 29.25, 16.34. HRMS (ESI): calcd. 436.14950 for $\mathrm{C}_{24} \mathrm{H}_{23} \mathrm{FN}_{3} \mathrm{O}_{2} \mathrm{~S}$; found $436.1476[\mathrm{M}+\mathrm{H}]^{+}$.

\section{5-Methyl-4-((4-methylphenethyl)amino)-2-phenethylthieno[2,3-d]pyrimidine-6-carboxylic acid (27)}

Isolated $48 \mathrm{mg}$ (73\% yield) as an off white powder. ${ }^{1} \mathrm{H}$ NMR (500 MHz, DMSO) $\delta 7.33(\mathrm{~m}$, $\mathrm{NH}), 7.26-7.21(\mathrm{~m}, 4 \mathrm{H}), 7.16-7.09(\mathrm{~m}, 5 \mathrm{H}), 3.72(\mathrm{dd}, J=14.4,6.2 \mathrm{~Hz}, 2 \mathrm{H}), 3.12-3.08$ (m, 2H), $3.06-3.02(\mathrm{~m}, 2 \mathrm{H}), 2.88-2.83(\mathrm{~m}, 2 \mathrm{H}), 2.81(\mathrm{~s}, 3 \mathrm{H}), 2.25(\mathrm{~s}, 3 \mathrm{H}) .{ }^{13} \mathrm{C}$ NMR $(126$ MHz, DMSO) $\delta 164.64,158.94,141.90,139.78,137.16,136.36,130.15,129.73,129.52$, 129.38, 127.19, 116.37, 44.09, 35.17, 33.81, 21.80, 16.25. HRMS (ESI): calcd. 432.17457 for $\mathrm{C}_{25} \mathrm{H}_{26} \mathrm{~N}_{3} \mathrm{O}_{2} \mathrm{~S}$; found $432.1719[\mathrm{M}+\mathrm{H}]^{+}$.

\section{5-Methyl-4-((3-methylphenethyl)amino)-2-phenethylthieno[2,3-d]pyrimidine-6-carboxylic acid (28)}

Isolated $42 \mathrm{mg}$ (64\% yield) as an off white powder. ${ }^{1} \mathrm{H}$ NMR (500 MHz, DMSO) $\delta 7.45$ (m, $\mathrm{NH}), 7.25-7.22(\mathrm{~m}, 4 \mathrm{H}), 7.20-7.13(\mathrm{~m}, 2 \mathrm{H}), 7.07(\mathrm{~s}, 1 \mathrm{H}), 7.02(\mathrm{~m}, 2 \mathrm{H}), 3.74(\mathrm{dd}, J=$ 14.6, $6.1 \mathrm{~Hz}, 2 \mathrm{H}), 3.12(\mathrm{~m}, 2 \mathrm{H}), 3.06(\mathrm{~m}, 2 \mathrm{H}), 2.89-2.84(\mathrm{~m}, 2 \mathrm{H}), 2.81(\mathrm{~s}, 3 \mathrm{H}), 2.25(\mathrm{~s}$, $3 \mathrm{H}) .{ }^{13} \mathrm{C}$ NMR (126 MHz, DMSO) $\delta 164.43,158.82,141.57,140.02,139.73,138.61$, $130.58,129.56,129.50,129.38,128.09,127.30,126.94,116.59,44.26,38.35,35.44,33.55$, 22.15, 16.12. HRMS (ESI): calcd. 432.17457 for $\mathrm{C}_{25} \mathrm{H}_{26} \mathrm{~N}_{3} \mathrm{O}_{2} \mathrm{~S}$; found $432.1728[\mathrm{M}+\mathrm{H}]^{+}$.

\section{5-Methyl-4-((2-methylphenethyl)amino)-2-phenethylthieno[2,3-d]pyrimidine-6-carboxylic acid (29)}

Isolated $55 \mathrm{mg}$ (84\% yield) as an off white powder. ${ }^{1} \mathrm{H}$ NMR (500 MHz, DMSO) $\delta 7.42(\mathrm{~m}$, $\mathrm{NH}), 7.27-7.21(\mathrm{~m}, 4 \mathrm{H}), 7.17-7.12(\mathrm{~m}, 3 \mathrm{H}), 7.12-7.08(\mathrm{~m}, 2 \mathrm{H}), 3.68(\mathrm{dd}, J=15.5,5.8$ $\mathrm{Hz}, 2 \mathrm{H}), 3.11-3.06$ (m, 2H), $3.04-2.99$ (m, 2H), $2.93-2.88$ (m, 2H), 2.85 (s, 3H), 2.40 (s, 3H). ${ }^{13} \mathrm{C}$ NMR (126 MHz, DMSO) $\delta 164.75,159.07,142.05,139.79,138.43,137.20$, 131.24, 130.55, 129.52, 129.33, 127.51, 127.16, 127.08, 116.25, 42.76, 34.25, 33.47, 20.10, 16.39. HRMS (ESI): calcd. 432.17457 for $\mathrm{C}_{25} \mathrm{H}_{26} \mathrm{~N}_{3} \mathrm{O}_{2} \mathrm{~S}$; found $432.1746[\mathrm{M}+\mathrm{H}]^{+}$.

\section{5-Methyl-2-phenethyl-4-((2-(pyridin-4-yl)ethyl)amino)thieno[2,3-d]pyrimidine-6-carboxylic acid (30)}

Isolated $42 \mathrm{mg}$ (64\% yield) as a white powder. ${ }^{1} \mathrm{H}$ NMR (500 MHz, DMSO) $\delta 8.47$ (d, $J=$ $5.8 \mathrm{~Hz}, 2 \mathrm{H}), 7.28(\mathrm{~d}, J=5.7 \mathrm{~Hz}, 2 \mathrm{H}), 7.25-7.20(\mathrm{~m}, 4 \mathrm{H}), 7.13(\mathrm{~m}, \mathrm{NH}, 1 \mathrm{H}), 3.77(\mathrm{dd}, J=$ $13.4,6.6 \mathrm{~Hz}, 2 \mathrm{H}), 3.09-3.05(\mathrm{~m}, 2 \mathrm{H}), 3.00(\mathrm{~m}, 2 \mathrm{H}), 2.93(\mathrm{t}, J=7.2 \mathrm{~Hz}, 2 \mathrm{H}), 2.80(\mathrm{~s}$, $3 \mathrm{H}) .{ }^{13} \mathrm{C}$ NMR (126 MHz, DMSO) $\delta 168.00,167.89,165.14,159.23,150.30,142.65$, 139.84, 129.42, 129.41, 126.95, 125.59, 122.11, 116.00, 42.20, 41.19, 35.03, 34.47, 16.48 . HRMS (ESI): calcd. 419.15417 for $\mathrm{C}_{23} \mathrm{H}_{23} \mathrm{~N}_{4} \mathrm{O}_{2} \mathrm{~S}$; found $419.1537[\mathrm{M}+\mathrm{H}]^{+}$.

\section{5-Methyl-2-phenethyl-4-((2-(pyridin-3-yl)ethyl)amino)thieno[2,3-d]pyrimidine-6-carboxylic acid (31)}

Isolated $41 \mathrm{mg}$ (87\% yield) as a white powder. ${ }^{1} \mathrm{H}$ NMR (500 MHz, DMSO) $\delta 8.45(\mathrm{~s}, 1 \mathrm{H})$, $8.40(\mathrm{~d}, J=4.7 \mathrm{~Hz}, 1 \mathrm{H}), 7.63(\mathrm{~d}, J=7.8 \mathrm{~Hz}, 1 \mathrm{H}), 7.30$ (dd, $J=7.7,4.8 \mathrm{~Hz}, 1 \mathrm{H}), 7.25-7.20$ 
(m, 4H), $7.13(\mathrm{~m}, 1 \mathrm{H}, \mathrm{NH}), 3.75(\mathrm{dd}, J=13.3,6.7 \mathrm{~Hz}, 2 \mathrm{H}), 3.07$ (dd, $J=8.4,6.1 \mathrm{~Hz}, 2 \mathrm{H})$, 2.99 (dd, $J=8.5,6.3 \mathrm{~Hz}, 2 \mathrm{H}), 2.92$ (t, $J=7.2 \mathrm{~Hz}, 2 \mathrm{H}), 2.80$ (s, 3H). ${ }^{13} \mathrm{C}$ NMR $(126 \mathrm{MHz}$, DMSO) $\delta 168.00,167.89,165.15,159.25,151.01,148.56,142.67,139.82,137.49,136.22$, 129.41, 126.94, 124.63, 122.11, 115.97, 42.86, 41.23, 34.49, 32.89, 16.47. HRMS (ESI): calcd. 419.15417 for $\mathrm{C}_{23} \mathrm{H}_{23} \mathrm{~N}_{4} \mathrm{O}_{2} \mathrm{~S}$; found $419.1537[\mathrm{M}+\mathrm{H}]^{+}$.

\section{5-Methyl-2-phenethyl-4-((2-(pyridin-2-yl)ethyl)amino)thieno[2,3-d]pyrimidine-6-carboxylic acid (32)}

Isolated $57 \mathrm{mg}$ (87\% yield) as an off white solid. ${ }^{1} \mathrm{H}$ NMR (500 MHz, DMSO) $\delta 8.56$ (d, $J$ $=4.9 \mathrm{~Hz}, 1 \mathrm{H}), 7.83(\mathrm{~m}, \mathrm{NH}), 7.41-7.32(\mathrm{~m}, 3 \mathrm{H}), 7.24-7.21(\mathrm{~m}, 4 \mathrm{H}), 7.15-7.11(\mathrm{~m}, 1 \mathrm{H})$, $3.89(\mathrm{dd}, J=12.4,6.6 \mathrm{~Hz}, 2 \mathrm{H}), 3.12(\mathrm{t}, J=6.7 \mathrm{~Hz}, 2 \mathrm{H}), 3.05(\mathrm{~m}, 2 \mathrm{H}), 2.96(\mathrm{~m}, 2 \mathrm{H}), 2.84(\mathrm{~s}$, $3 \mathrm{H}) .{ }^{13} \mathrm{C}$ NMR (126 MHz, DMSO) $\delta 167.80,165.14,159.92,159.17,148.62,142.70$, $139.82,139.46,129.42,129.38,126.90,125.32,123.35,122.12,115.99,41.44,41.17$, 36.77, 34.40, 16.42. MS (ESI): calcd. 419.15417 for $\mathrm{C}_{23} \mathrm{H}_{23} \mathrm{~N}_{4} \mathrm{O}_{2} \mathrm{~S}$; found 419.1545 [M $+\mathrm{H}]^{+}$

\section{2-(4-Acetamidophenethyl)-5-methyl-4-(methylamino)thieno[2,3-d]pyrimidine-6-carboxylic acid (33)}

Isolated $27 \mathrm{mg}$ (72\% yield) as an off white powder. ${ }^{1} \mathrm{H}$ NMR (500 MHz, DMSO) $\delta 9.85$ (s, NHAc), $7.46(\mathrm{~m}, \mathrm{NH}), 7.44$ (d, $J=8.3 \mathrm{~Hz}, 2 \mathrm{H}), 7.15(\mathrm{~d}, J=8.3 \mathrm{~Hz}, 2 \mathrm{H}), 3.03(\mathrm{~m}, 7 \mathrm{H}), 2.87$ (s, 3H), 1.99 (s, 3H). ${ }^{13} \mathrm{C}$ NMR (126 MHz, DMSO) $\delta 169.25,164.47,159.15,139.96$, 138.66, 136.03, 129.62, 124.20, 120.16, 116.72, 38.55, 33.04, 30.12, 25.10, 16.22. HRMS (ESI): calcd. 385.13344 for $\mathrm{C}_{19} \mathrm{H}_{21} \mathrm{~N}_{4} \mathrm{O}_{3} \mathrm{~S}$; found $385.1336[\mathrm{M}+\mathrm{H}]^{+}$.

\section{2-(3-Acetamidophenethyl)-5-methyl-4-(methylamino)thieno[2,3-d]pyrimidine-6-carboxylic acid (34)}

Isolated $23 \mathrm{mg}$ (62\% yield) as a white powder. ${ }^{1} \mathrm{H}$ NMR (500 MHz, DMSO) $\delta 9.84$ (s, NHAc), 7.47 (s, 1H), 7.37 (d, $J=8.3 \mathrm{~Hz}, 1 \mathrm{H}), 7.15(\mathrm{t}, J=7.8 \mathrm{~Hz}, 1 \mathrm{H}), 7.08(\mathrm{~m}, \mathrm{NH}), 6.90$ $(\mathrm{d}, J=7.9 \mathrm{~Hz}, 1 \mathrm{H}), 3.05-2.94(\mathrm{~m}, 7 \mathrm{H}), 2.86(\mathrm{~s}, 3 \mathrm{H}), 2.00(\mathrm{~s}, 3 \mathrm{H}) .{ }^{13} \mathrm{C} \mathrm{NMR}(126 \mathrm{MHz}$, DMSO) $\delta 169.33,167.60,165.14,159.80,143.12,140.46,140.07,129.69,124.16,121.93$, $120.00,117.75,116.19,34.57,29.33,25.18,16.55$. HRMS (ESI): calcd. 385.13344 for $\mathrm{C}_{19} \mathrm{H}_{21} \mathrm{~N}_{4} \mathrm{O}_{3} \mathrm{~S}$; found $385.1333[\mathrm{M}+\mathrm{H}]^{+}$.

\section{2-(2-Acetamidophenethyl)-5-methyl-4-(methylamino)thieno[2,3-d]pyrimidine-6-carboxylic acid (35)}

Isolated $13 \mathrm{mg}$ (46\% yield) as an off white powder. ${ }^{1} \mathrm{H}$ NMR (500 MHz, DMSO) $\delta 9.40$ (s, NHAc), 7.32 (d, $J=7.8 \mathrm{~Hz}, 1 \mathrm{H}), 7.25(\mathrm{~d}, J=7.6 \mathrm{~Hz}, 1 \mathrm{H}), 7.14(\mathrm{~m}, \mathrm{NH}), 7.08(\mathrm{~m}, 2 \mathrm{H}), 3.08$ $-3.02(\mathrm{~m}, 2 \mathrm{H}), 2.98(\mathrm{~d}, J=4.4 \mathrm{~Hz}, 3 \mathrm{H}), 2.96-2.91(\mathrm{~m}, 2 \mathrm{H}), 2.86(\mathrm{~s}, 3 \mathrm{H}), 2.04(\mathrm{~s}, 3 \mathrm{H}) .{ }^{13} \mathrm{C}$ NMR (126 MHz, DMSO) $\delta 169.54,168.12,165.17,159.83,140.10,137.22,136.98,130.26$, 127.28, 126.57, 121.82, 116.18, 30.04, 29.25, 24.42, 16.58. HRMS (ESI): calcd. 385.13344 for $\mathrm{C}_{19} \mathrm{H}_{21} \mathrm{~N}_{4} \mathrm{O}_{3} \mathrm{~S}$; found $385.1331[\mathrm{M}+\mathrm{H}]^{+}$. 
4-((2,3-Dihydro-1H-inden-2-yl)amino)-5-methyl-2-phenethylthieno[2,3-d]pyrimidine-6carboxylic acid (36)

Isolated $47 \mathrm{mg}$ (72\% yield) as an off white powder. ${ }^{1} \mathrm{H}$ NMR (500 MHz, DMSO) $\delta 7.25-$ 7.19 (m, 5H, NH), $7.17-7.12(\mathrm{~m}, 3 \mathrm{H}), 6.91(\mathrm{~d}, J=7.0 \mathrm{~Hz}, 1 \mathrm{H}), 5.07-4.98(\mathrm{~m}, 1 \mathrm{H}), 3.36-$ $3.28(\mathrm{~m}, 2 \mathrm{H}), 3.09-3.04$ (m, 3H), 3.01 (m, 3H), 2.87 (s, 3H). ${ }^{13} \mathrm{C}$ NMR (126 MHz, DMSO) $\delta 168.05,167.84,165.15,159.46,142.65,142.33,140.06,129.41,129.37,127.58,126.91$, 125.53, 122.21, 116.24, 53.03, 41.21, 39.86, 34.49, 16.39. HRMS (ESI): calcd. 430.15892 for $\mathrm{C}_{25} \mathrm{H}_{24} \mathrm{~N}_{3} \mathrm{O}_{2} \mathrm{~S}$; found $430.1562[\mathrm{M}+\mathrm{H}]^{+}$.

4-((3,5-Dimethoxyphenethyl)amino)-5-methyl-2-phenethylthieno[2,3-d]pyrimidine-6carboxylic acid (37)

Isolated $31 \mathrm{mg}\left(82 \%\right.$ yield) as an off white powder. ${ }^{1} \mathrm{H}$ NMR (500 MHz, DMSO) $\delta 7.24-$ $7.22(\mathrm{~m}, 4 \mathrm{H}), 7.16-7.09(\mathrm{~m}, 1 \mathrm{H}, \mathrm{NH}), 6.41(\mathrm{~d}, J=2.2 \mathrm{~Hz}, 2 \mathrm{H}), 6.33(\mathrm{t}, J=2.2 \mathrm{~Hz}, 1 \mathrm{H})$, $3.73(\mathrm{dd}, J=14.5,6.4 \mathrm{~Hz}, 2 \mathrm{H}), 3.67(\mathrm{~s}, 6 \mathrm{H}), 3.10(\mathrm{~m}, 2 \mathrm{H}), 3.01(\mathrm{~m}, 2 \mathrm{H}), 2.87-2.82(\mathrm{~m}$, 2H), 2.81 (s, 3H). ${ }^{13} \mathrm{C}$ NMR (126 MHz, DMSO) $\delta 165.08,161.61,159.21,142.94,142.57$, $139.84,129.42,129.38,126.99,116.05,107.83,99.15,56.13,43.42,36.02,34.40,16.41$. MS (ESI): calcd. 478.18005 for $\mathrm{C}_{26} \mathrm{H}_{28} \mathrm{~N}_{3} \mathrm{O}_{4} \mathrm{~S}$; found $478.1782[\mathrm{M}+\mathrm{H}]^{+}$.

4-((2-(Benzo[d][1,3]dioxol-5-yl)ethyl)amino)-5-methyl-2-phenethylthieno[2,3-d]pyrimidine-6carboxylic acid (38)

Isolated $22 \mathrm{mg}$ (47\% yield) as a white solid. ${ }^{1} \mathrm{H}$ NMR (500 MHz, DMSO) $\delta 7.27-7.18(\mathrm{~m}$, $5 \mathrm{H}, \mathrm{NH}), 7.16-7.12(\mathrm{~m}, 1 \mathrm{H}), 6.82(\mathrm{~m}, 2 \mathrm{H}), 6.68(\mathrm{dd}, J=7.9,1.6 \mathrm{~Hz}, 1 \mathrm{H}), 5.95(\mathrm{~s}, 2 \mathrm{H})$, $3.70(\mathrm{dd}, J=14.0,6.0 \mathrm{~Hz}, 1 \mathrm{H}), 3.13-3.06(\mathrm{~m}, 2 \mathrm{H}), 3.02(\mathrm{~m}, 2 \mathrm{H}), 2.85-2.78(\mathrm{~m}, 5 \mathrm{H}) .{ }^{13} \mathrm{C}$ NMR (126 MHz, DMSO) $\delta 164.83,159.07,148.43,146.76,142.18,139.85,134.16,129.49$, 129.40, 127.12, 122.76, 116.24, 110.19, 109.33, 101.86, 43.92, 35.33, 34.07, 16.31. HRMS (ESI): calcd. 462.14875 for $\mathrm{C}_{25} \mathrm{H}_{24} \mathrm{~N}_{3} \mathrm{O}_{4} \mathrm{~S}$; found $462.1486[\mathrm{M}+\mathrm{H}]^{+}$.

5-Methyl-4-(methylamino)-2-(3-phenylpropyl)thieno[2,3-d]pyrimidine-6-carboxylic acid (39) Isolated $36 \mathrm{mg}$ (78\% yield) as a white powder. ${ }^{1} \mathrm{H}$ NMR (500 MHz, DMSO) $\delta 7.25$ (m, $2 \mathrm{H}), 7.19(\mathrm{~m}, 2 \mathrm{H}), 7.14(\mathrm{~m}, 1 \mathrm{H}, \mathrm{NH}), 2.97(\mathrm{~d}, J=4.4 \mathrm{~Hz}, 3 \mathrm{H}), 2.84(\mathrm{~s}, 3 \mathrm{H}), 2.69$ (t, $J=7.5$ $\mathrm{Hz}, 2 \mathrm{H}), 2.62$ (t, $J=7.6 \mathrm{~Hz}, 2 \mathrm{H}), 2.05-1.97(\mathrm{~m}, 2 \mathrm{H}) .{ }^{13} \mathrm{C} \mathrm{NMR}(126 \mathrm{MHz}, \mathrm{DMSO}) \delta$ 168.13, 165.10, 159.76, 143.09, 140.03, 129.53, 129.38, 126.84, 121.96, 116.11, 38.83, 35.90, 30.49, 29.34, 16.50. MS (ESI): calcd 342.12762 for $\mathrm{C}_{18} \mathrm{H}_{20} \mathrm{~N}_{3} \mathrm{O}_{2} \mathrm{~S}$; found 342.1256 $[\mathrm{M}+\mathrm{H}]^{+}$.

\section{5-Methyl-4-(methylamino)-2-(4-phenylbutyl)thieno[2,3-d]pyrimidine-6-carboxylic acid (40)}

Isolated $60 \mathrm{mg}$ (86\% yield) as white powder. ${ }^{1} \mathrm{H}$ NMR (500 MHz, DMSO) $\delta 7.23$ (t, $J=7.5$ $\mathrm{Hz}, 2 \mathrm{H}), 7.13$ (m, 3H), 7.03 (br. m, NH), 2.94 (d, $J=4.4 \mathrm{~Hz}, 3 \mathrm{H}), 2.84$ (s, 3H), 2.69 (t, $J=$ $7.5 \mathrm{~Hz}, 2 \mathrm{H}), 2.58(\mathrm{t}, J=7.6 \mathrm{~Hz}, 2 \mathrm{H}), 1.76-1.68(\mathrm{~m}, 2 \mathrm{H}), 1.63-1.55(\mathrm{~m}, 2 \mathrm{H}) .{ }^{13} \mathrm{C}$ NMR (126 MHz, DMSO) $\delta 168.72,167.39,165.17,159.83,143.33,140.06,129.42,129.34$, $126.74,121.71,116.03,39.49,36.12,31.86,29.21,28.41,16.53$. HRMS (ESI): calcd 356.14327 for $\mathrm{C}_{19} \mathrm{H}_{22} \mathrm{~N}_{3} \mathrm{O}_{2} \mathrm{~S}$; found $356.1413[\mathrm{M}+\mathrm{H}]^{+}$. 
2-(3-Methoxyphenethyl)-5-methyl-4-(methylamino)thieno[2,3-d]pyrimidine-6-carboxylic acid (41)

Isolated $66 \mathrm{mg}$ (71\% yield) as a white powder. ${ }^{1} \mathrm{H}$ NMR (500 MHz, DMSO) $\delta 7.12$ (t, $J=$ $8.0 \mathrm{~Hz}, 1 \mathrm{H}), 7.01(\mathrm{~m}, \mathrm{NH}), 6.77(\mathrm{~m}, 2 \mathrm{H}), 6.68(\mathrm{dd}, J=9.0,1.6 \mathrm{~Hz}, 1 \mathrm{H}), 3.05-2.93(\mathrm{~m}, 7 \mathrm{H})$, 2.82 (s, 3H). OC $H_{3}$ signal obscured by water peak. ${ }^{13} \mathrm{C}$ NMR (126 MHz, DMSO) $\delta 167.90$, $167.48,165.15,160.29,159.80,144.29,140.03,130.39,121.82,121.70,116.09,115.03$, 112.39, 55.95, 41.03, 34.37, 29.19, 16.48. MS (ESI): calc. 358.12254 for $\mathrm{C}_{18} \mathrm{H}_{20} \mathrm{~N}_{3} \mathrm{O}_{3} \mathrm{~S}$; found $358.1208[\mathrm{M}+\mathrm{H}]^{+}$.

2-(3-Fluorophenethyl)-5-methyl-4-(methylamino)thieno[2,3-d]pyrimidine-6-carboxylic acid (42)

Isolated $77 \mathrm{mg}$ (83\% yield) as a white powder. ${ }^{1} \mathrm{H}$ NMR (500 MHz, DMSO) $\delta 7.24(\mathrm{~m}$, $1 \mathrm{H}), 7.02(\mathrm{~m}, 2 \mathrm{H}, \mathrm{NH}), 6.93(\mathrm{~m}, 1 \mathrm{H}), 3.06(\mathrm{t}, J=7.5 \mathrm{~Hz}, 2 \mathrm{H}), 3.00-2.95(\mathrm{~m}, 2 \mathrm{H}), 2.94(\mathrm{~d}$, $J=4.5 \mathrm{~Hz}, 3 \mathrm{H}), 2.81(\mathrm{~s}, 3 \mathrm{H}) .{ }^{13} \mathrm{C}$ NMR $(126 \mathrm{MHz}$, DMSO) $\delta 167.64,167.50,165.14$, $163.28(\mathrm{~d}, \mathrm{~J}=242.8 \mathrm{~Hz}), 159.77,145.69(\mathrm{~d}, \mathrm{~J}=7.3 \mathrm{~Hz}), 140.01,131.16(\mathrm{~d}, \mathrm{~J}=8.4 \mathrm{~Hz})$, $125.58(\mathrm{~d}, \mathrm{~J}=2.6 \mathrm{~Hz}), 121.85,116.12(\mathrm{~d}, \mathrm{~J}=20.7 \mathrm{~Hz}), 116.09,113.65(\mathrm{~d}, \mathrm{~J}=20.9 \mathrm{~Hz})$, 40.65, 33.89, 29.17, 16.47. HRMS (ESI): calcd. 346.10255 for $\mathrm{C}_{17} \mathrm{H}_{17} \mathrm{FN}_{3} \mathrm{O}_{2} \mathrm{~S}$; found $346.1006[\mathrm{M}+\mathrm{H}]^{+}$.

\section{5-Methyl-4-(methylamino)-2-(2-(pyridin-2-yl)ethyl)thieno[2,3-d]pyrimidine-6-carboxylic acid (43) \\ Isolated $46 \mathrm{mg}$ (84\% yield) as a white powder. ${ }^{1} \mathrm{H}$ NMR (300 MHz, DMSO) $\delta 8.75(\mathrm{~d}, J=$ $4.9 \mathrm{~Hz}, 1 \mathrm{H}), 8.41(\mathrm{td}, J=7.9,1.5 \mathrm{~Hz}, 1 \mathrm{H}), 7.95(\mathrm{~d}, J=8.0 \mathrm{~Hz}, 1 \mathrm{H}), 7.82(\mathrm{t}, J=6.3 \mathrm{~Hz}, 1 \mathrm{H})$, 7.17 (br. m, NH), 3.47 (t, $J=7.1 \mathrm{~Hz}, 2 \mathrm{H}), 3.27$ (t, $J=7.1 \mathrm{~Hz}, 2 \mathrm{H}), 2.80(\mathrm{~m}, 6 \mathrm{H}) .{ }^{13} \mathrm{C}$ NMR (75 MHz, DMSO) $\delta 165.80,165.33,164.51,159.13,157.64,146.10,142.19,139.47$, 127.38, 125.11, 121.94, 115.76, 36.57, 31.33, 28.73, 15.89. HRMS (ESI): calcd. 329.10722 for $\mathrm{C}_{16} \mathrm{H}_{17} \mathrm{~N}_{4} \mathrm{O}_{2} \mathrm{~S}$; found $329.1067[\mathrm{M}+\mathrm{H}]^{+}$.}

\section{2-(4-Acetamidophenethyl)-4-((2-aminoethyl)amino)-5-methylthieno[2,3-d]pyrimidine-6- carboxylic acid (44)}

Isolated $17 \mathrm{mg}$ (36\% yield) as a white powder. ${ }^{1} \mathrm{H}$ NMR (500 MHz, DMSO) $\delta 9.84$ (s, NHAc), 8.50 (br. s, $\mathrm{NH}_{2}$ ), 7.56 (br. s, NH), 7.44 (d, $\left.J=8.3 \mathrm{~Hz}, 2 \mathrm{H}\right), 7.15$ (d, $J=8.4 \mathrm{~Hz}, 2 \mathrm{H}$ ), $3.82(\mathrm{~m}, 2 \mathrm{H}), 3.15(\mathrm{~m}, 2 \mathrm{H}), 3.03(\mathrm{~s}, 3 \mathrm{H}), 3.00(\mathrm{~d}, J=7.2 \mathrm{~Hz}, 2 \mathrm{H}), 2.94(\mathrm{~d}, J=7.8 \mathrm{~Hz}, 2 \mathrm{H})$, 2.00 (s, 3H). HRMS (ESI): calcd. 414.15999 for $\mathrm{C}_{20} \mathrm{H}_{24} \mathrm{~N}_{5} \mathrm{O}_{3} \mathrm{~S}$; found $414.1591[\mathrm{M}+\mathrm{H}]^{+}$.

\section{2-(4-Acetamidophenethyl)-5-methyl-4-((2-(pyridin-2-yl)ethyl)amino)thieno[2,3- d]pyrimidine-6-carboxylic acid (45)}

Isolated $33 \mathrm{mg}$ (64\% yield) as a white powder. ${ }^{1} \mathrm{H}$ NMR (500 MHz, DMSO) $\delta 9.83(\mathrm{~s}, \mathrm{NH})$, $8.51(\mathrm{~d}, J=4.9 \mathrm{~Hz}, 1 \mathrm{H}), 7.71(\mathrm{tt}, J=7.7,1.9 \mathrm{~Hz}, 1 \mathrm{H}), 7.42(\mathrm{~d}, J=6.8 \mathrm{~Hz}, 2 \mathrm{H}), 7.36$ (br. t, $J$ $=4.8 \mathrm{~Hz}, \mathrm{NH}), 7.28(\mathrm{~d}, J=7.8 \mathrm{~Hz}, 1 \mathrm{H}), 7.25-7.20(\mathrm{~m}, 1 \mathrm{H}), 7.13(\mathrm{~d}, J=6.9 \mathrm{~Hz}, 2 \mathrm{H}), 3.87$ (dd, $J=12.2,5.5 \mathrm{~Hz}, 2 \mathrm{H}), 3.08(\mathrm{t}, J=6.5 \mathrm{~Hz}, 2 \mathrm{H}), 3.04-2.99(\mathrm{~m}, 2 \mathrm{H}), 2.97-2.93(\mathrm{~m}, 2 \mathrm{H})$, $2.85(\mathrm{~s}, 3 \mathrm{H}), 1.99$ (s, 3H). ${ }^{13} \mathrm{C}$ NMR (126 MHz, DMSO) $\delta 169.20,167.80,165.22,160.73$, 159.22, 150.13, 138.30, 137.87, 137.25, 129.57, 124.49, 122.79, 120.13, 116.03, 41.56, 
41.31, 37.42, 33.89, 25.07, 16.32. HRMS (ESI): calcd. 476.17564 for $\mathrm{C}_{25} \mathrm{H}_{26} \mathrm{~N}_{5} \mathrm{O}_{3} \mathrm{~S}$; found $476.1761[\mathrm{M}+\mathrm{H}]^{+}$

2-(3-Chlorophenethyl)-5-methyl-4-(methylamino)thieno[2,3-d]pyrimidine-6-carboxylic acid (46)

Isolated $62 \mathrm{mg}$ (67\% yield) as a white powder. ${ }^{1} \mathrm{H}$ NMR (500 MHz, DMSO) $\delta 7.28(\mathrm{~s}, 1 \mathrm{H})$, $7.25-7.21(\mathrm{~m}, 1 \mathrm{H}), 7.18-7.14(\mathrm{~m}, 2 \mathrm{H}), 7.03(\mathrm{~m}, \mathrm{NH}), 3.07-3.02(\mathrm{~m}, 2 \mathrm{H}), 2.97(\mathrm{~m}, 2 \mathrm{H})$, $2.94(\mathrm{~d}, J=4.5 \mathrm{~Hz}, 3 \mathrm{H}), 2.81$ (s, 3H). ${ }^{13} \mathrm{C}$ NMR $(126 \mathrm{MHz}$, DMSO) $\delta 167.47,167.21$, $165.11,159.74,145.25,140.00,133.93,131.16,129.37,128.21,126.90,121.93,116.10$, 40.51, 33.75, 29.20, 16.46. HRMS (ESI): calcd. 362.07300 for $\mathrm{C}_{17} \mathrm{H}_{17} \mathrm{ClN}_{3} \mathrm{O}_{2} \mathrm{~S}$; found $362.0719[\mathrm{M}+\mathrm{H}]^{+}$.

\section{5-Methyl-4-(methylamino)-2-(3-(trifluoromethyl)phenethyl)thieno[2,3-d]pyrimidine-6- carboxylic acid (47)}

Isolated $80 \mathrm{mg}$ (86\% yield) as a white powder. ${ }^{1} \mathrm{H}$ NMR (500 MHz, DMSO) $\delta 7.55(\mathrm{~s}, 1 \mathrm{H})$, 7.46 (m, 3H), 7.04 (br. m, NH), 3.14 (t, $J=7.5 \mathrm{~Hz}, 2 \mathrm{H}$ ), 3.02 (t, $J=7.5 \mathrm{~Hz}, 2 \mathrm{H}), 2.92$ (d, $J=$ $4.4 \mathrm{~Hz}, 3 \mathrm{H}), 2.81(\mathrm{~s}, 3 \mathrm{H}) .{ }^{13} \mathrm{C}$ NMR (126 MHz, DMSO) $\delta 167.36,167.13,165.10,159.73$, $144.05,139.97,133.66,130.31,130.16,129.91, \delta 126.06$ (q, $J=3.8 \mathrm{~Hz}), 123.66$ (q, $J=3.9$ $\mathrm{Hz}), 121.96,116.09,33.79,29.14$, 16.44. HRMS (ESI): calcd. 396.09936 for $\mathrm{C}_{18} \mathrm{H}_{17} \mathrm{~F}_{3} \mathrm{~N}_{3} \mathrm{O}_{2} \mathrm{~S}$; found $396.0975[\mathrm{M}+\mathrm{H}]^{+}$.

\section{2-(2-(Benzo[d][1,3]dioxol-5-yl)ethyl)-5-methyl-4-(methylamino)thieno[2,3-d]pyrimidine-6- carboxylic acid (48)}

Isolated $25 \mathrm{mg}$ (54\% yield) as white solid. ${ }^{1} \mathrm{H}$ NMR (500 MHz, DMSO) $\delta 7.13$ (br. s, NH), $6.82(\mathrm{~s}, 1 \mathrm{H}), 6.77$ (d, $J=7.9 \mathrm{~Hz}, 1 \mathrm{H}), 6.67$ (d, $J=7.9 \mathrm{~Hz}, 1 \mathrm{H}), 5.93(\mathrm{~s}, 2 \mathrm{H}), 3.02-2.93$ (m, $7 \mathrm{H}), 2.86(\mathrm{~s}, 3 \mathrm{H}) .{ }^{13} \mathrm{C}$ NMR (126 MHz, DMSO) $\delta 167.45,165.09,159.73,148.25,146.39$, 140.07, 136.42, 122.21, 122.05, 116.18, 109.95, 109.18, 101.72, 41.21, 34.01, 29.36, 16.53 . HRMS (ESI): calcd. 372.10180 for $\mathrm{C}_{18} \mathrm{H}_{18} \mathrm{~N}_{3} \mathrm{O}_{4} \mathrm{~S}$; found $372.1021[\mathrm{M}+\mathrm{H}]^{+}$.

\section{4-(methylamino)-2-phenethylthieno[3,2-d]pyrimidine-6-carboxylic acid (49)}

Isolated $40 \mathrm{mg}$ (84\% yield) as an off-white powder. ${ }^{1} \mathrm{H}$ NMR (500 MHz, DMSO) $\delta 7.99(\mathrm{~m}$, $\mathrm{NH}), 7.81(\mathrm{~s}, 1 \mathrm{H}), 7.27-7.23(\mathrm{~m}, 4 \mathrm{H}), 7.16(\mathrm{~m}, 1 \mathrm{H}), 3.12-3.07(\mathrm{~m}, 2 \mathrm{H}), 3.05-3.01(\mathrm{~m}$, 2H), 2.99 (d, $J=4.0 \mathrm{~Hz}, 3 \mathrm{H}) .{ }^{13} \mathrm{C}$ NMR (126 MHz, DMSO) $\delta 167.38,164.21,158.49$, 142.88, 130.23, 129.48, 129.39, 126.90, 41.32, 34.82, 28.44. HRMS (ESI): calcd. 314.09632 for $\mathrm{C}_{16} \mathrm{H}_{16} \mathrm{~N}_{3} \mathrm{O}_{2} \mathrm{~S}$; found $314.0962[\mathrm{M}+\mathrm{H}]^{+}$.

\section{2-(3-Methoxyphenethyl)-4-(methylamino)thieno[3,2-d]pyrimidine-6-carboxylic acid (50)}

Isolated $78 \mathrm{mg}$ ( $81 \%$ yield) as a white powder. ${ }^{1} \mathrm{H}$ NMR (500 MHz, DMSO) $\delta 8.11$ (br. d, $J$ $=4.3 \mathrm{~Hz}, 1 \mathrm{H}), 7.76(\mathrm{~s}, 1 \mathrm{H}), 7.13(\mathrm{t}, J=7.8 \mathrm{~Hz}, 1 \mathrm{H}), 6.81-6.75(\mathrm{~m}, 2 \mathrm{H}), 6.68(\mathrm{dd}, J=8.3$, $1.7 \mathrm{~Hz}, 1 \mathrm{H}), 3.04-2.99(\mathrm{~m}, 4 \mathrm{H}), 2.97(\mathrm{~d}, J=4.4 \mathrm{~Hz}, 3 \mathrm{H})$. OC $H_{3}$ signal obscured by water peak. ${ }^{13} \mathrm{C}$ NMR (126 MHz, DMSO) $\delta$ 167.10, 164.14, 160.30, 144.29, 130.40, 129.32, 121.72, 121.68, 115.03, 112.40, 55.95, 40.79, 34.69. HRMS (ESI): calcd. 344.10689 for $\mathrm{C}_{17} \mathrm{H}_{18} \mathrm{~N}_{3} \mathrm{O}_{3} \mathrm{~S}$; found $344.1072[\mathrm{M}+\mathrm{H}]^{+}$. 


\section{Ethyl 4-(((R)-2-methoxy-2-phenylethyl)amino)-5-methyl-2-((S)-2-phenylpropyl)thieno[2,3- d]pyrimidine-6-carboxylate - 51 (precursor)}

Isolated $101 \mathrm{mg}$ (53\% yield) as a colorless syrup. ${ }^{1} \mathrm{H}$ NMR (500 MHz, DMSO) $\delta 7.38(\mathrm{~m}$, 2H), $7.34-7.28(\mathrm{~m}$, ), $7.22(\mathrm{~m}, 5 \mathrm{H}), 7.10(\mathrm{t}, J=6.8 \mathrm{~Hz}, 1 \mathrm{H}), 6.96$ (br. t, $J=5.5 \mathrm{~Hz}, \mathrm{NH}$ ), $4.54(\mathrm{dd}, J=7.5,5.3 \mathrm{~Hz}, 1 \mathrm{H}), 4.27(\mathrm{q}, J=7.1 \mathrm{~Hz}, 2 \mathrm{H}), 3.76-3.69(\mathrm{~m}, 1 \mathrm{H}), 3.69-3.61(\mathrm{~m}$, $1 \mathrm{H}), 3.43(\mathrm{~m}, 1 \mathrm{H}), 3.18(\mathrm{~s}, 3 \mathrm{H}), 2.96(\mathrm{~m}, 2 \mathrm{H}), 2.76(\mathrm{~s}, 3 \mathrm{H}), 1.28(\mathrm{t}, J=7.1 \mathrm{~Hz}, 3 \mathrm{H}), 1.20(\mathrm{~d}$, $J=6.9 \mathrm{~Hz}, 3 \mathrm{H}) .{ }^{13} \mathrm{C}$ NMR $(75 \mathrm{MHz}$, DMSO) $\delta 167.65,167.15,162.87,158.58,147.31$, $140.51,140.03,129.07,128.85,128.46,127.41,127.19,126.50,120.06,115.15,81.57$, 79.84, 61.61, 57.16, 47.51, 39.04, 22.62, 15.94, 14.75. MS (ESI): calcd. 490.22; found $490.33[\mathrm{M}+\mathrm{H}]^{+}$.

\section{4-(((R)-2-methoxy-2-phenylethyl)amino)-5-methyl-2-((S)-2-phenylpropyl)thieno[2,3- d]pyrimidine-6-carboxylic acid (51)}

Isolated $13 \mathrm{mg}$ (28\% yield) as white solid. ${ }^{1} \mathrm{H}$ NMR (500 MHz, DMSO) $\delta 7.38(\mathrm{~m}, 2 \mathrm{H})$, $7.31(\mathrm{~m}, 3 \mathrm{H}), 7.22(\mathrm{~m}, 4 \mathrm{H}), 7.12-7.08(\mathrm{~m}, 1 \mathrm{H}), 6.85$ (br. s, NH), $4.54(\mathrm{~m}, 1 \mathrm{H}), 3.72(\mathrm{~m}$, $1 \mathrm{H}), 3.68-3.60(\mathrm{~m}, 1 \mathrm{H}), 3.18(\mathrm{~s}, 3 \mathrm{H}), 3.02-2.86(\mathrm{~m}, 3 \mathrm{H}), 2.75(\mathrm{~s}, 3 \mathrm{H}), 1.20(\mathrm{~d}, J=6.9 \mathrm{~Hz}$, $3 \mathrm{H}) .{ }^{13} \mathrm{C}$ NMR (126 MHz, DMSO) $\delta 167.68,167.10,165.30,159.07,147.85,141.06$, $129.60,129.40,128.99,127.97,127.75,127.04,115.94,82.06,57.70,47.98,47.61,39.57$, 23.21, 16.17. HRMS (ESI): calcd. 462.18514 for $\mathrm{C}_{26} \mathrm{H}_{28} \mathrm{~N}_{3} \mathrm{O}_{3} \mathrm{~S}$; found $462.1853[\mathrm{M}+\mathrm{H}]^{+}$

\section{Ethyl 4-(((S)-2-methoxy-2-phenylethyl)amino)-5-methyl-2-((S)-2-phenylpropyl)thieno[2,3- d]pyrimidine-6-carboxylate 52 (precursor)}

Isolated $31 \mathrm{mg}$ (16\% yield) as a colorless syrup. ${ }^{1} \mathrm{H}$ NMR (500 MHz, DMSO) $\delta 7.41-7.36$ (m, 2H), $7.31(\mathrm{~m}, 3 \mathrm{H}), 7.25-7.20(\mathrm{~m}, 4 \mathrm{H}), 7.10(\mathrm{~m}, 1 \mathrm{H}), 6.99$ (br. t, $J=5.4 \mathrm{~Hz}, \mathrm{NH}), 4.51$ $(\mathrm{dd}, J=7.8,4.7 \mathrm{~Hz}, 1 \mathrm{H}), 4.27(\mathrm{q}, J=7.1 \mathrm{~Hz}, 2 \mathrm{H}), 3.79-3.73(\mathrm{~m}, 1 \mathrm{H}), 3.62(\mathrm{~m}, 1 \mathrm{H}), 3.44$ (m, 1H), $3.17(\mathrm{~s}, 3 \mathrm{H}), 2.95(\mathrm{~m}, 2 \mathrm{H}), 2.78(\mathrm{~s}, 3 \mathrm{H}), 1.28(\mathrm{t}, J=7.1 \mathrm{~Hz}, 3 \mathrm{H}), 1.22(\mathrm{~d}, J=7.0$ $\mathrm{Hz}, 3 \mathrm{H}) .{ }^{13} \mathrm{C}$ NMR $(75 \mathrm{MHz}, \mathrm{DMSO}) \delta 167.62,167.17,162.90,158.60,147.27,140.52$, $140.12,129.11,128.88,128.51,127.45,127.20,126.54,120.05,115.17,81.63,61.68$, 57.21, 47.49, 36.87, 24.96, 22.71, 16.00, 14.80. MS (ESI): calcd. 490.22; found 490.40 [M $+\mathrm{H}]^{+}$.

\section{4-(((S)-2-Methoxy-2-phenylethyl)amino)-5-methyl-2-((S)-2-phenylpropyl)thieno[2,3- d]pyrimidine-6-carboxylic acid (52)}

Isolated $15 \mathrm{mg}$ (53\% yield) as a white solid. ${ }^{1} \mathrm{H}$ NMR (500 MHz, DMSO) $\delta 7.39(\mathrm{~m}, 2 \mathrm{H})$, $7.31(\mathrm{~m}, 3 \mathrm{H}), 7.21(\mathrm{~m}, 4 \mathrm{H}), 7.10(\mathrm{~m}, 1 \mathrm{H}), 6.97(\mathrm{~m}, \mathrm{NH}), 4.51(\mathrm{dd}, J=7.7,4.4 \mathrm{~Hz}, 1 \mathrm{H}), 3.76$ (m, 1H), $3.62(\mathrm{~m}, 1 \mathrm{H}), 3.17(\mathrm{~s}, 3 \mathrm{H}), 2.95(\mathrm{~m}, 3 \mathrm{H}), 2.77(\mathrm{~s}, 3 \mathrm{H}), 1.22(\mathrm{~d}, J=6.9 \mathrm{~Hz}, 3 \mathrm{H}) .{ }^{13} \mathrm{C}$ NMR (126 MHz, DMSO) $\delta$ 167.30, 165.07, 159.10, 147.75, 141.02, 139.64, 129.62, 129.40, 129.02, 127.97, 127.73, 127.07, 122.30, 115.88, 82.12, 57.72, 47.89, 47.70, 39.49, 23.24, 16.32. HRMS (ESI): calcd. 462.18514 for $\mathrm{C}_{26} \mathrm{H}_{28} \mathrm{~N}_{3} \mathrm{O}_{3} \mathrm{~S}$; found $462.1857[\mathrm{M}+\mathrm{H}]^{+}$.

\section{Ethyl 4-(((R)-2-methoxy-2-phenylethyl)amino)-5-methyl-2-((R)-2-phenylpropyl)thieno[2,3- d]pyrimidine-6-carboxylate 53 (precursor)}

Isolated $65 \mathrm{mg}$ (63\% yield) as pale yellow syrup. ${ }^{1} \mathrm{H}$ NMR $\left(300 \mathrm{MHz}, \mathrm{CDCl}_{3}\right) \delta 7.46-7.20$ (m, 9H), $7.16-7.09$ (m, 1H), 6.11 (br. t, NH), $4.41-4.31$ (m, 3H), 4.08 (ddd, $J=13.8,7.2$, 
$4.0 \mathrm{~Hz}, 1 \mathrm{H}), 3.56-3.44(\mathrm{~m}, 2 \mathrm{H}), 3.30(\mathrm{~s}, 3 \mathrm{H}), 3.17-2.96(\mathrm{~m}, 2 \mathrm{H}), 2.87$ (s, 3H), 1.39 (t, $J=$ $7.1 \mathrm{~Hz}, 3 \mathrm{H}), 1.29$ (d, $J=7.0 \mathrm{~Hz}, 3 \mathrm{H}) .{ }^{13} \mathrm{C}$ NMR $\left(75 \mathrm{MHz}, \mathrm{CDCl}_{3}\right) \delta 163.33,158.77$, 147.18, 139.30, 138.36, 128.97, 128.57, 128.47, 127.27, 126.87, 126.13, 115.37, 82.07, $61.45,57.25,47.11,39.30,24.96,22.09,15.71,14.56$. MS (ESI): calcd. 490.22; found $490.33[\mathrm{M}+\mathrm{H}]^{+}$.

4-(((R)-2-Methoxy-2-phenylethyl)amino)-5-methyl-2-((R)-2-phenylpropyl)thieno[2,3d]pyrimidine-6-carboxylic acid (53)

Isolated $43 \mathrm{mg}$ (76\% yield) as white solid. ${ }^{1} \mathrm{H}$ NMR (500 MHz, DMSO) $\delta 7.39(\mathrm{~m}, 2 \mathrm{H})$, $7.31(\mathrm{~m}, 3 \mathrm{H}), 7.25-7.18(\mathrm{~m}, 4 \mathrm{H}), 7.12-7.07(\mathrm{~m}, 1 \mathrm{H}), 7.04$ ( br. t, $J=5.4 \mathrm{~Hz}, \mathrm{NH}), 4.50$ $(\mathrm{dd}, J=7.9,4.7 \mathrm{~Hz}, 1 \mathrm{H}), 3.80-3.73(\mathrm{~m}, 1 \mathrm{H}), 3.66-3.61(\mathrm{~m}, 1 \mathrm{H}), 3.17(\mathrm{~s}, 3 \mathrm{H}), 2.96(\mathrm{~m}$, $4 \mathrm{H}), 2.77$ (s, 3H), 1.22 (d, $J=7.0 \mathrm{~Hz}, 3 \mathrm{H}) .{ }^{13} \mathrm{C}$ NMR (126 MHz, DMSO) $\delta$ 167.06, 165.01, 159.08, 147.65, 140.95, 139.63, 129.63, 129.42, 129.04, 127.96, 127.73, 127.10, 122.47, 115.92, 82.10, 68.17, 57.72, 47.73, 39.47, 23.22, 16.28. HRMS (ESI): calcd. 462.18514 for $\mathrm{C}_{26} \mathrm{H}_{28} \mathrm{~N}_{3} \mathrm{O}_{3} \mathrm{~S}$; found $462.1847[\mathrm{M}+\mathrm{H}]^{+}$.

\section{Ethyl 4-(((S)-2-methoxy-2-phenylethyl)amino)-5-methyl-2-((R)-2-phenylpropyl)thieno[2,3- d]pyrimidine-6-carboxylate 54 (precursor)}

Isolated $67 \mathrm{mg}$ (65\% yield) as a colorless syrup. ${ }^{1} \mathrm{H}$ NMR $\left(300 \mathrm{MHz}, \mathrm{CDCl}_{3}\right) \delta 7.46-7.32$ (m, 5H), $7.30-7.19(\mathrm{~m}, 4 \mathrm{H}), 7.13$ (dt, $J=9.3,4.2 \mathrm{~Hz}, 1 \mathrm{H}), 6.11$ (br. t, NH), 4.39 (m, 3H), 4.06 (ddd, $J=13.7,7.0,4.1 \mathrm{~Hz}, 1 \mathrm{H}), 3.57-3.44(\mathrm{~m}, 2 \mathrm{H}), 3.31(\mathrm{~s}, 3 \mathrm{H}), 3.08(\mathrm{~m}, 2 \mathrm{H}), 2.87$ (s, 3H), $1.38(\mathrm{t}, J=6.2 \mathrm{~Hz}, 3 \mathrm{H}), 1.27(\mathrm{~d}, J=6.9 \mathrm{~Hz}, 3 \mathrm{H}) .{ }^{13} \mathrm{C} \mathrm{NMR}\left(75 \mathrm{MHz}, \mathrm{CDCl}_{3}\right) \delta$ $163.33,158.78,147.22,139.29,138.35,128.97,128.57,128.47,127.26,126.88,126.12$, $115.37,82.06,61.45,57.24,47.06,39.28,36.93,22.18,15.68,14.55$. MS (ESI): calcd. 490.22; found $490.33[\mathrm{M}+\mathrm{H}]^{+}$.

\section{4-(((S)-2-Methoxy-2-phenylethyl)amino)-5-methyl-2-((R)-2-phenylpropyl)thieno[2,3- d]pyrimidine-6-carboxylic acid (54)}

Isolated $42 \mathrm{mg}$ (74\% yield) as a yellow solid. ${ }^{1} \mathrm{H}$ NMR (500 MHz, DMSO) $\delta 7.41-7.36$ (m, 2H), $7.34-7.29(\mathrm{~m}, 3 \mathrm{H}), 7.26-7.19(\mathrm{~m}, 4 \mathrm{H}), 7.12-7.08$ (m, 1H), 7.00 (br. t, $J=5.5$ $\mathrm{Hz}, \mathrm{NH}), 4.54(\mathrm{dd}, J=7.6,5.1 \mathrm{~Hz}, 1 \mathrm{H}), 3.76-3.70(\mathrm{~m}, 1 \mathrm{H}), 3.69-3.62(\mathrm{~m}, 1 \mathrm{H}), 3.18(\mathrm{~s}$, 3H), 2.96 (m, 3H), 2.75 (s, 3H), 1.20 (d, $J=7.0 \mathrm{~Hz}, 3 \mathrm{H}) .{ }^{13} \mathrm{C}$ NMR (126 MHz, DMSO) $\delta$ $167.12,165.02,159.09,147.68,140.96,139.62,129.62,129.43,129.04,127.96,127.75$, 127.10, 122.45, 115.91, 82.02, 68.17, 57.70, 47.71, 39.55, 23.20, 16.25. HRMS (ESI): calcd. 462.18514 for $\mathrm{C}_{26} \mathrm{H}_{28} \mathrm{~N}_{3} \mathrm{O}_{3} \mathrm{~S}$; found $462.1847[\mathrm{M}+\mathrm{H}]^{+}$.

\section{Ethyl (S)-2-(4-acetamidophenethyl)-4-((2-methoxy-2-phenylethyl)amino)-5-methylthieno[2,3- d]pyrimidine-6-carboxylate 55 (precursor)}

Isolated $40 \mathrm{mg}$ (82\% yield, over two steps) as a white powder. ${ }^{1} \mathrm{H} \mathrm{NMR}\left(300 \mathrm{MHz}, \mathrm{CDCl}_{3}\right)$ $\delta 7.55(\mathrm{~s}, 1 \mathrm{H}), 7.41(\mathrm{~m}, 7 \mathrm{H}), 7.15$ (d, $J=8.4 \mathrm{~Hz}, 2 \mathrm{H}), 6.16$ (br. m, NH), 4.43 (dd, $J=8.6$, $3.8 \mathrm{~Hz}, 1 \mathrm{H}), 4.34(\mathrm{q}, J=7.1 \mathrm{~Hz}, 2 \mathrm{H}), 4.14$ (ddd, $J=14.0,7.0,4.3 \mathrm{~Hz}, 1 \mathrm{H}), 3.54$ (ddd, $J=$ 13.7, 8.7, 3.8 Hz, 1H), 3.31 (s, 3H), 3.07 (m, 4H), 2.88 (s, 3H), 2.12 (s, 3H), 1.38 (t, $J=7.1$ $\mathrm{Hz}, 4 \mathrm{H}) .{ }^{13} \mathrm{C} \mathrm{NMR}\left(75 \mathrm{MHz}, \mathrm{CDCl}_{3}\right) \delta 163.32,158.91,150.73,137.95,129.11,128.98$, 
126.87, 120.18, 115.46, 84.48, 61.49, 57.24, 47.08, 41.08, 33.87, 24.72, 15.72, 14.55. MS

(ESI): calcd. 533.22; found 533.27[M+H] $]^{+}$.

\section{(S)-2-(4-Acetamidophenethyl)-4-((2-methoxy-2-phenylethyl)amino)-5-methylthieno[2,3- d]pyrimidine-6-carboxylic acid (55)}

Isolated $24 \mathrm{mg}$ (63\% yield) as a white powder. ${ }^{1} \mathrm{H}$ NMR (500 MHz, DMSO) $\delta 9.81$ (s, NHAc), 7.43 (d, $J=8.5 \mathrm{~Hz}, 2 \mathrm{H}), 7.39-7.28(\mathrm{~m}, 5 \mathrm{H}), 7.12$ (d, $J=8.5 \mathrm{~Hz}, 2 \mathrm{H}), 6.98$ (br. t, $J$ $=5.2 \mathrm{~Hz}, \mathrm{NH}), 4.54(\mathrm{dd}, J=7.7,5.0 \mathrm{~Hz}, 1 \mathrm{H}), 3.80(\mathrm{~m}, 1 \mathrm{H}), 3.67(\mathrm{~m}, 1 \mathrm{H}), 3.18(\mathrm{~s}, 3 \mathrm{H}), 2.98$ (m, 4H), 2.79 (s, 3H), 1.98 (s, 3H). ${ }^{13} \mathrm{C}$ NMR (126 MHz, DMSO) $\delta 169.15,167.82,165.09$, $159.21,141.02,139.66,138.37,137.11,129.61,129.55,129.00,127.75,122.32,120.10$, 115.96, 82.14, 57.69, 47.66, 41.28, 33.91, 25.08, 16.33. HRMS (ESI): calcd. 505.19095 for $\mathrm{C}_{27} \mathrm{H}_{29} \mathrm{~N}_{4} \mathrm{O}_{4} \mathrm{~S}$; found $505.1916[\mathrm{M}+\mathrm{H}]^{+}$.

\section{Protein expression and purification}

The heterologous expression of PglD was accomplished using the E. coli BL-21(DE3) strain (Stratagene). Cells were transformed with pETNO-construct plasmids and grown to an A600 of 0.6 absorbance units at $37^{\circ} \mathrm{C}$ in Lysogeny broth; the cultures were cooled to $16{ }^{\circ} \mathrm{C}$ and then induced by the addition of $0.5 \mathrm{mM}$ isopropyl-D-thiogalactopyranoside (IPTG). The pETNO plasmid is based on the pET30a plasmid modified to include a His 8 TEV (purification tag/protease cleavage site) in place of the existing His $_{6}$-thrombin site. Twenty hours after induction the cells were harvested by centrifugation and resuspended in ice-cold buffer composed of $50 \mathrm{mM}$ HEPES pH 7.1, $10 \mathrm{mM}$ imidazole, $150 \mathrm{mM} \mathrm{NaCl}$, at1/20 the original culture volume. Maintaining a working temperature of $4{ }^{\circ} \mathrm{C}$, the cells were lysed by sonication, and the lysate was cleared by centrifugation in a Type 45 Ti rotor (Beckman/ Coulter) at 35,000 rpm. The extract was bound to Ni-NTA (Qiagen) in batch mode using 1 $\mathrm{mL}$ of resin per liter of culture for $1 \mathrm{~h}$ with gentle tumbling. The protein-bound resin was washed with 25 column volumes of lysis buffer containing $50 \mathrm{mM}$ imidazole, and the protein was eluted in lysis buffer containing $250 \mathrm{mM}$ imidazole. The hexahistidine tag was removed by TEV cleavage, and after the digest reached completion, the reaction was dialyzed twice against $4 \mathrm{~L} 20 \mathrm{mM}$ HEPES pH 7.1, $150 \mathrm{mM} \mathrm{NaCl}$ with a 10,000 MWCO Snakeskin (Thermo Scientific). Further purification was performed by size exclusion chromatography using a Superdex 200 XK16-60 column (GE Healthcare) in a running buffer of $20 \mathrm{mM}$ HEPES pH 7.1, $100 \mathrm{mM} \mathrm{NaCl}$.

\section{High-throughput screening - Broad Institute MLPCN}

To a Nunc 384-well black-clear bottom plate (Thermo Scientific) was added $200 \mathrm{~nL}$ of compound in neat DMSO (final assay concentration $=10 \mu \mathrm{M}$ ) and $20 \mu \mathrm{L}$ of enzyme solution (final assay concentrations: $6 \mathrm{nM}$ PglD, $50 \mathrm{mM}$ HEPES pH 7.4, 0.001\% Triton, 0.05\% BSA, $100 \mu \mathrm{M}$ AcCoA). Solution dispensing was accomplished utilizing a Multidrop Combi (Thermo Scientific). This mixture was allowed to incubate at room temperature for a duration of 45 minutes. The reaction was started by the addition of $10 \mu \mathrm{L}$ reaction solution (final assay concentrations: $50 \mathrm{mM}$ HEPES pH7.4, $100 \mu \mathrm{M}$ UDP-4-aminosugar). The reaction was quenched after 30 minutes with the addition of $30 \mu \mathrm{L}$ stop solution (final assay concentrations: $2 \mathrm{mM}$ DTNB, $1 \mathrm{mM}$ EDTA, 20\% 1-propanol). The plates were allowed to develop for 5 minutes before reading at a $\lambda=405 \mathrm{~nm}$. 


\section{Enzymatic inhibition assay}

Kinetic characterization of PglD inhibition was carried out by monitoring CoASH release resulting from the acetyltransferase reaction with Ellman's reagent (DTNB) in a continuous fashion. To a flat, clear bottom 96-well plate (Falcon) was added sequentially the inhibitor as a DMSO stock solution, followed by PgID in $50 \mathrm{mM}$ HEPES pH 7.8, $1 \mathrm{mM} \mathrm{MgCl}_{2}, 0.05$ $\mathrm{mg} / \mathrm{mL}$ BSA, $0.001 \%$ Triton X-100. Inhibitors and enzyme were pre-incubated $30 \mathrm{~min}$ at RT, followed by addition of substrate and Ellman's reagent cocktail to final concentrations of $3 \mathrm{nM}$ PglD, $500 \mu \mathrm{M}$ 4-amino-sugar, $300 \mu \mathrm{M}$ AcCoA, $2 \mathrm{mM}$ DTNB and 3\% DMSO in $150 \mu \mathrm{L}$ volume. Initial rates were measured in the linear portion of the reaction curve over a 5 min time period at RT, measuring absorbance at $412 \mathrm{~nm}$ on a Synergy H1 hybrid plate reader from Biotek.

\section{Dynamic Light Scattering}

Samples were prepared in buffer $50 \mathrm{mM}$ HEPES 7.5, $100 \mathrm{mM} \mathrm{NaCl}$ and a final concentration of 3\% DMSO; the concentration of $C$ jejuni PglD was $25 \mu \mathrm{M}$ with or without $250 \mu \mathrm{M}$ inhibitor 57. DLS data was acquired on a Wyatt DynaPro Nanostar Light Scatterer by measuring scattering at a $90^{\circ}$ angle with a $685 \mathrm{~nm}$ laser and analyzed with a Rayleigh scattering model using the Dynamics 7.1.9 software package.

\section{Differential Scanning Fluorimetry}

Samples were prepared to a final volume of $25 \mu \mathrm{L}$ containing $10 \mu \mathrm{M}$ PglD protein and 100 $\mu \mathrm{M}$ inhibitor in a buffer containing $50 \mathrm{mM}$ HEPES 7.5, $150 \mathrm{mM} \mathrm{NaCl}, 0.001 \%$ Triton $\mathrm{X}-100,10 \times$ Sypro orange (diluted from a commercial stock solution of 5000X; Invitrogen) and a final concentration of $3 \%$ DMSO. All samples were prepared in duplicate.

Fluorescence was measured using a Roche Lightcycler 480 RT-PCR instrument while increasing the temperature gradient from 30 to $95^{\circ} \mathrm{C}$ in increments of $4.4^{\circ} \mathrm{C} / 60 \mathrm{~s}$. The midpoint temperature of the unfolding protein transition $\left(\mathrm{T}_{\mathrm{m}}\right)$ was calculated using the builtin functionality of the instrument software package.

\section{Crystallization of C. jejuni PgID in complex with inhibitor 17}

Initial crystallization screening was performed by sitting drop vapor diffusion using intelliplate ${ }^{\circledR}$ from Hampton Research with $50 \mu \mathrm{L} /$ well solution, which was dispensed as a $0.15 \mu \mathrm{L}$ drop followed $0.15 \mu \mathrm{L}$ of $10 \mathrm{mg} / \mathrm{mL}$ PglD solution in SEC buffer. Screens used were PEG suite 1, PEG suite 2, PACT and ProComp from Qiagen, and drops were set up using an Art Robbins Phoenix robot. Diffraction quality crystals were formed via hanging drop vapor diffusion by mixing $1.5 \mu \mathrm{L}$ of protein solution with $1.5 \mu \mathrm{L}$ of reservoir solution (15\% PEG-3350, 0.1M NaF and 10\% glycerol) and incubation at $22{ }^{\circ} \mathrm{C}$.

Ligand soaking: Wells were carefully opened and $50 \mu \mathrm{L}$ of DMSO was added directly to the well; $0.75 \mu \mathrm{L}$ of a solution containing $10 \mathrm{mM}$ inhibitor $\mathbf{1 7}$ in reservoir solution (final concentration of $10 \%$ DMSO) was added directly to the drops on the slide. The crystals were then incubated for $30 \mathrm{~min}$ to 3 days, and then looped and flash frozen in liquid nitrogen without the need of separate cryoprotection. 


\section{Data Collection, Processing, and Structure Refinement}

Diffraction data was collected either at a home source (Rigaku Saturn 944 with

MicroMax-007 HF and VariMax HF generator) or at the Advanced Photon Source (APS) at Argonne National Laboratory (in Argonne, Illinois, USA) national synchrotron on the NECAT-24ID beamline. The diffraction data were indexed and scaled with either HKL2000. The initial structure model was built by applying molecular replacement methods with a ligand/solvent-omitted input model generated from the PDB model 3BSY. The initial models were further improved through iterative rounds of manual and automated refinement with COOT. ${ }^{56}$ The final structure has been deposited into the Protein Data Bank PDB ID 5T2Y. Data collection and refinement statistics are presented in in the supporting information Table S3

\section{Supplementary Material}

Refer to Web version on PubMed Central for supplementary material.

\section{Acknowledgments}

We thank Dr. K. Rajashankar and the staff at NECAT-24ID (APS) for facilitating X-ray data collection for the 5T2Y structure and Dr. Alexei Soares (BNL) for the 5TYH structure, Dr. Robert Grant (MIT) and Dr. Nelson Olivier for technical assistance with protein crystallography and data processing and Dr. James Spoonamore (Broad Institute) for the MLPCN screening. We also thank Drs. Amael Madec and Cristina Zamora for their valuable assistance with the preparation of this manuscript. Financial support for this work was provided by NIH (R01GM097241 \& R03-MH096549 to BI), the Belgian American Education Foundation (fellowship to J.W.D.S.) and the Homerton College, Cambridge (Junior Research Fellowship to A.C.). Part of this work is based upon research conducted at the Northeastern Collaborative Access Team beamline 24-ID-E, which is funded by the National Institute of General Medical Sciences from the National Institutes of Health (P41 GM103403). This research used resources of the Advanced Photon Source, a U.S. Department of Energy (DOE) Office of Science User Facility operated for the DOE Office of Science by Argonne National Laboratory under Contract No. DEAC02-06CH11357.

\section{Abbreviations}

AcCoA acetyl coenzyme A

BOP (Benzotriazol-1-yloxy)tris(dimethylamino)phosphonium hexafluorophosphate

DBU 1,8-Diazabicyclo[5.4.0]undec-7-ene

diNAcBac 2,4-diacetamido-2,4,6-trideoxy-a-D-glucose

PyBOP (Benzotriazol-1-yloxy)tripyrrolidinophosphonium hexafluorophosphate

DSF Differential scanning fluorimetry

DLS dynamic light scattering

PLP Pyridoxal $5^{\prime}$-phosphate

STD saturation transfer difference

UndP undecaprenyl phosphate 


\section{References}

1. Silver LL. Challenges of Antibacterial Discovery. Clin Microbiol Rev. 2011; 24:71-109. [PubMed: 21233508]

2. Clatworthy AE, Pierson E, Hung DT. Targeting Virulence: A New Paradigm for Antimicrobial Therapy. Nat Chem Biol. 2007; 3:541-548. [PubMed: 17710100]

3. Baron C. Antivirulence Drugs to Target Bacterial Secretion Systems. Curr Opin Microbiol. 2010; 13:100-105. [PubMed: 20079679]

4. Barczak AK, Hung DT. Productive Steps Toward an Antimicrobial Targeting Virulence. Curr Opin Microbiol. 2009; 12:490-496. [PubMed: 19631578]

5. Cegelski L, Marshall GR, Eldridge GR, Hultgren SJ. The Biology and Future Prospects of Antivirulence Therapies. Nat Rev Micro. 2008; 6:17-27.

6. Ohtsubo K, Marth JD. Glycosylation in Cellular Mechanisms of Health and Disease. Cell. 2006; 126:855-867. [PubMed: 16959566]

7. Nothaft H, Szymanski CM. Bacterial Protein N-glycosylation: New Perspectives and Applications. J Biol Chem. 2013; 288:6912-6920. [PubMed: 23329827]

8. Aas FE, Vik Å, Vedde J, Koomey M, Egge-Jacobsen W. Neisseria gonorrhoeae O-linked Pilin Glycosylation: Functional Analyses Define Both the bBosynthetic Pathway and Glycan Structure. Mol Microbiol. 2007; 65:607-624. [PubMed: 17608667]

9. Benz I, Schmidt MA. Never Say Never Again: Protein Glycosylation in Pathogenic Bacteria. Mol Microbiol. 2002; 45:267-276. [PubMed: 12123443]

10. Szymanski CM, Wren BW. Protein Glycosylation in Bacterial Mucosal Pathogens. Nat Rev Micro. 2005; 3:225-237.

11. Vik Å, Aas FE, Anonsen JH, Bilsborough S, Schneider A, Egge-Jacobsen W, Koomey M. Broad Spectrum O-Linked Protein Glycosylation in the Human Pathogen Neisseria gonorrhoeae. Proc Natl Acad Sci U S A. 2009; 106:4447-4452. [PubMed: 19251655]

12. Szymanski CM, Yao R, Ewing CP, Trust TJ, Guerry P. Evidence for a System of General Protein Glycosylation in Campylobacter jejuni. Mol Microbiol. 1999; 32:1022-1030. [PubMed: 10361304]

13. Nothaft H, Szymanski CM. Protein Glycosylation in Bacteria: Sweeter Than Ever. Nat Rev Micro. 2010; 8:765-778.

14. Scott NE, Parker BL, Connolly AM, Paulech J, Edwards AVG, Crossett B, Falconer L, Kolarich D, Djordjevic SP, Højrup P, Packer NH, Larsen MR, Cordwell SJ. Simultaneous Glycan-Peptide Characterization Using Hydrophilic Interaction Chromatography and Parallel Fragmentation by CID, Higher Energy Collisional Dissociation, and Electron Transfer Dissociation MS Applied to the N-Linked Glycoproteome of Campylobacter jejuni. Mol Cell Proteomics. 2011; 10:M000031MCP000201. [PubMed: 20360033]

15. Schmidt MA, Riley LW, Benz I. Sweet New World: Glycoproteins in Bacterial Pathogens. Trends Microbiol. 2003; 11:554-561. [PubMed: 14659687]

16. Sharon N. Celebrating the Golden Anniversary of the Discovery of Bacillosamine, the Diamino Sugar of a Bacillus. Glycobiology. 2007; 17:1150-1155. [PubMed: 17717023]

17. Morrison MJ, Imperiali B. The Renaissance of Bacillosamine and Its Derivatives: Pathway Characterization and Implications in Pathogenicity. Biochemistry. 2014; 53:624-638. [PubMed: 24383882]

18. Olivier NB, Chen MM, Behr JR, Imperiali B. In Vitro Biosynthesis of UDP-N,N' Diacetylbacillosamine by Enzymes of the Campylobacter jejuni General Protein Glycosylation System $†$. Biochemistry. 2006; 45:13659-13669. [PubMed: 17087520]

19. Hartley MD, Morrison MJ, Aas FE, Børud B, Koomey M, Imperiali B. Biochemical Characterization of the O-Linked Glycosylation Pathway in Neisseria gonorrhoeae Responsible for Biosynthesis of Protein Glycans Containing N,N'-Diacetylbacillosamine. Biochemistry. 2011; 50:4936-4948. [PubMed: 21542610]

20. Morrison MJ, Imperiali B. Biosynthesis of UDP-N,N'-Diacetylbacillosamine in Acinetobacter baumannir: Biochemical Characterization and Correlation to Existing Pathways. Arch Biochem Biophys. 2013; 536:72-80. [PubMed: 23747578] 
21. Kelly J, Jarrell H, Millar L, Tessier L, Fiori LM, Lau PC, Allan B, Szymanski CM. Biosynthesis of the N-Linked Glycan in Campylobacter jejuni and Addition onto Protein through Block Transfer. J Bacteriol. 2006; 188:2427-2434. [PubMed: 16547029]

22. Hendrixson DR, DiRita VJ. Identification of Campylobacter jejuni Genes Involved in Commensal Colonization of the Chick Gastrointestinal Tract. Mol Microbiol. 2004; 52:471-484. [PubMed: 15066034]

23. Szymanski CM, Burr DH, Guerry P. Campylobacter Protein Glycosylation Affects Host Cell Interactions. Inf Immun. 2002; 70:2242-2244.

24. Larsen JC, Szymanski C, Guerry P. N-Linked Protein Glycosylation Is Required for Full Competence in Campylobacter jejuni 81-176. J Bacteriol. 2004; 186:6508-6514. [PubMed: 15375132]

25. Elmi A, Watson E, Sandu P, Gundogdu O, Mills DC, Inglis NF, Manson E, Imrie L, Bajaj-Elliott M, Wren BW, Smith DG, Dorrell N. Campylobacter jejuni Outer Membrane Vesicles Play an Important Role in Bacterial Interactions with Human Intestinal Epithelial Cells. Infect Immun. 2012; 80:4089-4098. [PubMed: 22966047]

26. Ellis TN, Kuehn MJ. Virulence and Immunomodulatory Roles of Bacterial Outer Membrane Vesicles. Microbiol Mol Biol Rev. 2010; 74:81-94. [PubMed: 20197500]

27. Jennings MP, Jen FEC, Roddam LF, Apicella MA, Edwards JL. Neisseria gonorrhoeae Pilin Glycan Contributes to CR3 Activation During Challenge of Primary Cervical Epithelial Cells. Cell Microbiol. 2011; 13:885-896. [PubMed: 21371235]

28. Olivier NB, Imperiali B. Crystal Structure and Catalytic Mechanism of PglD from Campylobacter jejuni. J Biol Chem. 2008; 283:27937-27946. [PubMed: 18667421]

29. Rangarajan ES, Ruane KM, Sulea T, Watson DC, Proteau A, Leclerc S, Cygler M, Matte A, Young NM. Structure and Active Site Residues of PgID, an N-Acetyltransferase from the Bacillosamine Synthetic Pathway Required for N-Glycan Synthesis in Campylobacter jejuni. Biochemistry. 2008; 47:1827-1836. [PubMed: 18198901]

30. Vetting MW, LPSdC, Yu M, Hegde SS, Magnet S, Roderick SL, Blanchard JS. Structure and Functions of the GNAT Superfamily of Acetyltransferases. Arch Biochem Biophys. 2005; 433:212-226. [PubMed: 15581578]

31. Aspinall GO, McDonald AG, Pang H, Kurjanczyk LA, Penner JL. Lipopolysaccharides of Campylobacter jejuni Serotype O:19: Structures of Core Oligosaccharide Regions from the Serostrain and Two Bacterial Isolates from Patients with the Guillain-Barre Syndrome. Biochemistry. 1994; 33:241-249. [PubMed: 8286348]

32. Allos BM, Lippy FT, Carlsen A, Washburn RG, Blaser MJ. Campylobacter jejuni Strains from Patients with Guillain-Barre Syndrome. Emerg Infect Disease. 1998; 4:263-268. [PubMed: 9621196]

33. Luangtongkum T, Jeon B, Han J, Plummer P, Logue CM, Zhang Q. Antibiotic Resistance in Campylobacter: Emergence, Transmission and Persistence. Fut Microbiol. 2009; 4:189-200.

34. Scott DE, Coyne AG, Hudson SA, Abell C. Fragment-Based Approaches in Drug Discovery and Chemical Biology. Biochemistry. 2012; 51:4990-5003. [PubMed: 22697260]

35. Silvestre HL, Blundell TL, Abell C, Ciulli A. Integrated Biophysical Approach to Fragment Screening and Validation for Fragment-Based Lead Discovery. Proc Natl Acad Sci U S A. 2013; 110:12984-12989. [PubMed: 23872845]

36. Ellman GL. Tissue Sulfhydryl Groups. Arch Biochem Biophys. 1959; 82:70-77. [PubMed: 13650640]

37. NCBI. Inhibition of Glycoprotein Biosynthesis in Gram-Negative Pathogens Inhibitor Probe Project. https://pubchem.ncbi.nlm.nih.gov/bioassay/602402, Deposit Date: 2012-03-15

38. Friesner RA, Murphy RB, Repasky MP, Frye LL, Greenwood JR, Halgren TA, Sanschagrin PC, Mainz DT. Extra Precision Glide: Docking and Scoring Incorporating a Model of Hydrophobic Enclosure for Protein-Ligand Complexes. J Med Chem. 2006; 49:6177-6196. [PubMed: 17034125]

39. James CE, Mahendran KR, Molitor A, Bolla JM, Bessonov AN, Winterhalter M, Pagès JM. How $\beta$-Lactam Antibiotics Enter Bacteria: A Dialogue with the Porins. PLoS ONE. 2009; 4:e5453. [PubMed: 19434239] 
40. Doak BC, Zheng J, Dobritzsch D, Kihlberg J. How Beyond Rule of 5 Drugs and Clinical Candidates Bind to Their Targets. J Med Chem. 2016; 59:2312-2327. [PubMed: 26457449]

41. Hann MM, Keser̈ GM. Finding the Sweet Spot: The Role of Nature and Nurture in Medicinal Chemistry. Nat Rev Drug Discov. 2012; 11:355-365. [PubMed: 22543468]

42. Wan ZK, Wacharasindhu S, Binnun E, Mansour T. An Efficient Direct Amination of Cyclic Amides and Cyclic Ureas. Org Lett. 2006; 8:2425-2428. [PubMed: 16706542]

43. Albe KR, Butler MH, Wright BE. Cellular Concentrations of Enzymes and their Substrates. J Theor Biol. 1990; 22143:163-195.

44. Seidler J, McGovern SL, Doman TN, Shoichet BK. Identification and Prediction of Promiscuous Aggregating Inhibitors among Known Drugs. J Med Chem. 2003; 46:4477-4486. [PubMed: 14521410]

45. Pantoliano MW, Petrella EC, Kwasnoski JD, Lobanov VS, Myslik J, Graf E, Carver T, Asel E, Springer BA, Lane P, Salemme FR. High-Density Miniaturized Thermal Shift Assays as a General Strategy for Drug Discovery. J Biomol Screen. 2001; 6:429-440. [PubMed: 11788061]

46. Wallace AC, Laskowski RA, Thornton JM. LIGPLOT: a program to generate schematic diagrams of protein-ligand interactions. Protein Eng. 1995; 8:127-134. [PubMed: 7630882]

47. Dunford JE, Kwaasi AA, Rogers MJ, Barnett BL, Ebetino FH, Russell RGG, Oppermann U, Kavanagh KL. Structure-Activity Relationships Among the Nitrogen Containing Bisphosphonates in Clinical Use and Other Analogues: Time-Dependent Inhibition of Human Farnesyl Pyrophosphate Synthase. J Med Chem. 2008; 51:2187-2195. [PubMed: 18327899]

48. Morrison MJ, Imperiali B. Biochemical Analysis and Structure Determination of Bacterial Acetyltransferases Responsible for the Biosynthesis of UDP-N,N'-Diacetylbacillosamine. J Biol Chem. 2013; 288:32248-32260. [PubMed: 24064219]

49. Lertpiriyapong K, Gamazon ER, Feng Y, Park DS, Pang J, Botka G, Graffam ME, Ge Z, Fox JG. Campylobacter jejuni Type VI Secretion System: Roles in Adaptation to Deoxycholic Acid, Host Cell Adherence, Invasion, and in vivo Colonization. PLoS ONE. 2012; 7:e42842. [PubMed: 22952616]

50. Isabella, Vincent M., Campbell, Arthur J., Manchester, J., Sylvester, M., Nayar, Asha S., Ferguson, Keith E., Tommasi, R., Miller, Alita A. Toward the Rational Design of Carbapenem Uptake in Pseudomonas aeruginosa. Chem Biol. 2015; 22:535-547. [PubMed: 25910245]

51. Lo AWH, Van de Water K, Gane PJ, Chan AWE, Steadman D, Stevens K, Selwood DL, Waksman G, Remaut H. Suppression of Type 1 Pilus Assembly in Uropathogenic Escherichia coli by Chemical Inhibition of Subunit Polymerization. J Antimicrob Chemother. 2014; 69:1017-1026. [PubMed: 24324225]

52. Adams LA, Sharma P, Mohanty B, Ilyichova OV, Mulcair MD, Williams ML, Gleeson EC, Totsika M, Doak BC, Caria S, Rimmer K, Horne J, Shouldice SR, Vazirani M, Headey SJ, Plumb BR, Martin JL, Heras B, Simpson JS, Scanlon MJ. Application of Fragment-Based Screening to the Design of Inhibitors of Escherichia coli DsbA. Angew Chem Int Ed Engl. 2015; 54:2179-2184. [PubMed: 25556635]

53. Moore JD, Rossi FM, Welsh MA, Nyffeler KE, Blackwell HE. A Comparative Analysis of Synthetic Quorum Sensing Modulators in Pseudomonas aeruginosa: New Insights into Mechanism, Active Efflux Susceptibility, Phenotypic Response, and Next-Generation Ligand Design. J Am Chem Soc. 2015; 137:14626-14639. [PubMed: 26491787]

54. Ménard R, Schoenhofen IC, Tao L, Aubry A, Bouchard P, Reid CW, Lachance P, Twine SM, Fulton KM, Cui Q, Hogues H, Purisima EO, Sulea T, Logan SM. Small-Molecule Inhibitors of the Pseudaminic Acid Biosynthetic Pathway: Targeting Motility as a Key Bacterial Virulence Factor. Antimicrob Agents Chemother. 2014; 58:7430-7440. [PubMed: 25267679]

55. Curtis MM, Russell R, Moreira CG, Adebesin AM, Wang C, Williams NS, Taussig R, Stewart D, Zimmern P, Lu B, Prasad RN, Zhu C, Rasko DA, Huntley JF, Falck JR, Sperandio V. QseC Inhibitors as an Antivirulence Approach for Gram-Negative Pathogens. mBio. 2014; 5:e2165. [PubMed: 25389178]

56. Emsley P, Cowtan K. Coot: Model-Building Tools for Molecular Graphics. Acta Cryst Sect D. 2004; 60:2126-2132. [PubMed: 15572765] 


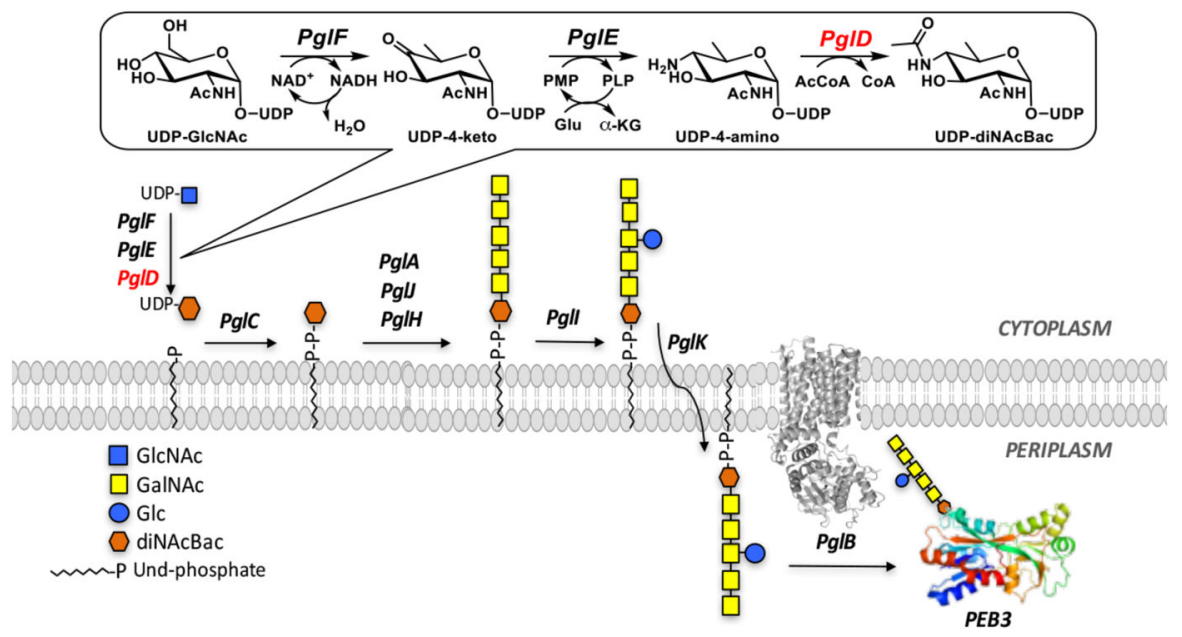

Figure 1.

Schematic representation of the $C$. jejuni $\mathrm{N}$-linked protein glycosylation pathway. Enzymes are shown in italics with the oligosaccharyl transferase PglB shown as determined in PDB 3RCE. Also shown is an N-linked glycosylation substrate PEB3 (PDB: 2HXW), which is a virulence factor in periplasm that is modified by N-linked glycosylation. Inset highlights the three sugar-modifying enzymes that convert UDP-GlcNAc to UDP-diNAcBac. 

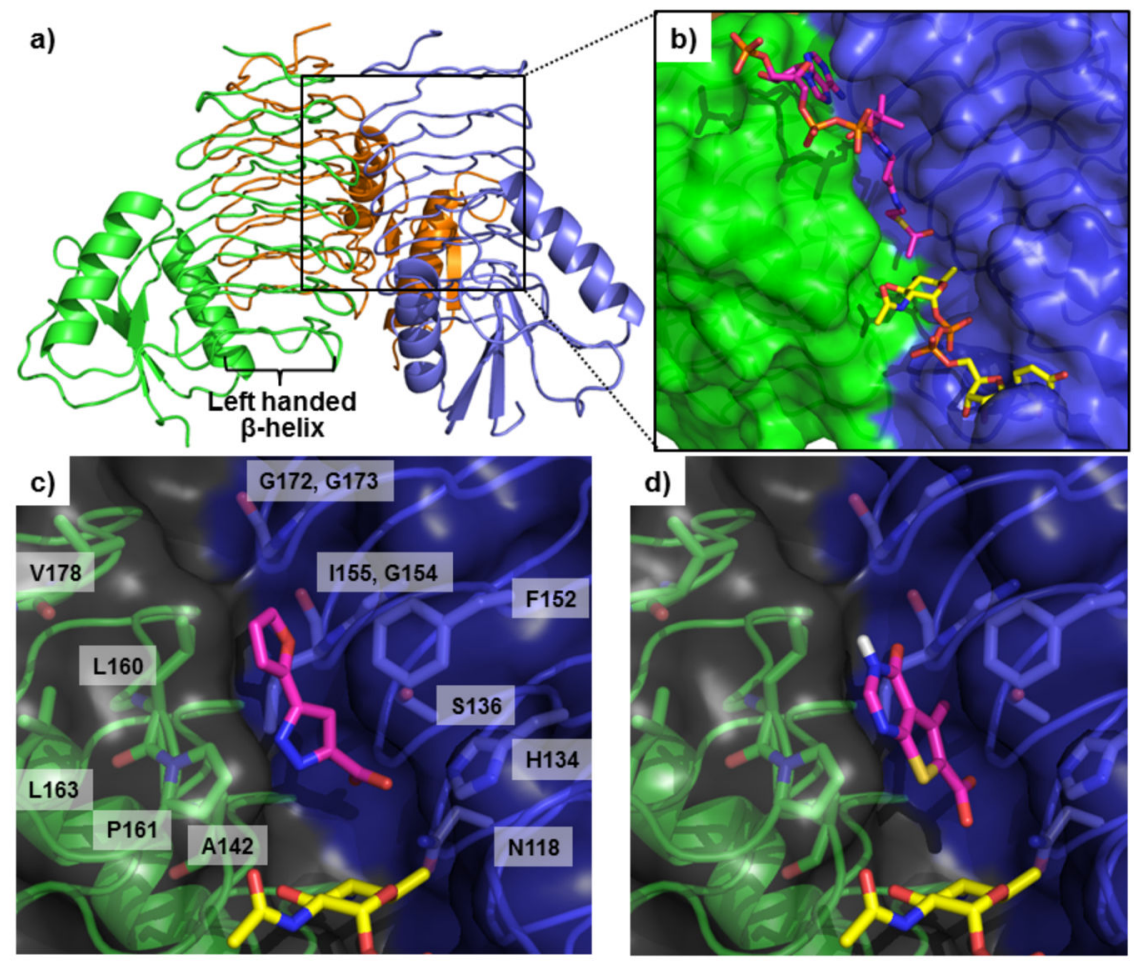

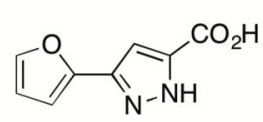

1

$\mathrm{IC}_{50}=8.4 \mathrm{mM}$<smiles>Cc1c(C(=O)O)sc2nc(C(C)C)[nH]c(=O)c12</smiles>

2

$\mathrm{IC}_{50}=122 \mu \mathrm{M}$<smiles>Cc1c(C(=O)O)sc2nc[nH]c(=O)c12</smiles>

3

$I_{50}=860 \mu \mathrm{M}$<smiles>Cc1c(C(=O)O)sc2nc(/C=C/c3ccc4[nH]ccc4c3)[nH]c(=O)c12</smiles>

Figure 2.

Structure analysis of $C$. jejuni PglD. (a) Crystal structure of the PglD homotrimer (PDB 3BSY) in cartoon representation; individual protomers are colored in green, blue and orange. (b) Expanded of view of the PgID active site protein surface with the AcCoA substrate shown in stick representation (magenta, PDB 3BSY) as well as the UDP-4-amino-sugar substrate (yellow, PDB 3BSS). (c) Crystal structure of fragment 1 (magenta) bound to PgID with a semi-transparent surface and selected side-chain residues shown in stick representation and annotated (PDB 5TYH). (d) Docking output pose generated for compound 3 (Glide, Maestro). ${ }^{38}$ 

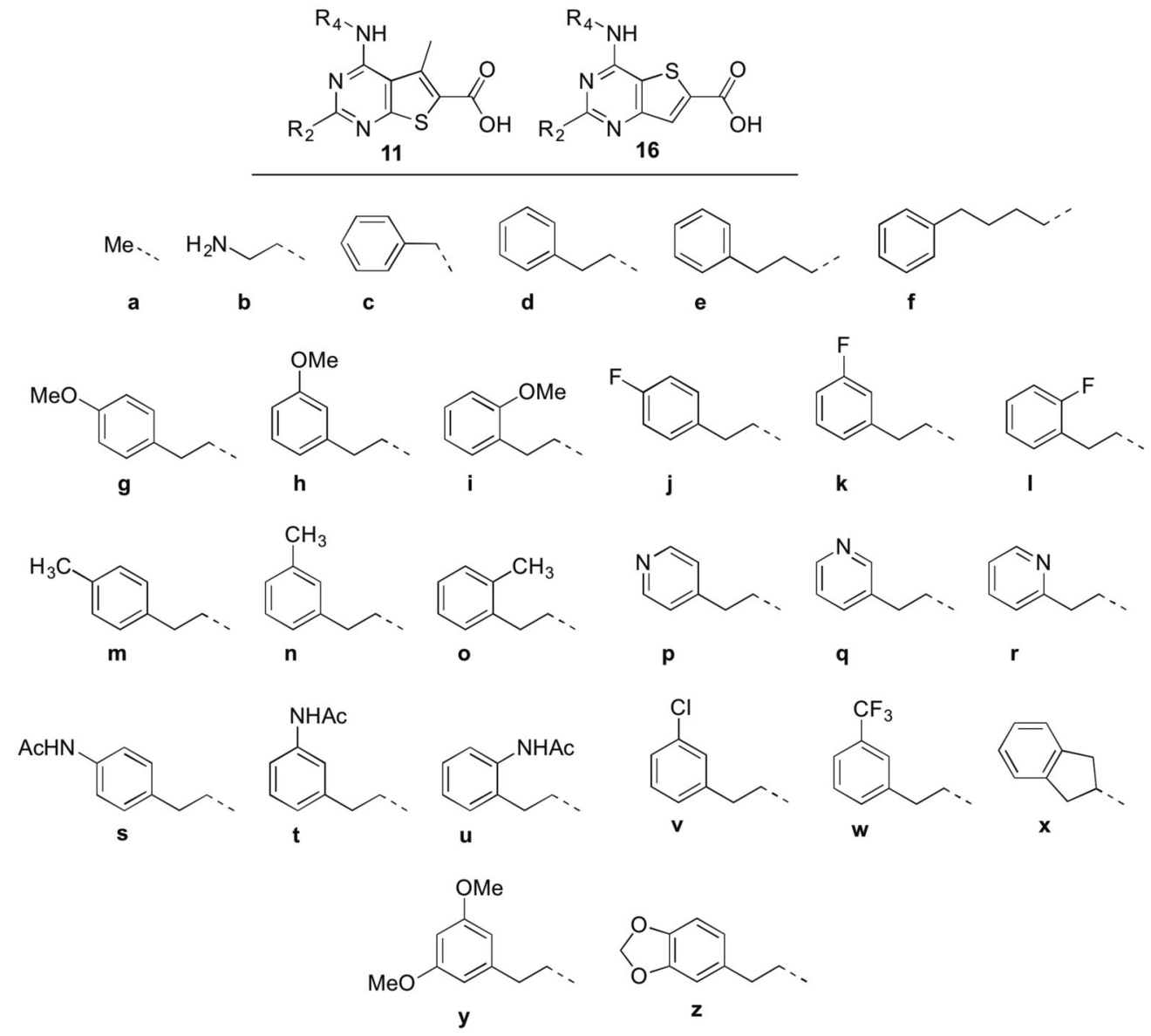

Figure 3.

Representative examples of thienopyrimidine-6-carboxylate inhibitors of $C$. jejuni PglD;

Core 11: $R_{2}=\mathbf{a}-\mathbf{z} ; R_{4}=\mathbf{a}-\mathbf{z} ;$ Core 16: $R_{2}=\mathbf{d}, \mathbf{h} ; R_{4}=\mathbf{a}$. 

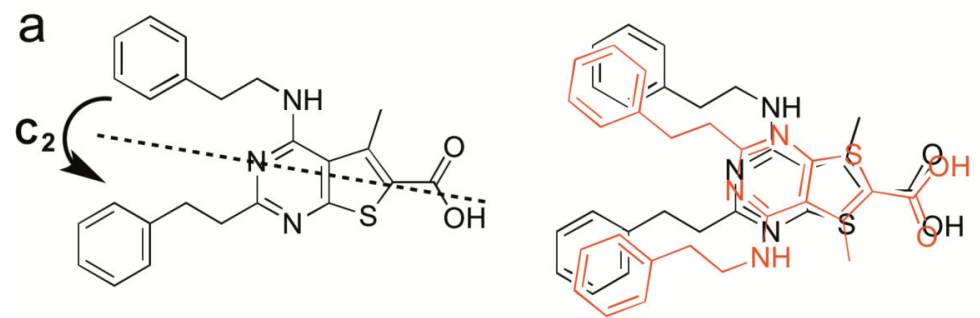

b
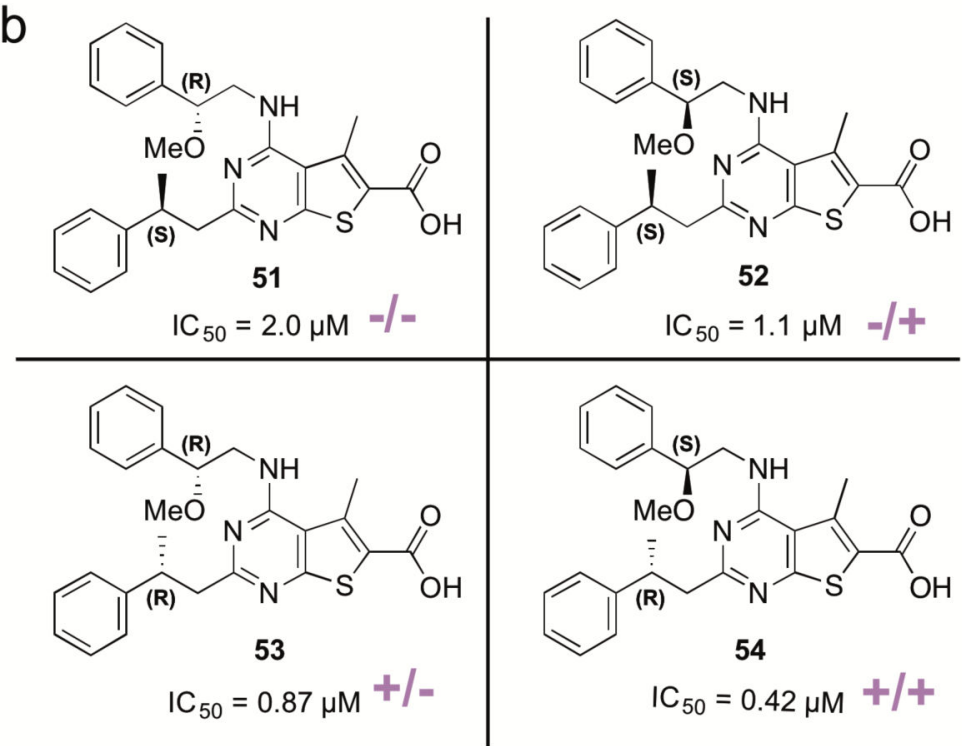

Figure 4.

(a) Illustration of the quasi $\mathrm{C}_{2}$ symmetry axis of the disubstituted inhibitors (b) SAR of inhibitors 51 - 54 with rigidified $R_{2}$ and $R_{4}$ substituents; magenta symbols represent stereochemical preference of $\mathrm{R}_{2}$ and $\mathrm{R}_{4}$ substituents with respect to the PgID protein surface and highlight the mismatched/matched pattern. 

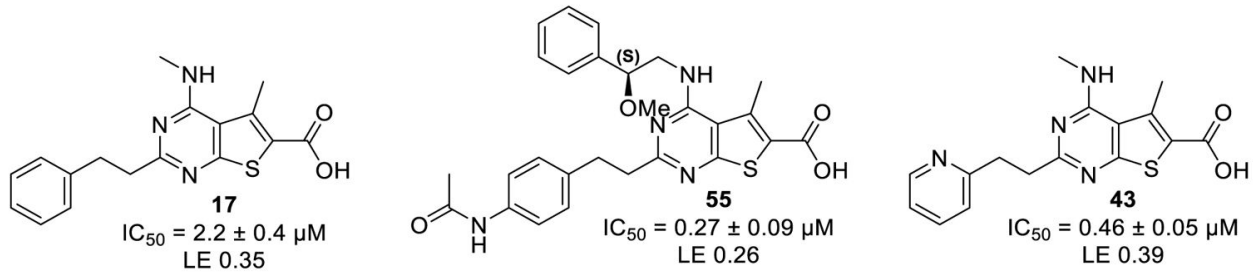

Figure 5.

Structures of key inhibitors discussed in this section: 17, $\mathbf{4 3}$ and $\mathbf{5 5}$. 


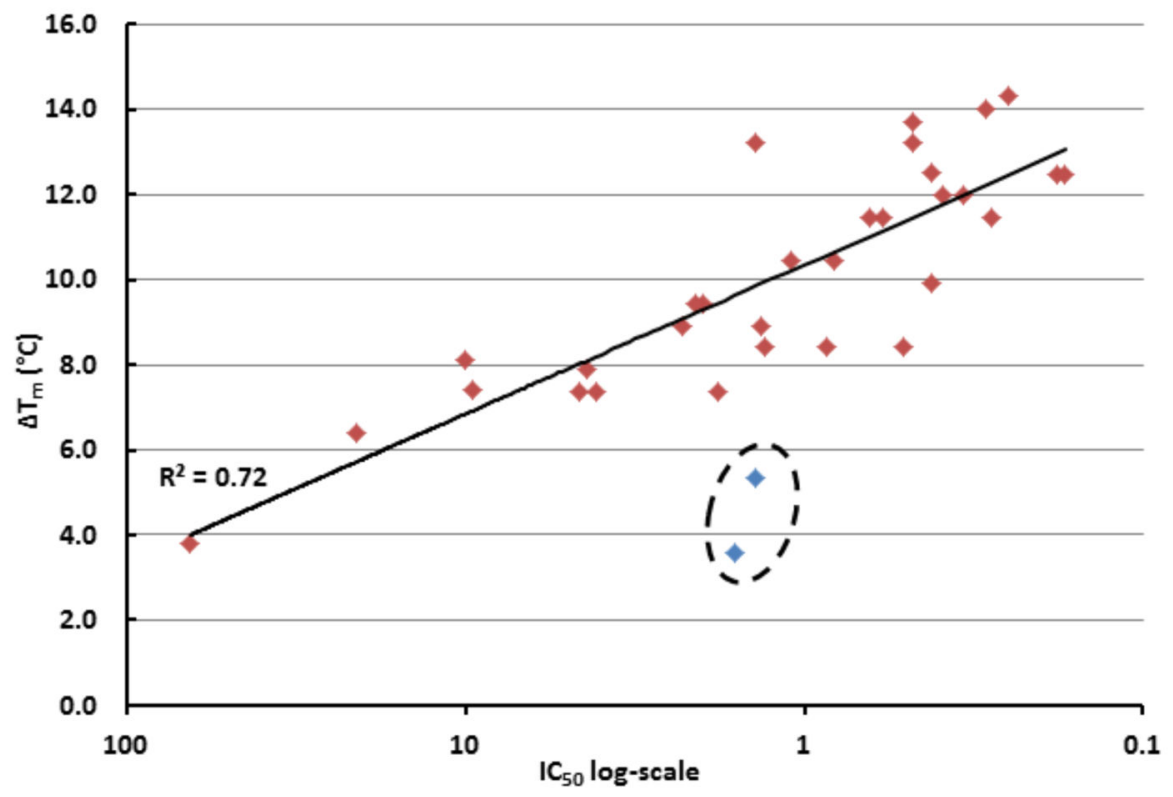

Figure 6.

Correlation between the in vitro potency against PglD and the $\mathrm{T}_{\mathrm{m}}$ (calculated from the first derivative of the thermal melting curve) of the PgID/inhibitor complexes with core 11; thermal melt assays were performed with $10 \mu \mathrm{M}$ PglD and $100 \mu \mathrm{M}$ compound. Correlation coefficient provided for all data indicated by red diamond. Inhibitors with $\mathrm{R}_{4}=\mathbf{b}$ (ethylamine) (blue diamond, circled) appear as outliers and are omitted from the calculation of the correlation coefficient. 

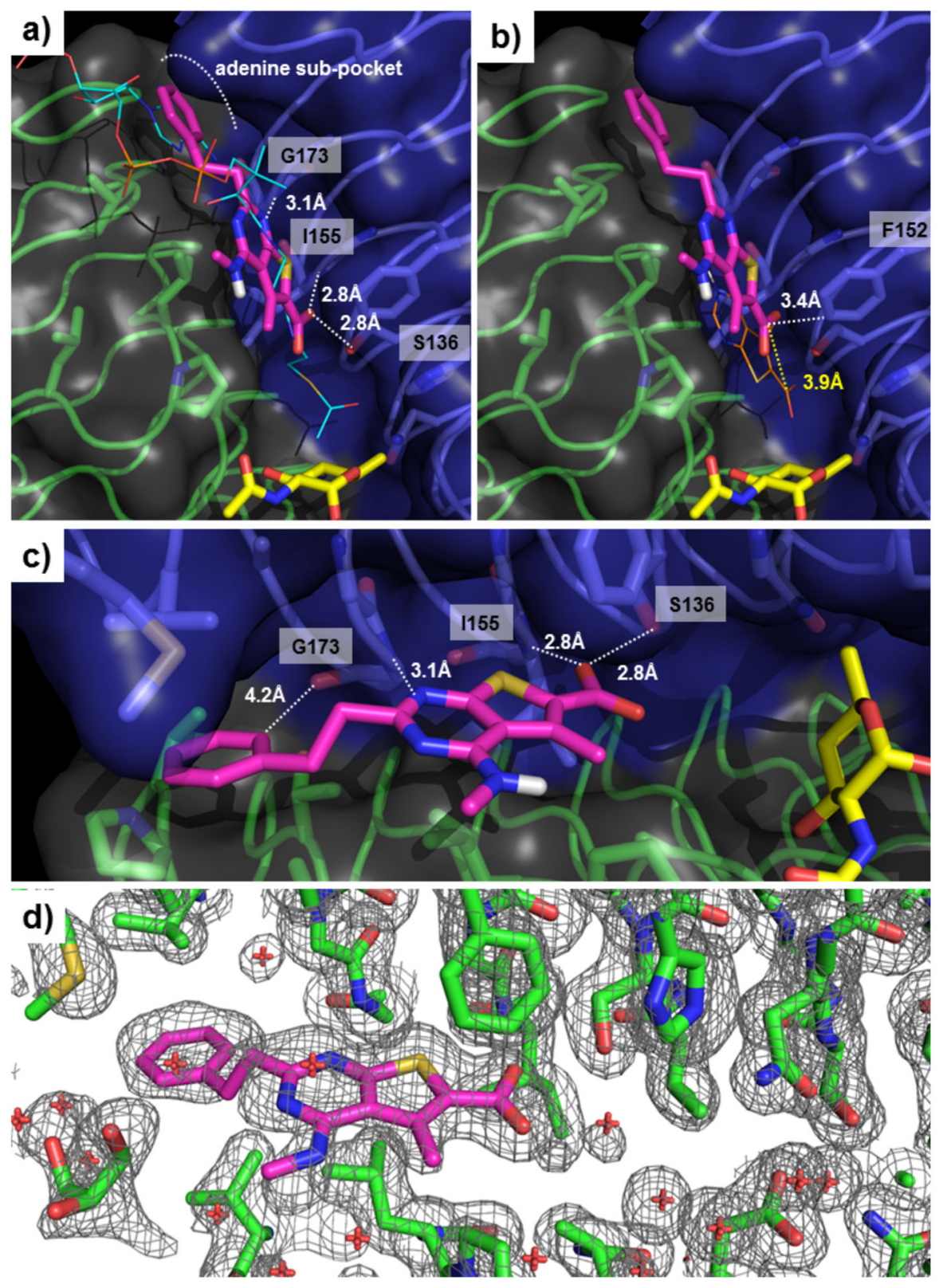

Figure 7.

Co-crystal structure of the PglD/17 complex (PDB 5T2Y). (a) Inhibitor 17 shown in sticks presentation (magenta) and overlayed with AcCoA substrate in lines (cyan, PDB 3BSY) and sugar substrate in sticks (yellow, PDB 3BSS). (b) overlay with the computational docking pose of compound $\mathbf{2}$ in line representation (orange). (c) Side-view highlighting the AcCoA adenine sub-pocket and interaction between 17 and residues Gly173, Ile155 and Ser136. White dashed lines indicate distances between $\mathbf{1 7}$ and PgID side-chain residues; yellow dashed line shows distance between the carboxylate computational docking pose and crystal structure. (d) Composite omit map $2 \mathrm{~F}_{\mathrm{o}}-\mathrm{F}_{\mathrm{c}}$ contoured at $1.0 \sigma$ generated with the built in functionality of the PHENIX software and image generated in PYMOL. 


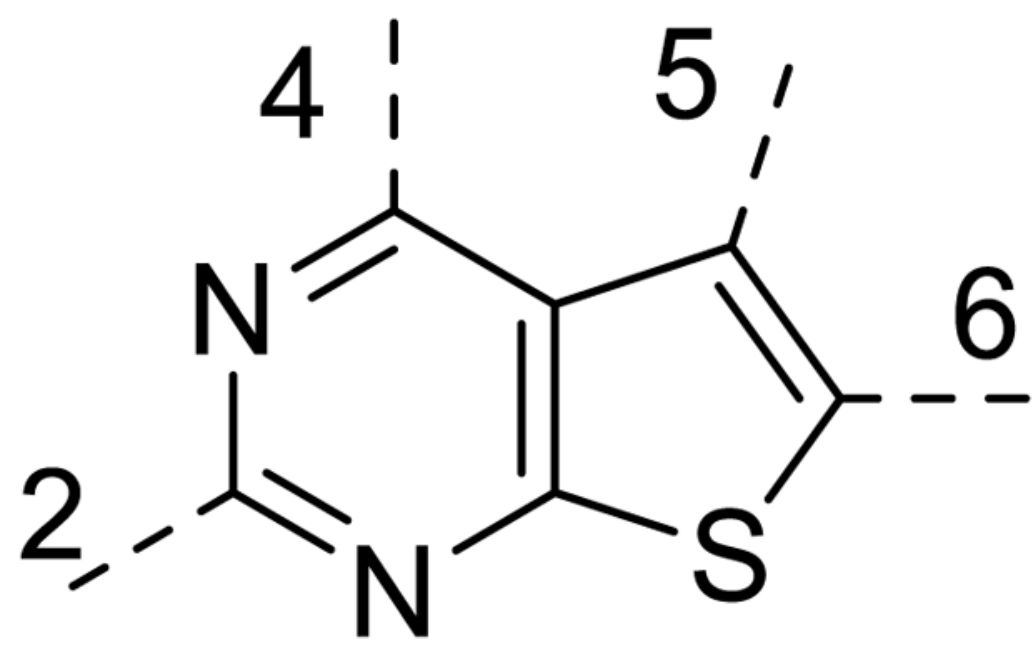

Scheme 1.

General structure and numbering system of the thienopyrimidine core. 


\section{Route I}<smiles>[R]Nc1nc([R2])nc2sc(C(=O)OCC)c(C)c12</smiles><smiles>[R9]Nc1nc(CC[Al])nc2sc(C(=O)OCC)c(C)c12</smiles><smiles>[R2]Nc1nc([R2])nc2sc(C(=O)O)c(C)c12</smiles>

Scheme 2.

Synthesis of inhibitors with thienopyrimidine-6-carboxylate core $\mathbf{1 1}$ Conditions: (a) 1.2 equiv. $\mathrm{R}_{2} \mathrm{CN}, 4 \mathrm{M} \mathrm{HCl}$ in 1,4-dioxane, $90^{\circ} \mathrm{C}$ (50-90\%); (b) 1.5 equiv. $\mathrm{R}_{4} \mathrm{NH}_{2}, 1.3$ equiv. PyBOP, 3 equiv. DBU, $\mathrm{MeCN}$, RT (40-90\%); (c) 1.2 equiv. $\mathrm{ClCH}_{2} \mathrm{CN}, 4$ $\mathrm{M} \mathrm{HCl}$ in 1,4-dioxane, $90^{\circ} \mathrm{C}(50-90 \%)$ (d) 20 equiv. $\mathrm{P}(\mathrm{OEt})_{3}, 145^{\circ} \mathrm{C}(85 \%)$; (e) 1.5 equiv. $\mathrm{NaH}, 2$ equiv. ArCHO, THF, RT (70-90\%); (f) $10 \% \mathrm{Pd}(\mathrm{OH})_{2} / \mathrm{C}$, THF/MeOH 1:1, $60^{\circ} \mathrm{C}$ (quant.); (g) 1.5 equiv. $\mathrm{R}_{4} \mathrm{NH}_{2}, 1.3$ equiv. PyBOP, 3 equiv. $\mathrm{DBU}$, MeCN, RT (40-90\%) (h) 3 equiv. $\mathrm{NaOH}, \mathrm{THF} / \mathrm{MeOH} / \mathrm{H}_{2} \mathrm{O}$ 2:1:1, RT (50-80\%). 

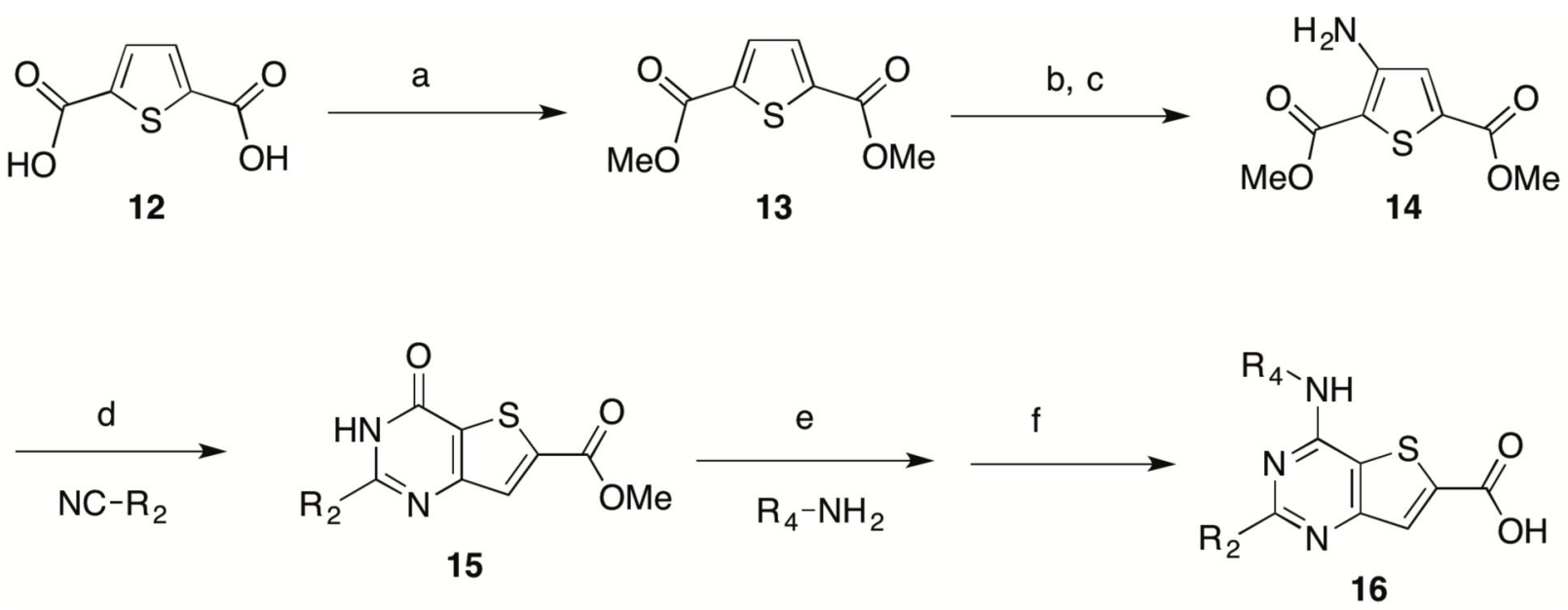

Scheme 3 .

Synthesis of inhibitors with thienopyrimidine-6-carboxylate core 16 Conditions: (a) 4 equiv. $\mathrm{SOCl}_{2}, \mathrm{MeOH}, 50^{\circ} \mathrm{C}$ (99\%); (b) 2 equiv. $\mathrm{HNO}_{3}, \mathrm{H}_{2} \mathrm{SO}_{4}$, $\mathrm{RT}$; (c) $10 \% \mathrm{Pd}(\mathrm{OH})_{2} / \mathrm{C}, \mathrm{THF} / \mathrm{MeOH} 1: 1$, RT (93\% over 2 steps); (d) 1.2 equiv. $\mathrm{R}_{2} \mathrm{CN}, 4 \mathrm{M} \mathrm{HCl}$ in 1,4-dioxane, $90^{\circ} \mathrm{C}(60-80 \%)$; (e) 1.5 equiv. $\mathrm{R}_{4} \mathrm{NH}_{2}, 1.3$ equiv. PyBOP, 3 equiv. DBU, $\mathrm{MeCN}, \mathrm{RT}$ (40-90\%); (f) 3 equiv. $\mathrm{NaOH}$ in THF/MeOH/H $2 \mathrm{O}$ 2:1:1, RT (50-80\%). 


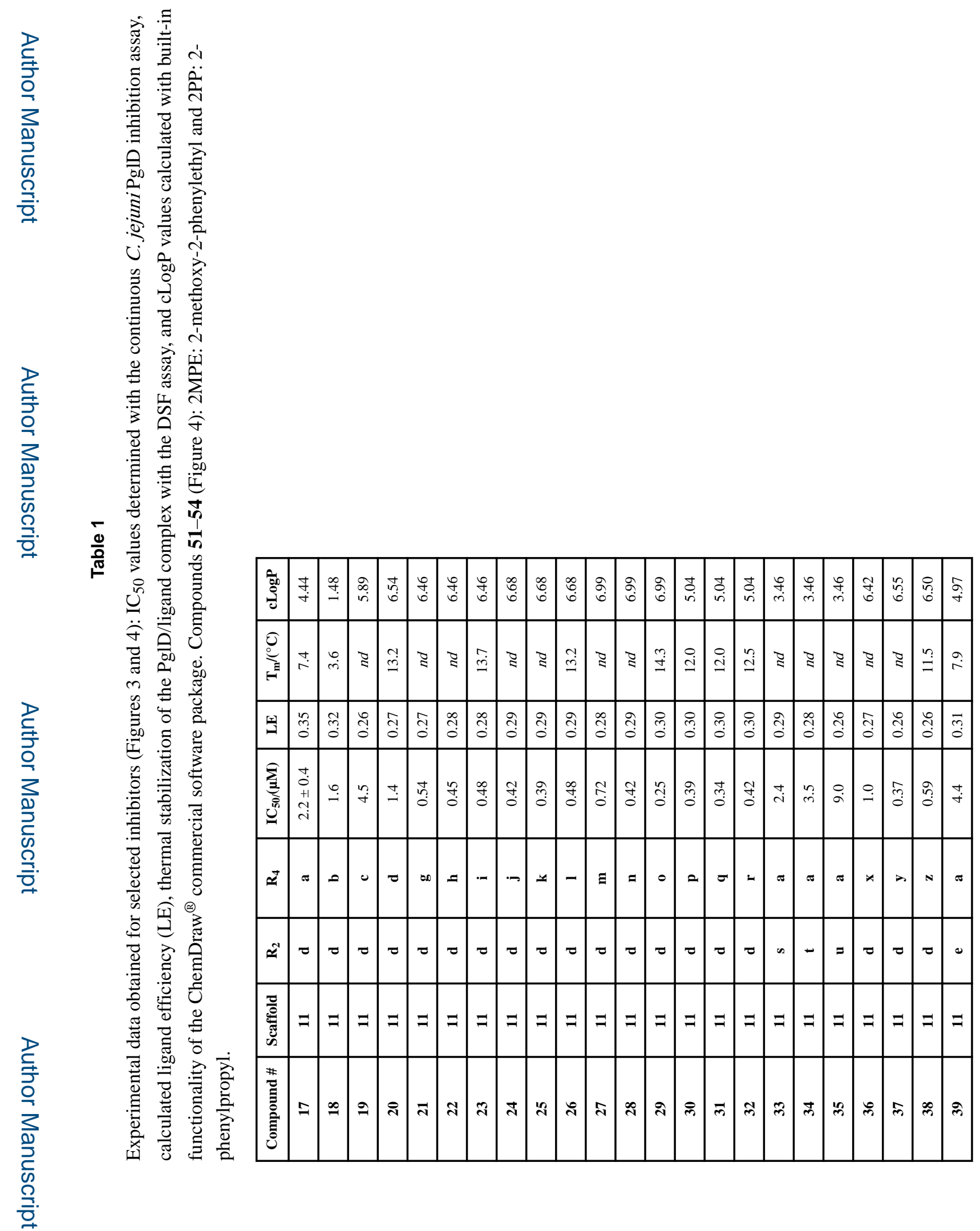




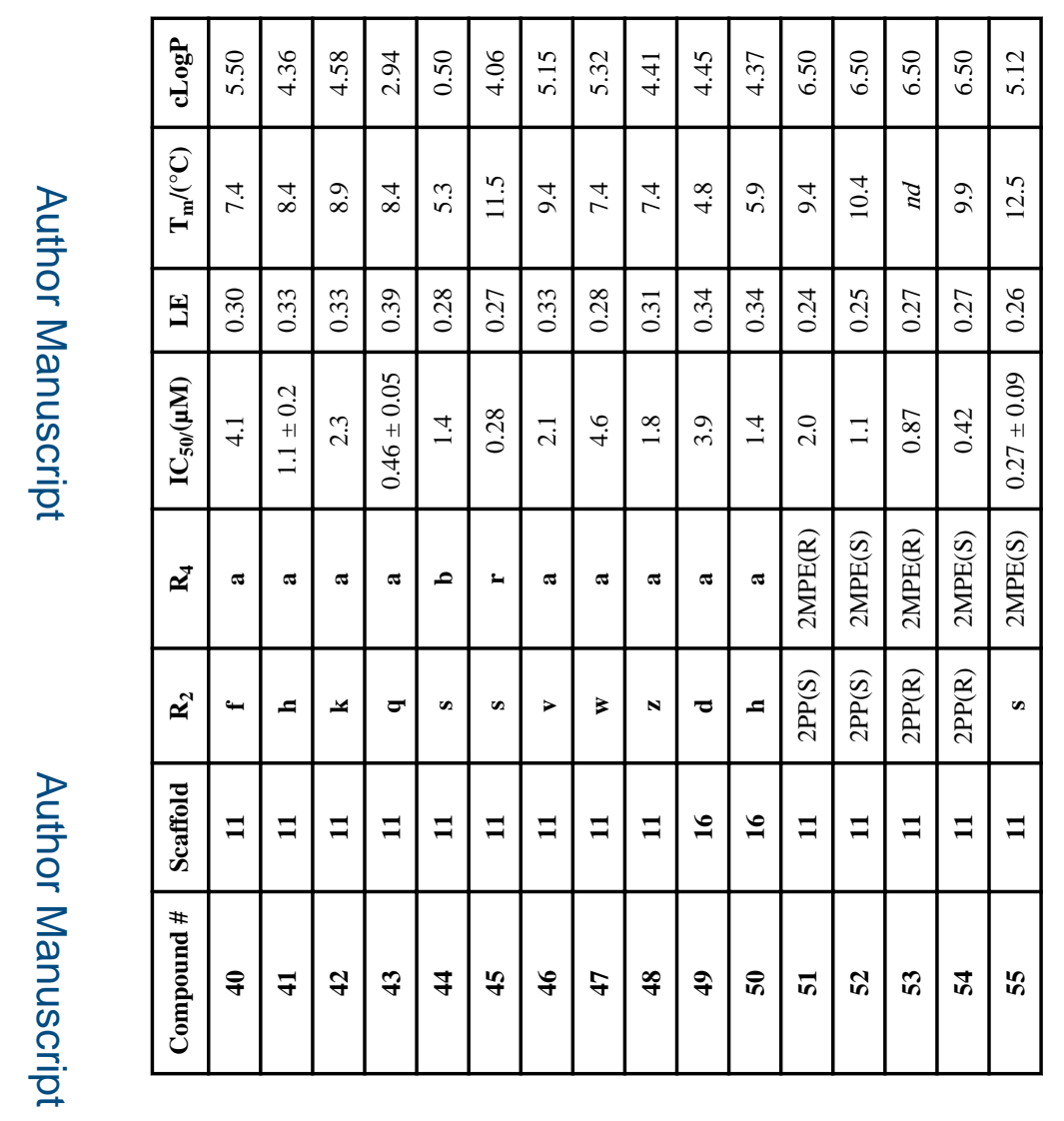

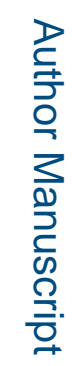

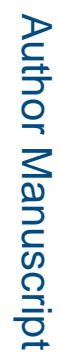

